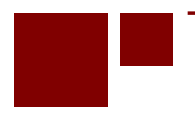

C E N T E R for RETIREMENT RES E A R C H at BOSTON COLLEGE

\title{
RETIREMENT PROSPECTS FOR THE MILLENNIALS: WHAT IS THE EARLY PROGNOSIS?
}

\author{
Richard W. Johnson, Karen E. Smith, Damir Cosic, and Claire Xiaozhi Wang
}

CRR WP 2017-17

November 2017

Center for Retirement Research at Boston College

Hovey House

140 Commonwealth Avenue

Chestnut Hill, MA 02467

Tel: 617-552-1762 Fax: 617-552-0191

http://crr.bc.edu

Richard W. Johnson and Karen E. Smith are senior fellows at the Urban Institute. Damir Cosic is a research associate and Claire Xiaozhi Wang is a research assistant at the Urban Institute. The research reported herein was pursuant to a grant from the U.S. Social Security Administration (SSA) funded as part of the Retirement Research Consortium. The findings and conclusions expressed are solely those of the authors and do not represent the views of SSA, any agency of the federal government, the Urban Institute, or Boston College.

(C) 2017, Richard W. Johnson, Karen E. Smith, Damir Cosic, and Claire Xiaozhi Wang. All rights reserved. Short sections of text, not to exceed two paragraphs, may be quoted without explicit permission provided that full credit, including $₫$ notice, is given to the source. 


\begin{abstract}
About the Center for Retirement Research
The Center for Retirement Research at Boston College, part of a consortium that includes parallel centers at the University of Michigan and the National Bureau of Economic Research, was established in 1998 through a grant from the Social Security Administration. The Center's mission is to produce first-class research and forge a strong link between the academic community and decision-makers in the public and private sectors around an issue of critical importance to the nation's future. To achieve this mission, the Center sponsors a wide variety of research projects, transmits new findings to a broad audience, trains new scholars, and broadens access to valuable data sources.
\end{abstract}

Center for Retirement Research at Boston College

Hovey House

140 Commonwealth Ave

Chestnut Hill, MA 02467

Tel: 617-552-1762 Fax: 617-552-0191

http://crr.bc.edu

Affiliated Institutions:

The Brookings Institution

Syracuse University

Urban Institute 


\begin{abstract}
Various policy developments and long-term economic, social, and demographic trends raise worrisome questions about the financial security of future retirees. An erosion in employer-sponsored defined benefit pension coverage and the increase in Social Security's full retirement age could shrink future benefits. Stagnating employment and earnings for men could threaten future retirement security, because retirement benefits and the capacity to save depend on lifetime earnings. The financial crisis, Great Recession, and collapse of the housing market in the second half of the previous decade could significantly disrupt retirement savings. This paper assesses retirement prospects for future generations, with a special focus on the late Generation$\mathrm{X}$ and the Millennial generations. Because retirement outcomes depend on how much people earned and saved when they were younger, the analysis compares trends in employment, earnings, pension coverage, and wealth during working ages across cohorts, using data from the Current Population Survey and the Survey of Consumer Finances. The analysis also projects age-70 incomes for future generations using DYNASIM4, the Urban Institute’s dynamic microsimulation model.
\end{abstract}

This paper found that:

- Many recent trends threaten future retirement security, including continuing declines in men’s employment before age 55, stagnating median earnings for men, and a sharp decline in median household wealth after 2007.

- Other trends are more encouraging. Gen-X and Millennial women worked and earned more in their 20s and 30s than now-retired women did at those ages, and Millennial men and women are much more likely to have a four-year college degree than previous cohorts.

- Projections show that median age-70 income will be higher for Gen-Xers and Millennials than previous generations as earnings grow over time.

- However, a larger share of retired Gen-Xers and Millennials will be unable to replace at least three-quarters of their pre-retirement earnings, according to the projections, and will see their living standards decline when they retire. 
The policy implications of this paper are:

- How employment, earnings, and savings patterns evolve over the next three decades will shape Millennials’ retirement incomes.

- Policy choices regarding retirement programs, especially strategies to address Social Security’s long-term financing gap, will significantly affect the retirement security of future generations. 


\section{Introduction}

Changes in retirement programs and ongoing economic, social, and health-care-related trends raise worrisome questions about the financial security of future retirees. The increase in Social Security's full retirement age will reduce benefits for workers who retire in the future, and the system's long-term financing problems could lead to additional benefit cuts in two decades unless Congress addresses the funding shortfall. Private-sector employers have moved away from defined benefit (DB) pensions to defined contribution (DC) retirement plans over the past three decades, shifting much of the responsibility for retirement saving from employers to employees and reducing future retirement benefits for many workers (Morrissey, 2016; Munnell, 2014). Falling labor supply among middle-aged men (Council of Economic Advisers, 2016) and stagnant earnings for lower- and moderate-income men (Mishel, 2015) threaten future retirement security, because Social Security benefits and the capacity to save for retirement depend on lifetime earnings. Future retirees will need more money than earlier generations as health care costs and indebtedness rise (Hatfield et al., 2016; Karamcheva, 2016), and retirement savings must last longer as retirees’ life expectancy grows.

The financial crisis, Great Recession, and collapse of the housing market in the second half of the previous decade led to unusually high and long-lasting unemployment and wiped out trillions of dollars of household wealth (Grusky, Western, and Wimer, 2011; Smeeding, 2012; Wolff, 2016). Lost earnings and wealth can derail retirement savings. The recession hit younger workers especially hard. They were more likely to lose their jobs than older workers (Farber, 2015), and the economic consequences of a layoff can persist for decades, leading to lower earnings on future jobs (Davis and Van Wachter, 2011). Moreover, people who graduate from college during a recession often have trouble finding a good job, suppressing their earnings for years (Oreopoulos, von Wachter, and Heisz, 2012). Consequently, the Great Recession could significantly disrupt retirement savings for people born in the late 1970s and early 1980s, who were in their 20s during the early part of this decade. On the other hand, relatively few younger people own a home or hold much wealth, so the collapse in housing and equity prices in the wake of the financial crisis probably did not affect them as much as it affected older people.

Other economic and demographic trends, however, are more encouraging. Women who retire in coming decades will have worked in paid employment more and earned more than previous generations (Goldin and Mitchell, 2017), enabling then to accumulate more Social 
Security benefits and retirement savings in their own names. Increases in the national average wage raises Social Security payments for all beneficiaries, even for those with relatively low earnings. Widows are especially likely to be impoverished (Sevak, Weir, and Willis, 2003/2004), but the shrinking gender gap in life expectancy (Trovato and Heyen, 2006) will reduce future widowhood rates. In addition, people are working longer than previous generations (Johnson and Wang, 2017), raising their lifetime earnings, future Social Security benefits, and capacity to save for retirement.

Given these conflicting trends, it is perhaps not surprising that there is no consensus about how future generations will likely fare in retirement. Several studies warn of a looming retirement crisis, predicting that in coming decades many older adults will live in or near poverty and a majority will be unable to maintain their preretirement living standards (Munnell, Hou, and Webb, 2014; Rhee, 2013). Other studies are more sanguine, concluding that most people are saving adequately and that economic growth will boost future retirement incomes (Biggs and Schieber, 2014; Butrica, Smith, and Iams, 2012; Scholz, Seshadri, and Khitatrakun, 2006).

This report used household survey data from the past five decades and a dynamic microsimulation model to assess retirement prospects for future generations, with a special focus on the late Gen-X and Millennial generations. Because retirement outcomes depend on how much people earned and saved when they were younger, much of our analysis compared trends in employment, earnings, pension coverage, and wealth during working ages across cohorts. We projected future incomes at age 70, accounting for working-age outcomes that have already occurred. The analysis focused on outcomes for adults born between 1976 and 1980, who we labeled late Gen-Xers, and adults born between 1981 and 1990, the early Millennials. We excluded from our analysis Millennials born after 1990, because their labor market experience is too thin to draw firm conclusions about their long-term earnings potential and capacity to save for retirement. We compared outcomes for these cohorts to those born earlier, including preboomers (born before 1946), early boomers (born between 1946 and 1955), and late boomers (born between 1956 and 1965).

Our results suggest retirement security for late Gen-Xers and Millennials will be shaped by many of the same forces that are already beginning to buffet the financial security of current retirees, including the erosion of DB pension plans and rising debt levels. So far, outcomes for Millennials are not dramatically worse than those for previous recent cohorts, although the 
steady generational improvement in economic status that defined American society in the middle of the twentieth century appears to have ended, at least for now. Men's labor force participation rates continue to decline before age 55 and their median wage remains stagnant. Gen-X and Millennial women are earning more than the Boomers did, but Millennials are not earning more than Gen-Xers. People born after 1970 are not accumulating household wealth any faster than those born in the 1960s, reversing the generational growth experienced by earlier cohorts, and Millennials are less likely to own a home than earlier generations. However, the collapse in home prices and the stock market in the late 2000s complicate these generational comparisons. The most encouraging development for Millennials is the growth in college graduation rates, which raises their future earnings potential.

Our projections show that median age-70 income will be higher for Gen-Xers and Millennials than previous generations, but a greater share may experience falling living standards when they stop working. Using a measure of retirement income that includes payouts that could be collected from an actuarially fair annuity valued at 80 percent of a retiree's financial assets and retirement accounts, we found that 40 percent of 70-year-olds born between 1976 and 1985 would be unable to replace at least 75 percent of the inflation-adjusted average annual earnings

they and their spouse received from ages 50 to 54, under the assumption that average wages grow at the same rate as they did between 1966 and 2015. By comparison, replacement rates at age 70 would likely fall short of the 75 percent threshold for 32 percent of those born between 1936 and 1945 and for 30 percent of those born between 1956 and 1965.

\section{Data and Methods}

To assess retirement prospects for people born in the 1980s and late 1970s, we compared employment, earnings, pension coverage, and household wealth at younger ages for several generations, using household survey data. We also compared projections of retirement incomes for different birth cohorts, generated by our dynamic microsimulation model. Our tabulations report all financial amounts in constant 2015 dollars, adjusted by the change in the consumer price index. 


\section{Measuring Recent Economic Trends before Retirement}

We used household survey data spanning several decades from the Current Population Survey's (CPS) Annual Social and Economic (ASEC) supplement and the Survey of Consumer

Finances (SCF) to examine long-term trends in demographic and economic outcomes. Although the surveys do not follow the same sample of households over time, we created synthetic cohorts by combining information from interviews completed in various years by respondents born in the same period. We then compared aggregate outcomes across cohorts at various ages. When comparing outcomes across cohorts, however, we must recognize the sometimes-substantial differences in macroeconomic conditions, such as the unemployment rate and typical investment returns, that confronted each generation at particular ages. For example, high unemployment rates and slow wage growth during and immediately after the Great Recession and the collapse in housing and equity values in 2007 and 2008 complicate cohort analysis. All estimates were computed at the individual level, not the household level.

The CPS is a monthly survey of about 60,000 households conducted by the U.S. Census Bureau for the Bureau of Labor Statistics (BLS) that collects demographic and employment data. Every March the ASEC collects additional information from CPS respondents on income received during the previous year, employer-sponsored retirement plans during the previous year, and homeownership. With CPS/ASEC data from 1966, 1971, 1976, 1981, 1986, 1991, 1996, 2001, 2006, 2011, and 2016, we created synthetic five-year cohorts for the birth years 1931 to 1935 through 1986 to 1990 . Members of our youngest cohort were ages 26 to 30 in 2016, and members of our oldest cohort were ages 31 to 35 in 1966. We accessed CPS data through the Integrated Public Use Microdata Series (Ruggles et al., 2015).

We used CPS/ASEC data to examine trends in educational attainment, labor force participation, full-time employment, marriage rates, homeownership rates, and, for full-time workers, median earnings and participation rates in employer-sponsored retirement plans. Fulltime employment, earnings, and pension coverage data in the CPS/ASEC refer to outcomes in the previous year, so our cohorts are one year younger for those comparisons. We defined fulltime employment as working at least 35 hours per week. Data on homeownership were not available before 1976 and data on employment-based retirement plans were not available before 1980. When computing homeownership rates, we counted only household heads and their spouses as homeowners if the owner occupied the home; other people living in an owner- 
occupied home were classified as non-homeowners. The analysis generally examined outcomes separately for men and women. Results are reported graphically in the body of the report, but the figures exclude certain cohorts to improve readability. Appendix tables report results for all cohorts.

We used data from the Survey of Consumer Finances (SCF) to examine trends in household wealth levels. The SCF is a national, cross-sectional survey of U.S. families that began in 1983. Sponsored by the Federal Reserve Board and conducted by NORC at the University of Chicago since 1992, the SCF is widely regarded as the premier data source on household wealth (Czajka, Jacobson, and Cody, 2003). Every three years, it interviewed between 4,500 and 6,500 families covering all economic strata. Sampling began with a geographically based random sample, which was then supplemented with a sample of disproportionally wealthy families to reflect ownership of certain assets. Our sample included only household heads and their spouses, if married. For married people, we divided reported household wealth by two. Following the approach we used with the CPS/ASEC, we grouped respondents into six-year birth cohorts-from the 1928 to 1933 cohort through the 1976 to 1981 cohort-and measured their wealth every six years, in 1989, 1995, 2001, 2007, and 2013, the most recent year available when we completed our analysis. This approach allowed us to compare household wealth at the same age for people born in different years. Members of our youngest SCF cohort were ages 32 to 37 in 2013, and members of our oldest cohort were ages 56 to 61 in 1989. Because our SCF analysis included only household heads and their spouses, young adults who were still living with their parents were excluded. Because people who recently entered adulthood are leaving home and starting their own households later than previous generations (Furlong, 2016; Lee and Painter, 2013), our SCF sample of younger adults might include a disproportionate share of relatively successful people who have already started their own households, biasing our wealth estimates upwards.

The financial measures we examined were total net worth, retirement account balances, financial wealth (including retirement account balances), housing wealth, and debt. Retirement account balances included the value of individual retirement accounts (IRAs), Keogh accounts, and employer-sponsored retirement accounts, such as 401(k) plans. Financial wealth consisted of retirement account balances plus financial assets held outside of retirement accounts, including the value of bank accounts, certificates of deposit, annuities, trusts, stocks, bonds, 
mutual funds, and the cash value of life insurance. We measured housing wealth as the gross value of a primary home. Debt included housing debt, outstanding installment loans, outstanding credit card balances, and any other debt held by a household. Total net worth equaled the sum of financial wealth, housing wealth, and other nonfinancial wealth (which included the value of vehicles, business interests, real estate except for a primary home, and other real assets), minus debt.

\section{Projecting Retirement Outcomes}

To project future retirement income, we used DYNASIM4, a dynamic microsimulation model designed to analyze the long-run distributional consequences of retirement and aging issues. The model starts with a representative sample of individuals and families from the 2004 and 2008 Survey of Income and Program Participation (SIPP) and ages them year by year, simulating key demographic, economic, and health events. For example, DYNASIM4 projects that, each year, some people in the sample get married, have a child, or find a job. The model projects that other people become divorced or widowed, stop working, begin collecting Social Security, become disabled, or die. These transitions are based on probabilities generated by carefully calibrated equations estimated from nationally representative household survey data. The equations account for important differences by sex, education, earnings, and other characteristics in the likelihood of various experiences. Other equations in DYNASIM4 project annual earnings, savings, and home values. The model uses program rules-combined with projections of lifetime earnings, disability status, and household income and wealth — to project Social Security retirement and disability benefits and Medicaid coverage. For consistency with Social Security's projections about system finances, we generally use the same assumptions as the Social Security and Medicare trustees. The appendix describes in more detail how DYNASIM projects economic outcomes. For more information about DYNASIM, see Urban Institute (2015) and Favreault, Smith, and Johnson (2015).

Using DYNASIM4, we projected outcomes for five 10-year birth cohorts: 1936 to 1945 (pre-boomers), 1946 to 1955 (early boomers), 1956 to 1965 (late boomers), 1966 to 1975 (GenX), and 1976 to 1985 (late Gen-X, early Millennials). The analysis compared inflation-adjusted income levels and retirement replacement rates at age 70. We focused on incomes at age 70 because most people have stopped working by then, but 70-year-olds are not so old that 
socioeconomic differentials in mortality rates could substantially bias our estimates.

Replacement rates were computed by dividing age-70 income by average annual earnings received from ages 50 to 54, both expressed in inflation-adjusted dollars. We divided family income by two for married adults to create a per capita measure.

We compared two measures of median annual per capita family income at age 70 . The traditional income measure counted cash income (earnings, Social Security, DB pensions, Supplemental Security Income, interest, dividends, and rent), plus money withdrawn from retirement accounts (based on historic withdrawal trends and required minimum distributions). The alternative total potential income measure accounted for the shift away from DB pensions to DC retirement accounts by adding to cash income the income stream that retirees would receive if they annuitized 80 percent of their retirement accounts and other financial assets under actuarially fair terms. Because relatively few retirees annuitize their assets and many do not spend much of their wealth (Lockwood, 2012; Smith, Soto, and Penner, 2009), we examined both income measures. Each measure used Social Security benefits scheduled under current law, even though Social Security projects that it will be able to finance those benefits under existing revenue forecasts only until 2034 (Board of Trustees, Federal Old-Age and Survivors Insurance and Federal Disability Insurance Trust Funds, 2017), before late Gen-Xers and Millennials reach age 70 .

Future retirement income for late Gen-Xers and Millennials depends on how fast average wages grow over the next three or four decades. The Social Security trustees assume that real wages grow 1.2 percent per year in the long term (Board of Trustees, Federal Old-Age and Survivors Insurance and Federal Disability Insurance Trust Funds, 2017), much faster than actual growth over the past half century. Real annual wage growth averaged 0.81 percent between 1966 and 2015 and only 0.70 percent between 1973 and 2015, which excluded the high-growth period from 1966 to 1973. Because of the uncertainty surrounding future wage growth, we projected retirement income under three scenarios-a high-wage-growth scenario that assumed real wages grow 1.2 percent per year, a moderate-wage-growth scenario that assumed real wages grow 0.81 percent per year, and a low-wage-growth scenario that assumed real wages grow 0.70 percent per year. 


\section{Results}

We first report cohort comparisons for preretirement outcomes, based on historical data from the ASEC/CPS and SCF. We then report retirement income projections from DYNASIM4.

\section{Education}

Men's educational attainment surged with the early Baby Boomers and then tapered off for men born in the 1950s and 1960s. Among men ages 26 to 30, 28 percent of those born between 1946 and 1950 had a four-college degree, compared with 20 percent of those born five years earlier, 17 percent for those born 10 years earlier, and 24 percent for those born 10 years later (Figure 1). The Vietnam War draft, which men could avoid with an educational deferment, appears responsible for the surge in college attendance for men in the 1946 to 1950 birth cohort, who were 20 years old in the late 1960s (Card and Lemieux, 2001). For men born between 1951 and 1980, the share with a four-year college degree fluctuated between 24 percent and 28 percent. However, the share edged up to 29 percent for the early Millennials, born between 1981 and 1985, and surged to 34 percent for those born between 1986 and 1990, who were in their early 20s during and immediately after the Great Recession and likely pursued higher education because employment prospects were bleak (Mordechay, 2017). It remains to be seen whether the recent educational surge for men will persist now that the job market has improved.

Educational attainment for women has improved steadily over the past 50 years (Figure 2). The share of women ages 26 to 30 with a four-year college degree increased from 11 percent for those born between 1936 and 1940 to 20 percent for those born between 1946 and 1950 — the early Baby Boomers — to 33 percent for those born between 1976 and 1980 - the late Gen-Xers. This trend continued, and even accelerated, among Millennials, with 40 percent of women born between 1986 and 1990 having completed college by ages 26 to 30. Since the 1961 to 1965 birth cohort, women have been more likely than men to hold a four-year college degree. Millennials' high level of educational attainment bodes well for their future earnings and retirement security.

\section{Labor Force Participation}

Millennial men were less likely to participate in the labor force in their 20s and early 30s than previous cohorts (Figure 3). At ages 26 to 30, 88 percent of men born between 1986 and 1990 participated in the labor force, compared with 90 percent in the 1976 to 1980 birth cohort, 
93 percent in the 1961 to 1965 cohort, and 96 percent in the 1941 to 1945 cohort. Participation rates at ages 21 to 25 were especially low for Millennial men born between 1986 and 1990, with only 77 percent participating in the labor force. The low participation rates for Millennials may simply reflect the high unemployment rates that existed early in their careers and discouraged them from looking for work, or they may have been related to their high college attendance rates (which may have also resulted from the poor job market). In fact, there is already some indication that Millennial men's participation rates may be catching up to those of earlier recent cohorts; at ages 31 to 35, men born between 1981 and 1985 were just about as likely to participate in the labor force as those born five years earlier. However, men born in the late 1970s were less likely to participate in the labor force than earlier cohorts, so the fact that Millennial men are catching up to them may not be particularly encouraging.

A more worrisome trend for future retirement security is the long-term decline in labor supply among men in their 40s and 50s. At ages 41 to 45, for example, male labor force participation rates fell from 93 percent for the 1941 to 1945 birth cohort to 90 percent for the 1971 to 1975 birth cohort. This decline has been concentrated among men with no more than a high school education, perhaps because technological change and increased globalization reduced employers' demand for low-skilled and middle-skilled workers (Aaronson et al., 2014; Beaudry, Green, and Sand, 2016; Council of Economic Advisers, 2016; Juhn et al., 1991; Juhn and Potter, 2006). Rising receipt of Social Security Disability Insurance benefits and the growing opioid epidemic may also play a role in the growth of male labor force dropouts (Autor et al., 2016; Autor and Duggan, 2003; Bound and Burkhauser, 1999; French and Song, 2014; Krueger, 2017).

An encouraging sign for retirement security is the recent increase in labor force participation among older men. Men born between 1951 and 1955 were 11 percentage points more likely to participate in the labor force at ages 61 to 65 than those born 20 years earlier. This recent surge reflects higher educational levels among older adults, changes in Social Security rules that increased work incentives, and erosion in DB pension and retiree health insurance coverage from private-sector employers (Friedberg and Webb, 2005; Gustman and Steinmeier, 2015; Johnson, Davidoff, and Perese, 2003; Mermin, Johnson, and Murphy, 2007; Song and Manchester, 2007). 
Working longer can significantly improve the lives of older adults. Extending the work life and delaying retirement benefit take-up can bolster financial security at older ages (Maestas and Zissimopoulos, 2010), because adults who work longer can receive higher monthly Social Security benefits, accumulate more employer-sponsored pensions, save part of their additional earnings, and shrink the period over which their retirement savings are spread. Butrica, Smith, and Steuerle (2006) show that average annual retirement incomes rise 9 percent when older adults work an additional year and 56 percent when they work an additional five years. Working longer might also improve health and happiness at older ages by keeping people physically and mentally active, allowing them to maintain social networks, and giving purpose to their lives (Calvo, 2006). However, employment gains after age 65 have been concentrated among college graduates (Johnson and Wang, 2017).

Millennial women's labor force participation rates have not, to date, fallen as far behind the participation rates of previous cohorts as they have for their male counterparts (Figure 4). At ages 26 to 30, female participation rates were 74 percent for the 1981 to 1985 cohort and 75 percent for the 1986 to 1990 cohort, compared with 76 percent for the 1976 to 1980 cohort. Although the Great Recession appears to have reduced Millennial women’s labor force participation rates, the downward pressure created by the weak economy was somewhat offset by the long-term generational increase in women's labor supply. Among women ages 31 to 35, for example, those in the 1981 to 1985 cohort were more likely to participate in the labor force than women born before 1956. As other studies have noted, however, generational gains in women's labor force participation have slowed over the past two decades (Blau and Kahn, 2007). Across generations, female labor supply tends to dip when women move through their 30s, as they work less when raising children, but there is no evidence that women have become more likely over the past two decades to leave the labor force to raise children (Goldin and Mitchell, 2017). Women, like men, are also lengthening their careers, working more at older ages than earlier generations (Goldin and Katz, 2016).

\section{Full-Time Employment}

The percentage of young men working full time has fallen sharply over the past decade (Figure 5). At ages 26 to 30, 80 percent of men in the 1986 to 1990 birth cohort were employed full time, down 6 percentage points relative to those born 10 years earlier and down 8 percentage 
points relative to those born 25 years earlier. Full-time employment has also been slowly declining at middle age, following the pattern we observed for labor force participation. At ages 46 to 50, men born between 1971 and 1975 were 7 percentage points less likely to work full time than men born between 1946 and 1950. However, full-time employment rates at older ages (after age 60) increased over the past two decades.

Full-time employment rates for women in their early 30s increased steadily for 30 years, from those born in the first half of the 1930s through those born in the first half of the 1960s (Figure 6). Since then, full-time employment rates have generally stabilized at about 60 percent (although rates dipped for most ages in 2011, when unemployment rates were high). So far, fulltime employment rates for Millennial women is similar to full-time employment rates for recent earlier cohorts and higher than the rates for cohorts born before 1955. As with older men, fulltime employment for older women has increased over the past 20 years.

\section{Earnings}

Although Millennial men have generally earned less than men born 30 or more years earlier, their earnings so far have been roughly comparable to those in recent cohorts (Figure 7). Among men ages 25 to 29 employed full-time, median annual earnings were \$38,500 (in inflation-adjusted 2015 dollars) for the 1986 to 1990 birth cohort, about 5 percent higher than the median for the 1976 to 1980 cohort and the 1966 to 1970 cohort and 7 percent lower than the median for the 1971 to 1975 cohort. However, median inflation-adjusted annual earnings at ages 25 to 29 were 29 percent higher for full-time male workers born between 1941 and 1945 than those born between 1986 and 1990 .

The recent stagnation in median earnings reflects deteriorating labor market prospects for low- and middle-skilled men. Technological advancements, increasing globalization, and declining union membership have increased earnings for men in the top of the quarter of the earnings distribution, as earnings in the bottom half of the distribution fell or remained flat (Gottschalk and Danziger, 2005; Holzer and Hlavac, 2012; Kopczuk, Saez, and Song, 2007; Mishel, 2015; Rose, 2016). Rising health care costs have also increased the share of compensation going to fringe benefits, suppressing growth in cash earnings (Burtless and Milusheva, 2012). 
Millennial women, by contrast, are generally earning more than previous cohorts of women employed full time (Figure 8). Median inflation-adjusted annual earnings for full-time workers ages 25 to 29 was higher for the 1986 to 1990 cohort than for any other cohort going back to 1936. Similarly, median inflation-adjusted annual earnings for full-time workers ages 30 to 34 was higher for the 1981 to 1985 cohort than any other cohort we observed except for the 1976 to 1980 cohort, which was only \$100 higher. The evidence indicates that the long-term growth in women's earnings has continued through the Millennial generation, although it has slowed substantially.

\section{Employer-Sponsored Retirement Plan Coverage}

The share of full-time workers in the CPS/ASEC reporting employer-sponsored retirement plan coverage fell sharply across all age groups in 2016 relative to previous years. Between 2011 and 2016, retirement plan coverage rates for the 1976 to 1980 cohort declined 5 percentage points for men employed full time (Appendix Table 7) and 8 percentage points for women employed full time (Appendix Table 8). However, these declines seem to indicate a problem with the recent CPS/ASEC retirement plan data. The survey questionnaire related to pensions was redesigned in 2014, and comparisons of coverage rates using the old survey instrument and the new survey instrument show that rates were much lower after the redesign (Copeland, 2016). Moreover, coverage rates reported by the BLS's National Compensation Survey did not decline after 2014.

Because of the apparent problems with the survey redesign, we restricted the sample to data from 1981 to 2011 and reran the tabulations. Participation rates in employer-sponsored retirement plans among full-time male employees generally fell with each successive cohort (Figure 9). For the 1951 to 1955 cohort, coverage rates peaked at ages 45 to 49 at 62 percent. Among those born 10 years later, only 53 percent had coverage at that age. The decline in unionization and the growth in service industries, where retirement plan coverage is less common than in goods-producing industries, appear at least partly responsible for falling coverage rates (Costo, 2006; Wiatrowski, 2004). However, coverage rates seem to be dropping more slowly for people born between 1976 and 1990 than for previous cohorts. At ages 25 to 29, full-time male employees born between 1981 and 1985 have about the same coverage rate as those born between 1976 and 1980 . 
Retirement plan coverage has also dipped for women working full-time, but the declines have not been nearly as dramatic (Figure 10). For older cohorts, coverage among full-time employees did not differ much by sex. At ages 45 to 49, female coverage rates peaked at 60 percent for the 1951 to 1955 cohort and fell to 54 percent for those born 10 years later. For more recent cohorts, women working full-time had higher retirement plan coverage rates than their male counterparts. At ages 25 to 29, women in the 1976 to 1980 cohort and the 1981 to 1985 cohort who worked full time were about as likely to participate in an employer-sponsored retirement plan as their late Boomer counterparts born between 1961 and 1965.

\section{Marriage}

Marriage is an important source of retirement security, because it allows spouses to pool resources and insure against risks and qualifies retirees for spouse and survivor benefits from Social Security (and from employer pensions if they have them). However, the institution of marriage has been eroding for decades for both men and women (Cherlin, 2010). For men, each successive cohort has increasingly postponed marriage, and marriage rates for earlier cohorts have plateaued in middle age at successively lower levels (Figure 11). At ages 51 to 55, 66 percent of men in the 1961 to 1965 cohort were married, compared with 77 percent of men born 20 years earlier. An encouraging sign is that marriage rates are no longer falling for men in their late 30s. At ages 36 to 40, men in the 1976 to 1980 birth cohort are just about as likely to be married as those born 5 or 10 years earlier. Marriage rates for men born between 1976 and 1990 have been increasing rapidly as they move through their 20s and early 30s, suggesting that men are still delaying marriage but that the likelihood that they will ever marry is no longer dropping.

Marriage patterns are similar for women, who have increasingly delayed marriage over the past four decades, perhaps to pursue education or a career (Figure 12). At ages 26 to 30, for example, 81 percent of women born between 1941 and 1945 were married, compared with only 42 percent of women born between 1986 and 1990. As with men, however, the share of women who were married in middle age no longer appears to be declining. Women in the 1976 to 1980 birth cohort were just as likely to be married at ages 36 to 40 as those in the 1971 to 1975 birth cohort. 


\section{Homeownership}

Homeownership is an important financial resource in retirement. Retirees can avoid rental payments by owning a home, and homeowners may tap into their housing wealth to supplement their retirement income. The overall homeownership rate-the number of owneroccupied housing units divided by the total number of occupied housing units-increased from World War II through 2005, when it hit a high of 69 percent, and then fell to 64 percent in 2017 following the financial crisis, Great Recession, and collapse of the housing bubble (Garriga, Gavin, and Schlagenhuaf, 2006; U.S. Census Bureau, 2017). Much of the rise in homeownership through 2005 resulted from economic growth that made homeownership more affordable and from financial market innovations and regulatory changes that increased access to mortgage finance (Garriga, Gavin, and Schlagenhuaf, 2006; Li, 2005). The aging of the large Baby Boom generation, which moved into their 30s and 40s in the 1980s and 1990s, also appears to have raised the homeownership rate, because homeownership generally becomes more common with age, up to typical retirement ages.

However, our calculations of CPS/ASEC data that hold age constant show that homeownership has been declining across the age span for several decades (Figure 13). Unlike the Census Bureau's homeownership rate, which shows the share of households in an owneroccupied dwelling, our calculations show the share of adults who own a home. At ages 61 to 65, the share of adults owning a home fell from 80 percent for the 1941 to 1945 birth cohort to 74 percent for the 1951 to 1955 cohort. At ages 51 to 55, the likelihood of owning a home fell from 80 percent for the 1931 to 1935 birth cohort to 67 percent for the 1961 to 1965 cohort. And at ages 41 to 45, the likelihood of homeownership fell from 75 percent for the 1931 to 1935 birth cohort to 59 percent for the 1971 to 1975 cohort. Homeownership has stabilized at younger ages for people born between 1961 and 1980. However, it slipped again for Millennials. At ages 26 to 30, only 28 percent of those born between 1981 and 1985 and 24 percent of those between 1986 and 1990 owned a home, compared with 35 percent of those born between 1976 and 1980 and 47 percent of those born between 1951 and 1955. This long-term decline in homeownership predated the Great Recession and related financial crisis. 


\section{Household Net Worth}

Figure 14 reports median per capita household net worth, in constant 2015 dollars, by sixyear age and birth cohort groups. The SCF data used to compute these estimates cover 1989 to 2013. The most noteworthy feature of the chart is the decline in net worth following the 2007 collapse in housing values, the 2008 stock market crash, and the Great Recession, as can be seen by the drop at the end of each line in the figure. Between 2007 and 2013, median net worth fell between 16 and 28 percent for each cohort between the ages of 38 to 43 and 68 to 73 in 2007 .

Younger people, who did not have much to lose, and older people, who were less likely to have been heavily invested in equities or to have been laid off, lost less. Median household net worth remained virtually unchanged between 2007 and 2013 for people born between 1970 and 1975, who were ages 32 to 37 in 2007, and grew 32 percent for people born between 1976 and 1981, who were ages 26 to 31. Nonetheless, the economic downturn clearly harmed these younger people, who otherwise would have experienced strong growth in household wealth. Median household net worth increased 122 percent over the next six years for the 1964 to 1969 cohort at ages 32 to 37 and roughly doubled over the next six years for the 1970 to 1975 cohort and the 1964 to 1969 cohorts at ages 26 to 31 .

Disregarding 2013 data because of the anomalies created by the financial crisis, we see that household wealth increased rapidly through about one's early 60s and that each successive cohort born in the 1930s, 1940s, 1950s, and early 1960s generally had more net worth than the preceding cohort. At ages 56 to 61, for example, median household net worth was 168 percent higher for the 1946 to 1951 birth cohort than the 1928 to 1933 birth cohort, born 18 years earlier. However, growth in household net worth has been slowing. Median net worth at ages 38 to 43 was only 17 percent higher for those in the 1964 to 1969 birth cohort than those born 18 years earlier, and at ages 32 to 37 median net worth was lower for those in the 1970 to 1975 cohort than those born 18 years earlier.

The financial crisis and Great Recession wiped out these gains. Between October 2007 and February 2009, the S\&P 500 index lost 53 percent of its value. Five years after the 2008 stock market crash, each cohort born after 1945 had lower median net worth than the preceding cohort had at the same age, even though the S\&P 500 index exceeded its October 2007 value by March 2013 (and has continued to grow). Unless younger generations can recover, these losses could threaten future retirement security. 


\section{Financial Wealth}

Across all cohorts, the likelihood of having financial wealth increased with age, and nearly all adults — about 95 percent—held some financial assets by the time they reached their 40s (Figure 15). The share of adults with some financial wealth increased with each successive cohort up to those born between 1952 and 1957, and then leveled off, although those born between 1964 and 1981 were more likely to hold financial assets at ages 26 to 31 than the late Boomers born between 1958 and 1963.

Median inflation-adjusted financial wealth for adults with holdings generally increased through 2007 with each succeeding cohort until the 1958 to 1963 cohort (Figure 16). At ages 50 to 55, for example, median financial wealth was about twice as high for those in the 1952 to 1957 cohort as for those in the 1934 to 1939 cohort. Later cohorts have fallen behind their predecessors. Median financial wealth at ages 38 to 43 was lower for the 1964 to 1969 cohort than for those born six years earlier, and median financial wealth at ages 32 to 37 was lower for the 1970 to 1975 cohort than for the previous six-year cohort. These two cohort comparisons related wealth levels in 2007 and 2001. Outcomes for later cohorts appeared more ominous when we incorporated into the analysis 2013 data, which included the effects of the financial crisis and Great Recession. Median 2013 financial wealth for each cohort born after 1945 was lower than for the previous cohort at the same age, often by a substantial amount. Median financial wealth was 72 percent lower in 2013 than 2007 at ages 50 to 55, for example, and 47 percent lower at ages 26 to 31 .

The outlook for the most recent generation appeared somewhat more promising when we considered only retirement account holdings. The share of adults holding a retirement account generally increased with each successive birth cohort, peaking at 70 percent in the 1952 to 1957 birth cohort, although retirement account ownership has declined recently (Figure 17). The most recent birth cohorts were somewhat less likely to hold a retirement account after age 31 than those in the 1958 to 1963 cohort. Moreover, the share with an account fell between 2007 and 2013 for people ages 44 and older. An encouraging sign, however, is that median account balances have been increasing steadily over time, and the median balance for members of the 1976 to 1981 cohort with accounts was higher that the median balance for their counterparts in earlier cohorts at the same age (Figure 18). Median account balances were higher in 2013 than 2007. These results are generally consistent with data from IRA administrators and retirement 
plan recordkeeping organizations, which show that median IRA balances increased 31 percent from 2010 to 2014 (Copeland, 2017), while median 401(k) balances fell by about one-third between 2007 and 2008 before rebounding in 2013 to about their 2007 levels (VanDerhei et al., 2017).

\section{Housing Wealth}

Homeownership was more common in our SCF sample than in our CPS/ASEC sample, because we restricted our SCF sample to household heads and their spouses, excluding adults who had not established their own households (whom we included as non-homeowners in our CPS/ASEC sample). Our SCF homeownership rates did not vary much by cohort, although they generally fell between 2007 and 2013 for people younger than traditional retirement age (Figure 19). Nearly 8 in 10 household heads and their spouses ages 44 to 49 were homeowners in 2007. Six years later, only 3 in 4 those ages 50 to 55 were homeowners.

Among homeowners younger than 62 in 2001, median housing wealth surged between 2001 and 2007 and then plunged between 2007 and 2013, the endpoint of each line in Figure 20. For all homeowner cohorts, however, median inflation-adjusted housing wealth was higher in 2013 than 2001. For the 1952 to 1957 birth cohort, median housing wealth among homeowners increased 79 percent from 2001 to 2007 and fell 24 percent between 2007 and 2013. Through 2007, housing wealth increased rapidly with each successive cohort. At ages 44 to 49, median wealth was 64 percent higher for the 1958 to 1963 birth cohort than the cohort born six years earlier, partly because the mid-2000s housing bubble boosted home values for the later cohort. Even before the housing bubble, however, the 1958 to 1963 cohort had substantially more housing wealth than the previous cohort. After the collapse in housing prices after 2007, median housing wealth for cohorts after 1945 fell below the inflation-adjusted median for the cohort born six years earlier but remained above the median for the cohort born 12 years earlier. Most

of these gains, however, were concentrated among homeowners living in and around major cities on the East and West Coasts.

\section{Household Debt}

The growth in household debt is one of the most striking changes in household finances over the past quarter-century. The share of household heads and spouses with debt has not 
changed much at midlife or younger ages, although it has fallen somewhat over the past two decades for people their 20s, 30s, and early 40s (Figure 21). Debt has increased much more at

older ages. At ages 62 to 67, 76 percent of those in the 1940 to 1945 cohort held debt, compared with 64 percent of those in the 1928 to 1933 cohort.

Median debt holdings among people with debt has risen sharply over time. At ages 50 to 55, median debt for debtholders was \$62,200 in the 1952 to 1957 cohort, compared with only $\$ 18,700$ for debtholders in the 1940 to 1945 cohort, 12 years earlier (Figure 22). Median debt peaked at ages 38 to 43 at $\$ 77,500$ for adults in the 1964 to 1969 birth cohort, nearly twice as high as the median at that age for adults in the 1952 to 1957 cohort. Increases in housing prices, financial innovations that increased access to credit, demographic shifts, and low and stagnating incomes spurred the rise in household indebtedness (Barba and Pivetti, 2009; Dynan and Kohn, 2007). Student loan debt has also been growing (Brown et al., 2014). Both the likelihood of holding debt and the median debt level for debtholders declined sharply between 2007 and 2013. However, debt levels have been rising since 2013 and reached an all-time high in the second quarter of 2017 (Federal Reserve Bank of New York, 2017). As people enter retirement with more debt, debt service payments could strain their financial resources (Butrica and Karamcheva, 2013; Karamcheva, 2013).

\section{Retirement Income Projections}

Turning to future retirement income, we estimated that median per capita family income at age 70 will generally increase over time. For both men and women, DYNASIM4 projected that median traditional income at age 70 - the cash income measure used by the Census Bureau-will be higher for the 1946 to 1955 cohort than the previous 10-year cohort, which turned age 70 between 2006 and 2015 (Table 1). Median age-70 incomes were projected to fall for the 1956 to 1965 birth cohort — the late baby boomers — but then rise steadily over time. The projected increases depended on assumptions about future wage growth. When we followed the Social Security trustees’ optimistic annual wage growth assumption of 1.2 percent—our high wage-growth assumption-we projected that median per capita age-70 income for men and women combined will reach \$38,000 in 2015 inflation-adjusted dollars for the late Gen-Xers and early Millennials, born between 1976 and 1985. This projection is 15 percent higher than the projection for those born 40 years earlier (between 1936 and 1945). When we assumed more 
moderate wage growth of 0.81 percent per year, DYNASIM4 projected that median per capita age-70 income would be \$36,000 for the late Gen-Xers and early Millennials, 9 percent more than for those born 40 years earlier. Projected median per capita age-70 income for the late GenXers and early Millennials fell to \$35,000, 6 percent more than for those born 40 years earlier, when we assumed relatively slow wage growth of 0.70 percent per year.

Patterns were similar when we compared age-70 incomes across cohorts using the total potential income measure. This measure included the annuitized value of 80 percent of household financial assets and better reflects the impact on financial security of the shift from DB pensions to DC retirement accounts. Overall median age-70 income was 8 percent higher using the total potential income measure than the traditional cash measure under the moderatewage-growth assumption and 13 percent higher under the high-wage-growth assumption. Compared with the 1936 to 1945 cohort, median total potential income was 16 percent for the 1976 to 1985 cohort under the high-wage-growth assumption, 5 percent higher under the moderate-wage-growth assumption, and 3 percent higher under the low-wage-growth assumption. However, under the low- and moderate-wage-growth assumptions, median age-70 incomes for the 1946 to 1955 cohorts exceeded those for the 1976 to 1985 cohorts.

If real average wages grow 1.2 percent per year, we projected that median inflationadjusted annuitized income at age 70 will be 8 percent higher for the 1976 to 1985 birth cohort than for the 1946 to 1955 cohort. If real average wages instead grow at 0.82 percent per year, median inflation-adjusted annuitized income at age 70 will be 3 percent higher for the 1976 to 1985 birth cohort than for the 1946 to 1955 cohort.

Projected median per capita family income at age 70 grew faster for women than men, especially for the traditional cash income measure, reflecting the growth in women's earnings. Compared with the 1936 to 1945 cohort, projected median traditional cash income in the 1976 to 1985 cohort under the moderate-wage-growth assumption was 13 percent higher for women but only 3 percent higher for men. However, for each cohort median age-70 income was higher for men than women for both income measures under all wage-growth assumptions.

For lower- and middle-income retirees, much of the projected income increase came from higher Social Security incomes. For 70-year-olds in the middle income quintile, projected mean per capita income in the 1976 to 1985 birth cohort was \$2,400 higher than in the 1936 to 1945 cohort, after we adjusted for inflation (Table 2). Projected mean income grew \$5,700 for Social 
Security, $\$ 2,400$ for income from financial assets, and $\$ 1,000$ for earnings, while mean DB pension income fell $\$ 6,700$. For adults in the bottom income quintile, mean Social Security income grew $\$ 1,800$ over the period, while a $\$ 700$ average gain in income from financial assets was exactly offset by losses in average DB pension income and SSI. Earnings growth accounted for most of the projected age-70 income gains from the 1936 to 1945 cohort to the 1976 to 1985 cohort for adults in the top income quintile. Their mean DB pension income fell $\$ 20,800$.

Although we projected that median age-70 incomes will rise in the coming decades, we projected that the share of 70-year-olds able to replace at least 75 percent of the average annual earnings they received between ages 50 and 54-a common rule of thumb for retirement income adequacy—will decline (Table 3). According to DYNASIM4 projections that used the traditional income measure and moderate wage growth assumptions, the share of 70-year-olds with a replacement rate below 75 percent will increase from 38 percent for the 1936 to 1945 birth cohort to 44 percent for the 1966 to 1975 cohort and 46 percent for the 1976 to 1985 cohort. The share with potentially inadequate retirement incomes was somewhat lower when the projections used the high wage-growth assumption—44 percent for the 1976 to 1985 cohort-

and somewhat higher when they used the low wage-growth assumption—47 percent for the 1976 to 1985 cohort.

We projected that more older adults would be able to replace 75 percent of their preretirement earnings if they annuitized their financial assets, but the projected share likely to experience lower living standards in retirement than while working again increased over time. Using the total potential income measure, we estimated that 40 percent of adults in the 1976 to 1985 cohort would fall short of a 75 percent replacement rate at age 70 if wages grew moderately over time, up from 32 percent for the 1936 to 1945 cohort and 30 percent for the 1956 to 1965 cohort. The corresponding share for the 1976 to 1985 cohort was 38 percent under the high wage-growth assumption and 41 percent under the low wage-growth assumption.

\section{Conclusion}

How future generations fare in retirement will depend largely on how much they earned and saved when they were younger. Many recent employment, earnings, and savings trends are discouraging. Men's labor force participation rates prior to age 55 continue to decline, and their median wages have been stagnant for decades. Full-time male workers born in the late 1970s 
and early 1980s were less likely to participate in an employer-sponsored retirement plan than previous cohorts, and their female cohorts were less likely to participate than those born a decade earlier. Adults younger than traditional retirement ages have accumulated less wealth than previous cohorts. Other trends have been more encouraging, however. Gen-X and Millennial women worked and earned more in their 20s and 30s than now-retired women did at those ages. And Millennial men and women are much more likely to have a four-year college degree than previous cohorts.

Our projections showed that median, age-70 income will be higher for Gen-Xers and Millennials than previous generations, but they face a higher risk of seeing their living standards fall when they retire. Using a measure of retirement income that includes payouts that could be collected from an actuarially fair annuity valued at 80 percent of a retiree's financial assets and retirement accounts, we found that 40 percent of 70-year-olds born between 1976 and 1985 would be unable to replace at least 75 percent of the inflation-adjusted average annual earnings that they and their spouse received from ages 50 to 54, under the assumption that average wages grow at the same rate as they did between 1966 and 2015. By comparison, replacement rates at age 70 would likely fall short of the 75 percent threshold for 32 percent of those born between 1936 and 1945, and for 30 percent of those born between 1956 and 1965.

Retirement is still more than three decades away for most people born in the 1980s, and their financial security in old age will hinge on several factors that have yet to play out. The future course of stock market returns, interest rates, housing prices, and inflation will affect future retirement incomes. How long people tend to work, which will depend partly on how health trajectories evolve, will help determine financial security for future retirees. Policy choices regarding retirement programs, especially Social Security, will play a role. Our projections assumed that Social Security will pay all future retirees the benefits that they are scheduled to receive under current rules. However, because Social Security faces a long-term financing shortfall, the program's trustees project that within two decades it will be able to pay only about three-quarters of scheduled benefits (Board of Trustees, Federal Old-Age and Survivors Insurance and Federal Disability Insurance Trust Funds, 2017). If Congress cuts benefits to close the funding gap, or does nothing and allows benefits to fall by about onequarter, future retirement incomes will be much lower than we projected. 
How rapidly future wages grow will also shape future retirement security. Wage growth will depend on labor productivity, which will likely continue to rise, although perhaps more slowly than in the past (Fernald, 2016; Gordon, 2014). However, the relationship between wage growth and labor productivity growth has been weakening, reducing the share of the nation's output that goes to labor. Over the past decade, productivity in the non-farm business sector increased 12.3 percent, while real compensation of labor increased only 5.1 percent (Solow, 2015). Declining unionization, the shift from labor to capital, and rising employer health care costs may explain why wages have not been keeping pace with productivity growth (Congressional Budget Office, 2016; Ginsburg, 2014; Karabarbounis and Neiman 2013).

Rising out-of-pocket spending on health care and long-term services and supports (LTSS) poses an additional threat to future retirees' financial security. Although Medicare covers nearly all older adults, out-of-pocket spending on Medicare premiums, premiums for supplemental private insurance, copays, and uncovered services can be financially burdensome. Hatfield et al. (2016) project that between 2012 and 2030, the median share of income that adults ages 65 and older spend on medical services will increase from 10 to 14 percent. Fronstin and VanDerhei (2017) estimate that a 65-year-old man would need $\$ 127,000$ in savings to be 90 percent certain of covering all future medical expenses, and a 65-year-old woman would need \$143,000. Spending on LTSS, which includes nursing home care, residential care, and home care, can be even more burdensome for families because Medicare does not usually cover them, relatively few people have private long-term care insurance, and Medicaid pays only for people who have already depleted virtually all their wealth. Favreault and Dey (2015) project that people turning 65 today need to set aside $\$ 36,000$ by age 65 to cover expected lifetime out-of-pocket costs for intensive LTSS, and about 1 in 10 will need to set aside more than $\$ 100,000$.

Our analysis focused on median outcomes, describing the employment, earnings, and wealth of the "typical” worker and the income that the "typical” future retiree is likely to receive. However, medians mask important differences across population subgroups. Employment, earnings, and household wealth vary substantially by educational level, race and ethnicity, household structure, immigrant status, and other factors (Autor, 2014; Cobb-Clark and Hildebrand, 2006; Fisher and Houseworth, 2017; Hirsch and Winters, 2014; McKernan et al., 2014). Consequently, future retirement income for people with limited education, people of 
color, and people who spent much of their lives outside of marriage may differ significantly from the overall median outcome. Future research should explore these distributional differences. 


\section{References}

Aaronson, Stephanie, Tomaz Cajner, Bruce Fallick, Felix Galbis-Reig, Christopher Smith, and William Wascher. 2014. "Labor Force Participation: Recent Developments and Future Prospects.” Brookings Papers on Economic Activity (Fall 2014): 197-275.

Autor, David H. 2014. "Skills, Education, and the Rise of Earnings Inequality among the 'Other 99 Percent."” Science 34(6186): 843-851.

Autor, David H. and Mark H. Duggan. 2003. "The Rise in the Disability Rolls and the Decline in Unemployment.” Quarterly Journal of Economics 118(1): 157-206

Autor, David H., Mark Duggan, Kyle Greenberg, and David S. Lyle. 2016. “The Impact of Disability Benefits on Labor Supply: Evidence from the VA's Disability Compensation Program.” American Economic Journal: Applied Economics 8(3): 31-68.

Barba, Aldo and Massimo Pivetti. 2009. "Rising Household Debt: Its Causes and Macroeconomic Implications - A Long-Period Analysis.” Cambridge Journal of Economics 33(1): 113-137.

Beaudry, Paul, David A. Green, and Benjamin M. Sand. 2016. "The Great Reversal in the Demand for Skill and Cognitive Tasks.” Journal of Labor Economics 34(1): s199-s247.

Biggs, Andrew G. and Sylvester Schieber. 2014. “Is There a Retirement Crisis?” National Affairs 20(Summer).

Blau, Francine D. and Lawrence M. Kahn. 2007. "Changes in the Labor Supply Behavior of Married Women: 1980-2000.” Journal of Labor Economics 25(3): 393-438.

Board of Trustees, Federal Old-Age and Survivors Insurance and Federal Disability Insurance Trust Funds. 2016. The 2016 Annual Report of the Board of Trustees of the Federal Old-Age and Survivors Insurance and Federal Disability Insurance Trust Funds. Washington, DC. Available at: https://www.ssa.gov/oact/tr/2016/tr2016.pdf

- 2017. The 2017 Annual Report of the Board of Trustees of the Federal Old-Age and Survivors Insurance and Federal Disability Insurance Trust Funds. Washington, DC: U.S. Social Security Adminstration. Available at: https://www.ssa.gov/oact/tr/2017/tr2017.pdf

Bound, John and Richard V. Burkhauser. 1999. "Economic Analysis of Transfer Programs Targeted on People with Disabilities.” In Handbook of Labor Economics, Vol. 3, edited by Orley Ashenfelter and David Card, 3417-3528. Amsterdam: New Holland. 
Brown, Meta, Andrew Haughwout, Donghoon Lee, Joelle Scally, and Wilbert van der Klaauw. 2014. "Measuring Student Debt and Its Performance.” Staff Report No. 668. New York, NY: Federal Reserve Bank of New York. Available at: https://www.newyorkfed.org/medialibrary/media/research/staff_reports/sr668.pdf

Burtless, Gary and Sveta Milusheva. 2012. "Effects of Employer Health Costs on the Trend and Distribution of Social-Security-Taxable Wages.” Washington, DC: Brookings Institution. Available at: https://www.brookings.edu/wpcontent/uploads/2016/06/0509_health_wages_burtless.pdf

Butrica, Barbara A. and Nadia S. Karamcheva. 2013. "Does Household Debt Influence the Labor Supply and Benefit Claiming Decisions of Older Americans?” Working Paper 2013-22. Chestnut Hill, MA: Center for Retirement Research at Boston College. Available at: http://crr.bc.edu/wp-content/uploads/2013/12/wp_2013-221.pdf

Butrica, Barbara A. and Karen E. Smith. 2017 (forthcoming). "The Potential Impact of Mandated Employer Pension Programs on Retirement Savings.” Working Paper. Chestnut Hill, MA: Center for Retirement Research at Boston College.

Butrica, Barbara A., Karen E. Smith, and Howard M. Iams. 2012. "This Is Not Your Parents' Retirement: Comparing Retirement Income Across Generations.” Social Security Bulletin 72(1): 37-58.

Butrica, Barbara A., Karen E. Smith, and C. Eugene Steuerle. 2006. Working for a Good Retirement. Washington, DC: Urban Institute.

Butrica, Barbara A., Karen E. Smith, and Eric Toder. 2009. Retirement Security and the Stock Market Crash: What Are the Possible Outcomes? Washington, DC: Urban Institute.

— 2010. "What the 2008 Stock Market Crash Means for Retirement Security." Journal of Aging \& Social Policy 22(4): 339-359.

Calvo, Esteban. 2006. “Does Working Longer Make People Healthier and Happier?” Work Opportunity Issue in Brief 2. Chestnut Hill, MA: Center for Retirement Research at Boston College.

Card, David and Thomas Lemieux. 2001. "Going to College to Avoid the Draft: The Unintended Legacy of the Vietnam War." American Economic Review: Papers and Proceedings 91(2): 97-102.

Cherlin, Andrew J. 2010. "Demographic Trends in the United States: A Review of the Research in the 2000s." Journal of Marriage and Family 72(3): 403-419.

Cobb-Clark, Deborah A. and Vincent A. Hildebrand. 2006. "The Wealth and Asset Holding of US-Born and Foreign-Born Households: Evidence from SIPP Data." Review of Income and Wealth 52(1): 17-42. 
Congressional Budget Office. 2016. “The 2016 Long-Term Budget Outlook.” Washington, DC. Available at: https://www.cbo.gov/publication/51580

Copeland, Craig. 2011. "Target-Date Fund Use in 401(k) Plans and the Persistence of Their Use, 2007-2009.” Issue Brief No. 361. Washington, DC: Employee Benefits Research Institute. Available at: http://www.ebri.org/pdf/briefspdf/EBRI_IB_082011_No361_TDFs.pdf

— . 2016. "Another Year after the Current Population Survey Redesign and More Questions about the Survey's Retirement Plan Participation Estimates.” EBRI Notes 37(12): 1-14. Available at: https://www.ebri.org/pdf/notespdf/EBRI_Notes_11-no12-Nov16-CPS.pdf

. 2017. "Individual Retirement Account Balances, Contributions, Withdrawals, and Asset Allocation Longitudinal Results 2010-2014: The EBRI IRA Database.” Issue Brief 429. Washington, DC: Employee Benefit Research Institute. Available at: https://www.ebri.org/pdf/briefspdf/EBRI_IB_429_IRA-Long.17Jan17.pdf

Costo, Stephanie L. 2006. “Trends in Retirement Plan Coverage over the Last Decade.” Monthly Labor Review 129(2): 58-64.

Council of Economic Advisers. 2016. The Long-Term Decline in Prime-Age Male Labor Force Participation. Washington, DC: Executive Office of the President of the United States.

Czajka, John L., Jonathan E. Jacobson, and Scott Cody. 2003. "Survey Estimates of Wealth: A Comparative Analysis and Review of the Survey of Income and Program Participation.” Washington, DC: Mathematica Policy Research, Inc. Available at: https://www.ssa.gov/policy/docs/contractreports/SurveyEstimatesWealth.pdf

Davis, Steven J. and Till von Wachter. 2011. "Recessions and the Costs of Job Loss.” Brookings Papers on Economic Activity 2011(2): 1-72.

Dynan, Karen E. and Donald L. Kohn. 2007. "The Rise in U.S. Household Indebtedness: Causes and Consequence.” In The Structure and Resilience of the Financial System, edited by Christopher Kent and Jeremy Lawson, 84-113. Sydney: Reserve Bank of Australia.

Farber, Henry S. 2015. "Job Loss in the Great Recession and Its Aftermath: U.S. Evidence from the Displaced Workers Survey.” Working Paper 21216. Cambridge, MA: National Bureau of Economic Research.

Favreault, Melissa M. and Judith G. Dey. 2015. "Long-Term Services and Supports for Older Americans: Risks and Financing.” ASPE Issue Brief. Washington, DC: U.S. Department of Health and Human Services, Office of the Assistant Secretary for Planning and Evaluation. Available at: https://aspe.hhs.gov/system/files/pdf/106211/ElderLTCrbrev.pdf 
Favreault, Melissa M., Karen E. Smith, and Richard W. Johnson. 2015. “The Dynamic Simulation of Income Model (DYNASIM): An Overview.” Washington, DC: Urban Institute. Available at: http://www.urban.org/research/publication/dynamic-simulationincome-model-dynasim-overview

Federal Reserve Bank of New York. 2017. Quarterly Report on Household Debt and Credit. 2017:Q2. New York, NY: Federal Reserve Bank of New York. Available at: https://www.newyorkfed.org/medialibrary/interactives/householdcredit/data/pdf/HHDC 2017Q2.pdf

Fernald, John G. 2016. “Reassessing Longer-Run U.S. Growth: How Low?” Working Paper Series 2016-18. San Francisco, CA: Federal Reserve Bank of San Francisco. Available at: https://ideas.repec.org/p/fip/fedfwp/2016-18.html

Fisher, Jonathan D. and Christina A. Houseworth. 2017. “The Widening Black-White Wage Gap among Women.” Labour 31(3): 288-308.

French, Eric and Jae Song. 2014. "The Effect of Disability Insurance Receipt on Labor Supply.” American Economic Journal: Economic Policy 6(2): 291-337.

Friedberg, Leora and Anthony Webb. 2005. "Retirement and the Evolution of Pension Structure.” Journal of Human Resources 40(2): 281-308.

Fronstin, Paul and Jack VanDerhei. 2017. "Savings Medicare Beneficiaries Need for Health Expenses: Some Couples Could Need as Much as \$350,000.” EBRI Notes 38(1): 1-12. Available at: https://www.ebri.org/pdf/notespdf/EBRI_Notes_Hlth-Svgs.v38no1_31Jan17.pdf

Furlong, Frederick T. 2016. "Household Formation Among Young Adults.” FRBSF Economic Letter 2016(17): 1-5.

Garriga, Carlos, William T. Gavin, and Don Schlagenhauf. 2006. "Recent Trends in Homeownership.” Federal Reserve Bank of St. Louis Review 88(5): 397-411.

Ginsburg, Paul B. 2014. "Alternative Health Spending Scenarios: Implications for Employers and Working Households.” Health Policy Issue Brief. Washington, DC: The Brookings Institution. Available at: https://www.brookings.edu/research/health-policy-issue-briefhealth-spending-implications-for-employers-and-working-households/

Goldin, Claudia and Lawrence F. Katz. 2016. "Women Working Longer: Facts and Some Explanations.” Working Paper 22607. Cambridge, MA: National Bureau of Economic Research.

Goldin, Claudia and Joshua Mitchell. 2017. "The New Life Cycle of Women’s Employment: Disappearing Humps, Sagging Middles, Expanding Tops.” Journal of Economic Perspectives 31(1): 161-182. 
Gordon, Robert J. 2014. “The Demise of U.S. Economic Growth: Restatement, Rebuttal, and Reflections.” Working Paper 19895. Cambridge, MA: National Bureau of Economic Research. Available at: https://ideas.repec.org/p/nbr/nberwo/19895.html

Gottschalk, Peter and Sheldon Danziger. 2005. "Inequality of Wage Rates, Earnings, and Family Income in the United States, 1975-2002.” Review of Income and Wealth 51(2): 231-254.

Grusky, David B., Bruce Western, and Christopher Wimer, eds. 2011. The Great Recession. New York, NY: Russell Sage Foundation.

Gustman, Alan and Thomas Steinmeier. 2015. "Effects of Social Security Policies on Benefit Claiming, Retirement and Saving.” Journal of Public Economics 129: 51-62.

Hatfield, Laura, Melissa M. Favreault, Thomas G. McGuire, and Michael E. Chernew. 2016. "Modeling Health Care Spending Growth of Older Adults." Health Services Research Published on-line December 26. doi 10.1111/1457-6773.12640.

Hirsch, Barry T. and John V. Winters. 2014. "An Anatomy of Racial and Ethnic Trends in Male Earnings in the U.S.” Review of Income and Wealth 60(4): 930-947.

Holzer, Harry J. and Marek Hlavac. 2012. “A Very Uneven Road: U.S. Labor Markets in the Past 30 Years.” New York, NY: Russell Sage Foundation. Available at: https://s4.ad.brown.edu/Projects/Diversity/Data/Report/report03082012.pdf.

Ibbotson Associates. 2014. Ibbotson SBBI 2014 Classic Yearbook: Market Results for Stocks, Bonds, Bills, and Inflation 1926-2014. Chicago, IL.

Johnson, Richard W., Amy J. Davidoff, and Kevin Perese. 2003. "Health Insurance Costs and Early Retirement Decisions.” Industrial and Labor Relations Review 56(4): 716-729.

Johnson, Richard W. and Claire Xiaozhi Wang. 2017. Educational Differences in Employment at Older Ages. Washington, DC: Urban Institute. Available at: http://www.urban.org/research/publication/educational-differences-employment-olderages.

Juhn, Chinhui, Kevin M. Murphy, Robert H. Topel, Janet L. Yellen, and Martin Neil Baily. 1991. "Why Has the Natural Rate of Unemployment Increased over Time?” Brookings Papers on Economic Activity 22(2): 75-142.

Juhn, Chinhui and Simon Potter. 2006. “Changes in Labor Force Participation in the United States.” Journal of Economic Perspectives 20(3): 27-46.

Karamcheva, Nadia. 2013. “Is Household Debt Growing for Older Americans?” Washington, DC: Urban Institute. Available at: http://www.urban.org/research/publication/householddebt-growing-older-americans 
Karabarbounis, Loukas and Brent Neiman. 2013. "The Global Decline of the Labor Share.” Working Paper 19136. Cambridge, MA: National Bureau of Economic Research. Available at: http://www.nber.org/papers/w19136

Kopczuk, Wojciech, Emmanuel Saez, and Jae Song. 2007. "Uncovering the American Dream: Inequality and Mobility in Social Security Earnings Data since 1937.” Working Paper 13345. Cambridge, MA: National Bureau of Economic Research.

Krueger, Alan B. 2017. "Where Have All the Workers Gone? An Inquiry into the Decline of the U.S. Labor Force Participation Rate.” Brookings Papers on Economic Activity conference draft, September 7-8. Available at: https://www.brookings.edu/wpcontent/uploads/2017/09/1_krueger.pdf

La Cava, Gianni. 2016. "Housing Prices, Mortgage Interest Rates, and the Rising Share of Capital in the United States.” Working Paper No. 572. Basel, Switzerland: Bank for International Settlements.

Lee, Kwan Ok and Gary Painter. 2013. "What Happens to Household Formation in a Recession?” Journal of Urban Economics 76: 93-109.

Li, Wenli. 2005. “Moving Up: Trends in Homeownership and Mortgage Indebtedness.” Business Review. Philadelphia, PA: Federal Reserve Bank of Philadelphia. Available at: https://philadelphiafed.org/-/media/research-and-data/publications/businessreview/2005/q1/brq105wl.pdf

Lockwood, Lee M. 2012. "Bequest Motives and the Annuity Puzzle.” Review of Economic Dynamics 15(2): 226-243.

Maestas, Nicole and Julie Zissimopoulos. 2010. “How Longer Work Lives Ease the Crunch of Population Aging.” Journal of Economic Perspectives 24(1): 139-60.

McKernan, Signe-Mary, Caroline Ratcliffe, Eugene Steuerle, and Sisi Zhang. 2014. "Impact of the Great Recession and Beyond: Disparities in Wealth Building by Generation and Race.” Working Paper. Washington DC: Urban Institute.

Mermin, Gordon B.T., Richard W. Johnson, and Dan Murphy. 2007. "Why Do Boomers Plan to Work Longer?” Journal of Gerontology: Social Sciences 62B (5): S286-S294.

Mishel, Lawrence. 2015. “Causes of Wage Stagnation.” Washington, DC: Economic Policy Institute. Available at: http://www.epi.org/publication/causes-of-wage-stagnation/

Mordechay, Kfir. 2017. “The Effects of the Great Recession on Educational Attainment: Evidence from a Large Urban High School District.” Urban Review 49(1): 47-71. 
Morningstar. 2012. “Target-Date Series Research Paper: 2012 Industry Survey.” Available at: http://corporate.morningstar.com/us/documents/MethodologyDocuments/MethodologyPa pers/TargetDateFundSurvey_2012.pdf

Morrissey, Monique. 2016. The State of American Retirement: How 401(k)s Have Failed Most American Workers. Washington, DC: Economic Policy Institute. Available at: http://www.epi.org/publication/retirement-in-america/

Munnell, Alicia H. 2014. “401(k)/IRA Holdings in 2013: An Update from the SCF.” Issue in Brief Number 14-15. Chestnut Hill, MA: Center for Retirement Research at Boston College. Available at: http://crr.bc.edu/wp-content/uploads/2014/09/IB_14-151.pdf

Munnell, Alicia H., Wenliang Hou, and Anthony Webb. 2014. "NRRI Update Shows Half Still Falling Short.” Issue in Brief 14-20. Chestnut Hill, MA: Center for Retirement Research at Boston College. Available at: http://crr.bc.edu/briefs/nrri-update-shows-half-stillfalling-short/

Oreopoulos, Philip, Till von Wachter, and Andrew Heisz. 2012. “The Short- and Long-Term Career Effects of Graduating in a Recession.” American Economic Journal: Applied Economics 4(1): 1-29.

Rhee, Nari. 2013. “The Retirement Savings Crisis: Is It Worse than We Think?” Washington, DC: National Institute on Retirement Security. Available at: http://www.nirsonline.org/storage/nirs/documents/Retirement\%20Savings\%20Crisis/retir ementsavingscrisis_final.pdf

Rose, Stephen. 2016. The Growing Size and Incomes of the Upper Middle Class. Washington, DC: Urban Institute. Available at: http://www.urban.org/sites/default/files/publication/81581/2000819-The-Growing-Sizeand-Incomes-of-the-Upper-Middle-Class.pdf

Ruggles, Steven, Katie Genadek, Ronald Goeken, Josiah Grover, and Matthew Sobek. 2015. Integrated Public Use Microdata Series: Version 6.0 [Machine-readable database]. Minneapolis: University of Minnesota, 2015.

Scholz, John Karl, Ananth Seshadri, and Surachai Khitatrakun. 2006. “Are Americans Saving ‘Optimally’ for Retirement?” Journal of Political Economy 114(4): 607-643.

Sevak, Purvi, David R. Weir, and Robert J. Willis. 2003/2004. "The Economic Consequences of a Husband's Death: Evidence from the HRS and AHEAD.” Social Security Bulletin 65(3): 31-44.

Short, Kathleen and Thesia Garner. 2012. “The Supplemental Poverty Measure: A Joint Project between the Census Bureau and the Bureau of Labor Statistics.” Washington DC: U.S. Census Bureau and Bureau of Labor Statistics. Available at: http://www.bls.gov/pir/spm/spm_pap_joint12.pdf 
Smeeding, Timothy. 2012. “Income, Wealth, and Debt and the Great Recession.” Stanford, CA: Stanford Center on Poverty and Inequality.

Smith, Karen E., Melissa M. Favreault, Barbara A. Butrica, and Philip Issa. 2010. Final Report: Modeling Income in the Near Term, Version 6. Project Report for the Social Security Administration. Washington, DC: Urban Institute.

Smith, Karen E., Melissa M. Favreault, and David Cashin. 2005. Modeling Income in the Near Term 4. Washington, DC: Urban Institute. Available at: http://www.urban.org/publications/411191.html

Smith, Karen E., Melissa M. Favreault, Caroline Ratcliffe, Barbara A. Butrica, Eric Toder, and Jon Bakija. 2007. Modeling Income in the Near Term 5. Project Report for the Social Security Administration. Washington, DC: Urban Institute.

Smith, Karen E., Mauricio Soto, and Rudolph G. Penner. 2009. "How Seniors Change Their Asset Holdings during Retirement.” Washington, DC: Urban Institute. Available at: http://www.urban.org/sites/default/files/publication/28266/412006-how-seniors-changetheir-asset-holdings-during-retirement.pdf

Solow, Robert. 2015. “The Future of Work: Why Wages Aren’t Keeping Up.” Pacific Standard, August 11. Available at: https://psmag.com/the-future-of-work-why-wages-aren-tkeeping-up-6fcfac468e4

Song, Jae G. and Joyce Manchester. 2007. "New Evidence on Earnings and Benefit Claims Following Changes in the Retirement Earnings Test in 2000.” Journal of Public Economics 91(3-4): 669-700.

Toder, Eric, Larry Thompson, Melissa M. Favreault, Richard W. Johnson, Kevin Perese, Caroline Ratcliffe, Karen E. Smith, Cori Uccello, Timothy Waidmann, Jillian Berk, Romina Woldemariam, Gary Burtless, Claudia Sahm, and Douglas Wolf. 2002. Modeling Income in the Near Term: Revised Projections of Retirement Income through 2020 for the 1931-1960 Birth Cohorts. Washington, DC: Urban Institute.

Toder, Eric, Cori Uccello, John O’Hare, Melissa M. Favreault, Caroline Ratcliffe, Karen E. Smith, Gary Burtless, and Barry P. Bosworth. 1999. Modeling Income in the Near Term: Projections of Retirement Income through 2020 for the 1931-1960 Birth Cohorts. Final Report. Washington, DC: Urban Institute.

Trovato, Frank and Nils B. Heyen. 2006. “A Varied Pattern of Change of the Sex Differential in Survival in the G7 Countries.” Journal of Biosocial Science 38(3): 391-401.

Urban Institute. 2015. “DYNASIM: Projecting Older Americans’ Future Well-Being.” Washington, DC. Available at: http://www.urban.org/research/publication/dynasimprojecting-older-americans-future-well-being 
— . 2016. "The State of Retirement: Grading America’s Public Pension Plans: Urban Institute's State and Local Employee Pension Plan Database.” Washington DC. Available at: http://apps.urban.org/features/SLEPP/data.html

U.S. Census Bureau. 2017. “Quarterly Residential Vacancies and Homeownership, Second Quarter 2017.” Washington, DC. Available at: https://www.census.gov/housing/hvs/files/currenthvspress.pdf

VanDerhei, Jack, Sarah Holden, Luis Alonso, and Steven Bass. 2017. “401(k) Plan Asset Allocation, Account Balances, and Loan Activity in 2015.” Issue Brief 436. Washington, DC: Employee Benefit Research Institute. Available at: https://www.ebri.org/pdf/briefspdf/EBRI_IB_436_K-update.3Aug17.pdf

Wiatrowski, William J. 2004. "Medical and Retirement Plan Coverage: Exploring the Decline in Recent Years.” Monthly Labor Review: 127(8): 29-36.

Wolff, Edward N. 2016. "Household Wealth Trends in the United States, 1962 to 2013: What Happened over the Great Recession?” Russell Sage Journal of the Social Sciences 2(6): 24-43. 
Figure 1. Percentage of Men Ages 26 to 30 with a Four-Year College Degree, by Birth Cohort

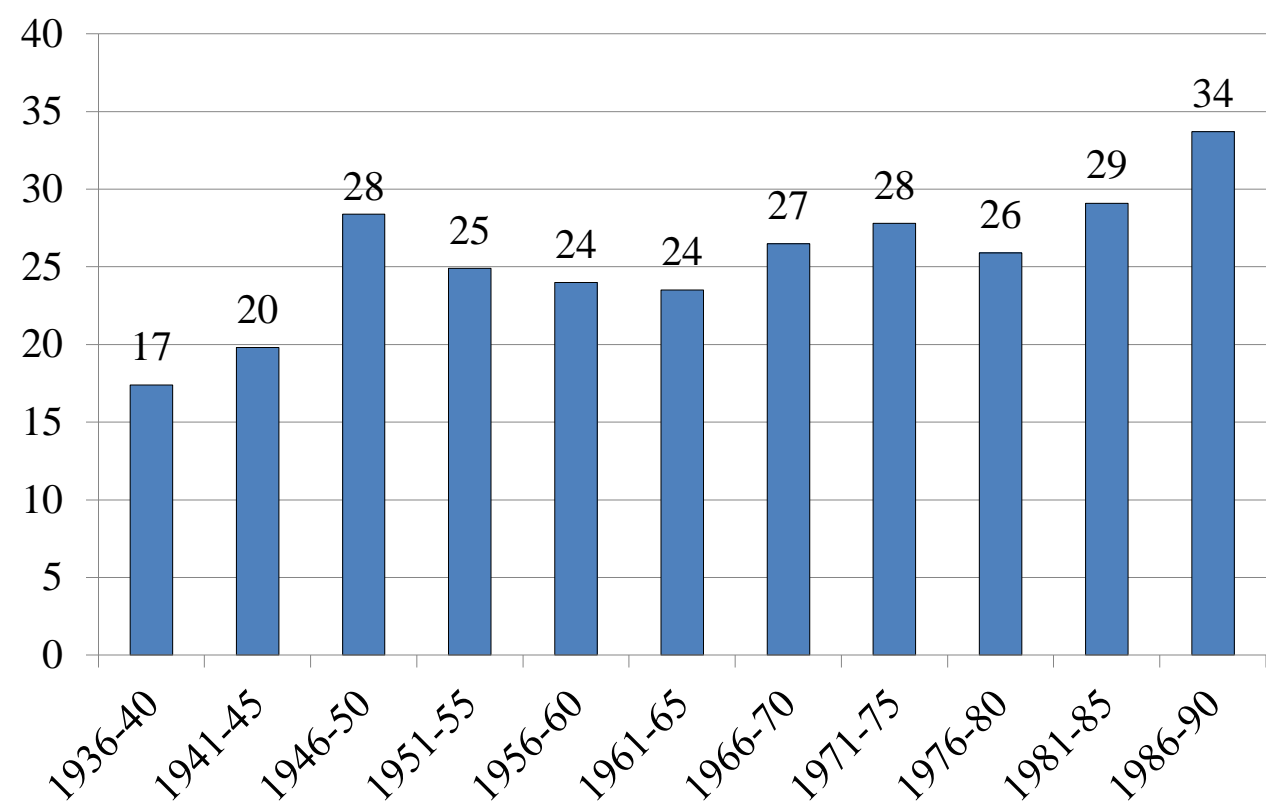

Birth cohort

Source: Authors' estimates from the Annual Social and Economic supplement to the Current Population Survey.

Figure 2. Percentage of Women Ages 26 to 30 with a Four-Year College Degree, by Birth Cohort

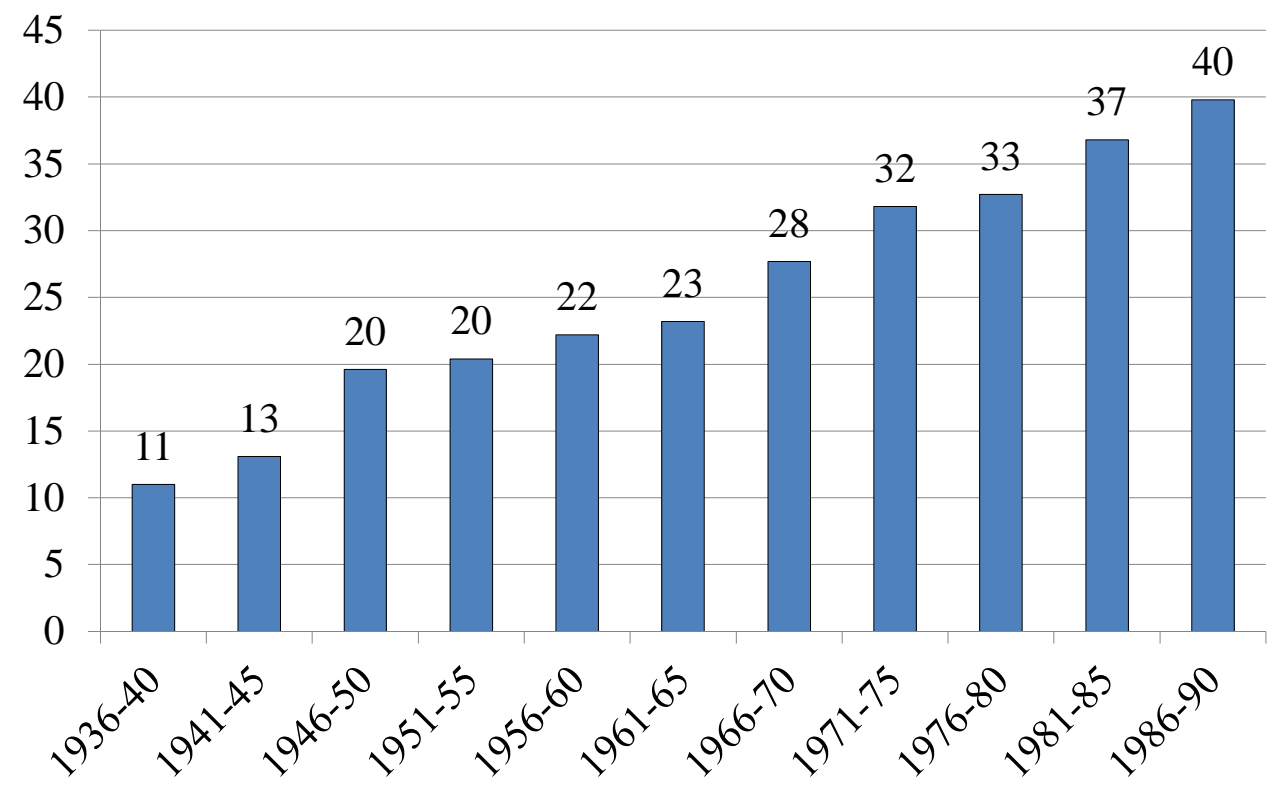

Birth cohort

Source: Authors' estimates from the Annual Social and Economic supplement to the Current Population Survey. 
Figure 3. Men's Labor Force Participation Rates, by Age and Birth Cohort (\%)

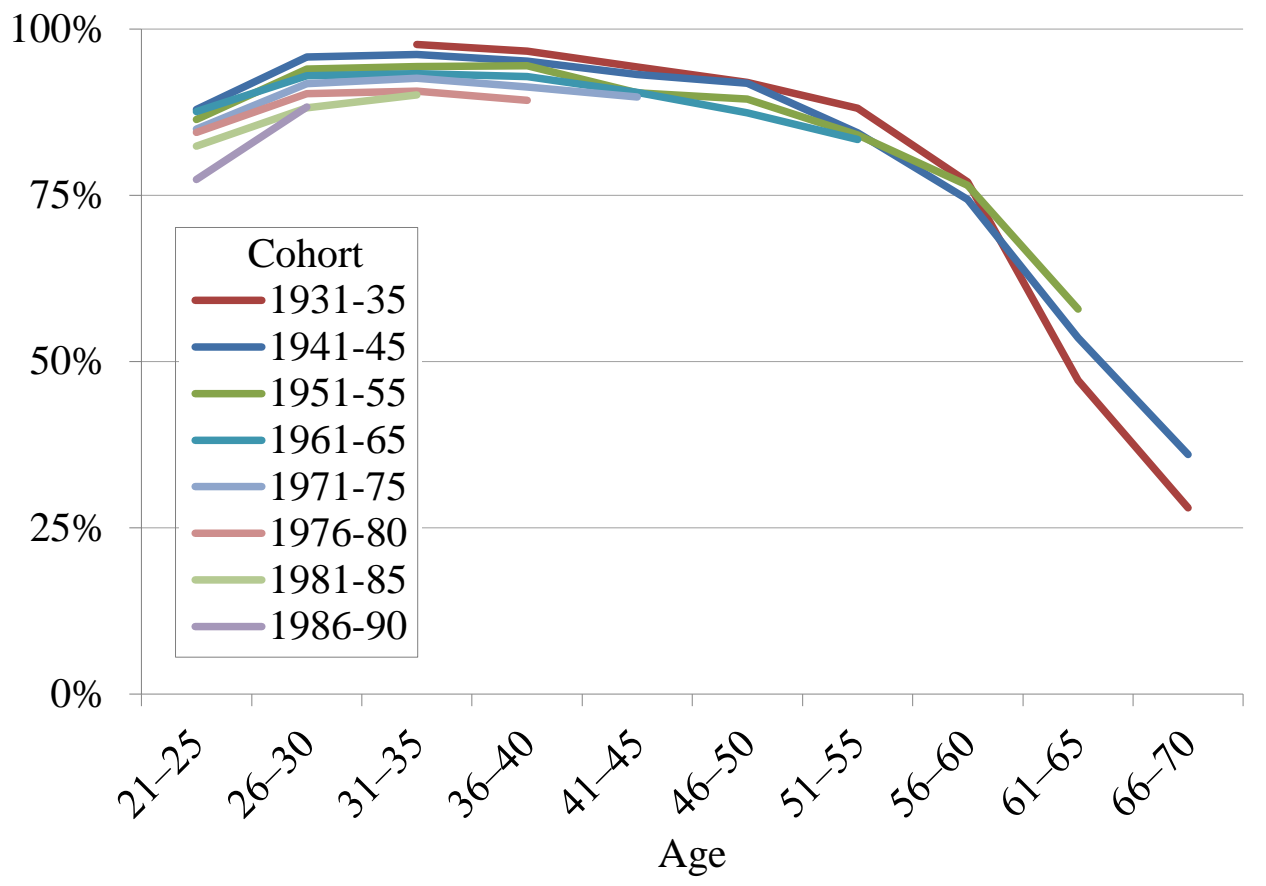

Note: The labor force participation rate is the share of the civilian noninstitutionalized population that is working or looking for work. Appendix Table 1 provides additional data.

Source: Authors' estimates from the Annual Social and Economic supplement to the Current Population Survey.

Figure 4. Women's Labor Force Participation Rates, by Age and Birth Cohort (\%)

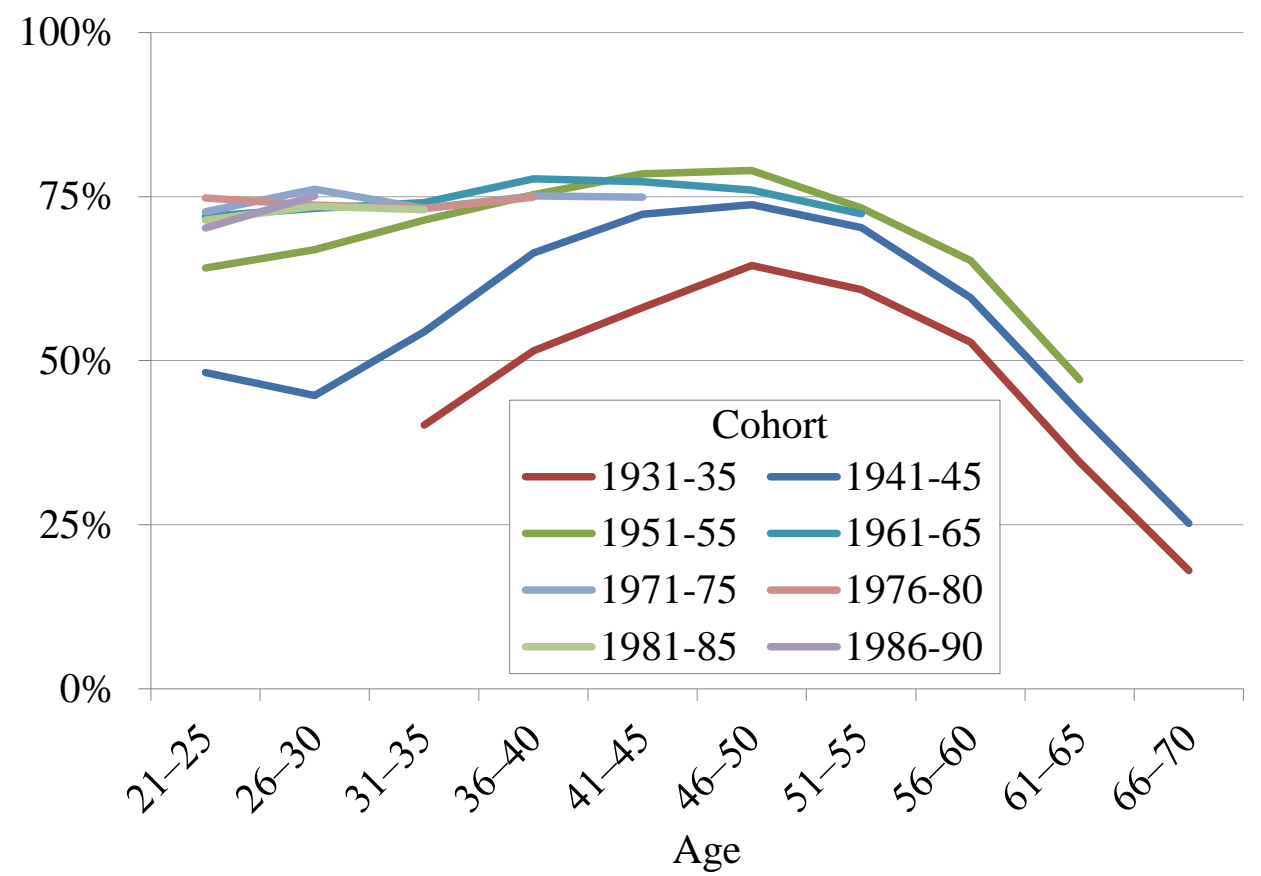

Note: The labor force participation rate is the share of the civilian noninstitutionalized population that is working or looking for work. Appendix Table 2 provides additional data.

Source: Authors' estimates from the Annual Social and Economic supplement to the Current Population Survey. 
Figure 5. Men's Full-Time Employment Rates, by Age and Birth Cohort (\%)

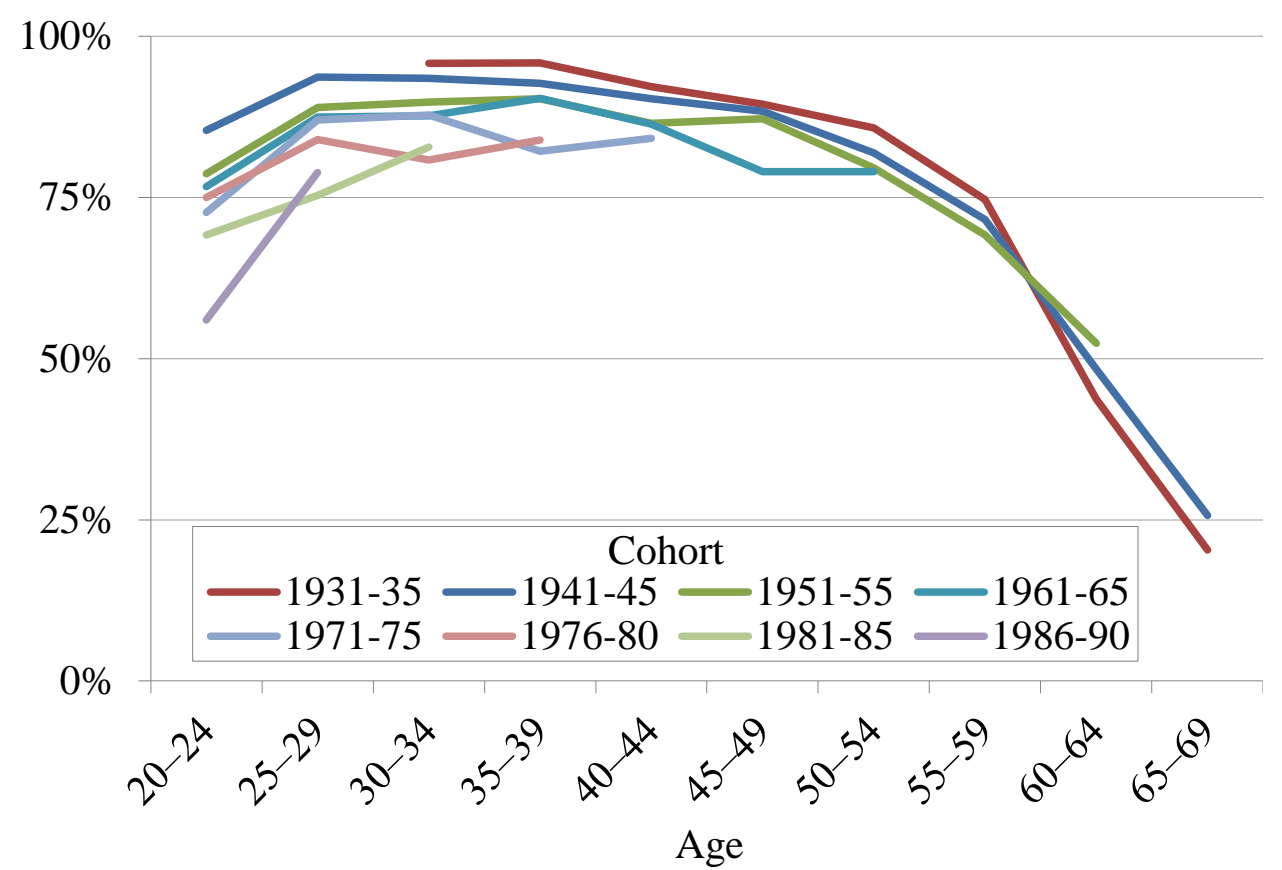

Note: The figure shows the percentage of civilian noninstitutionalized men employed full time. Appendix Table 3 provides additional data.

Source: Authors' estimates from the Annual Social and Economic supplement to the Current Population Survey.

Figure 6. Women's Full-Time Employment Rates, by Age and Birth Cohort (\%)

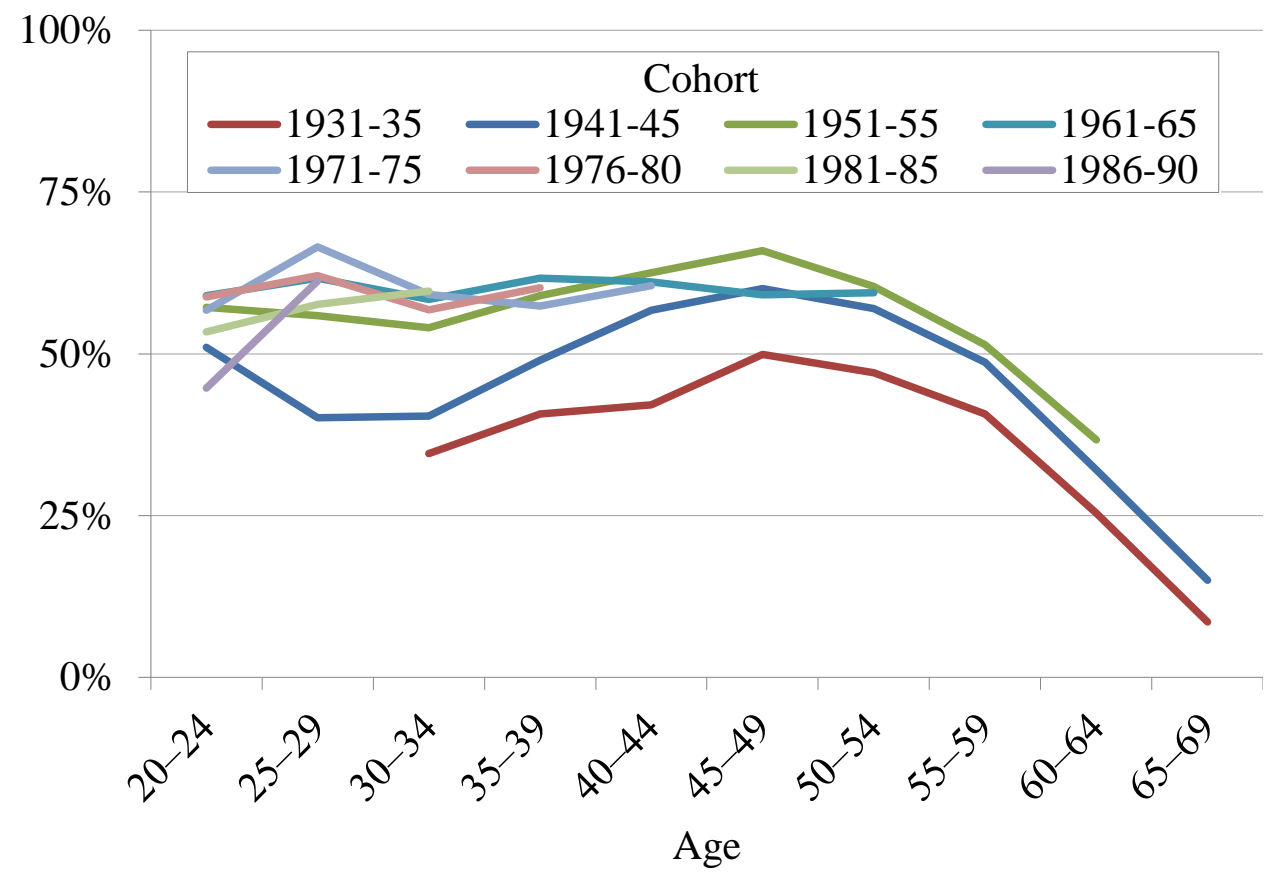

Note: The figure shows the percentage of civilian noninstitutionalized women employed full time. Appendix Table 4 provides additional data.

Source: Authors' estimates from the Annual Social and Economic supplement to the Current Population Survey. 
Figure 7. Men's Median Inflation-Adjusted Earnings, Full-Time Workers, by Age and Birth Cohort

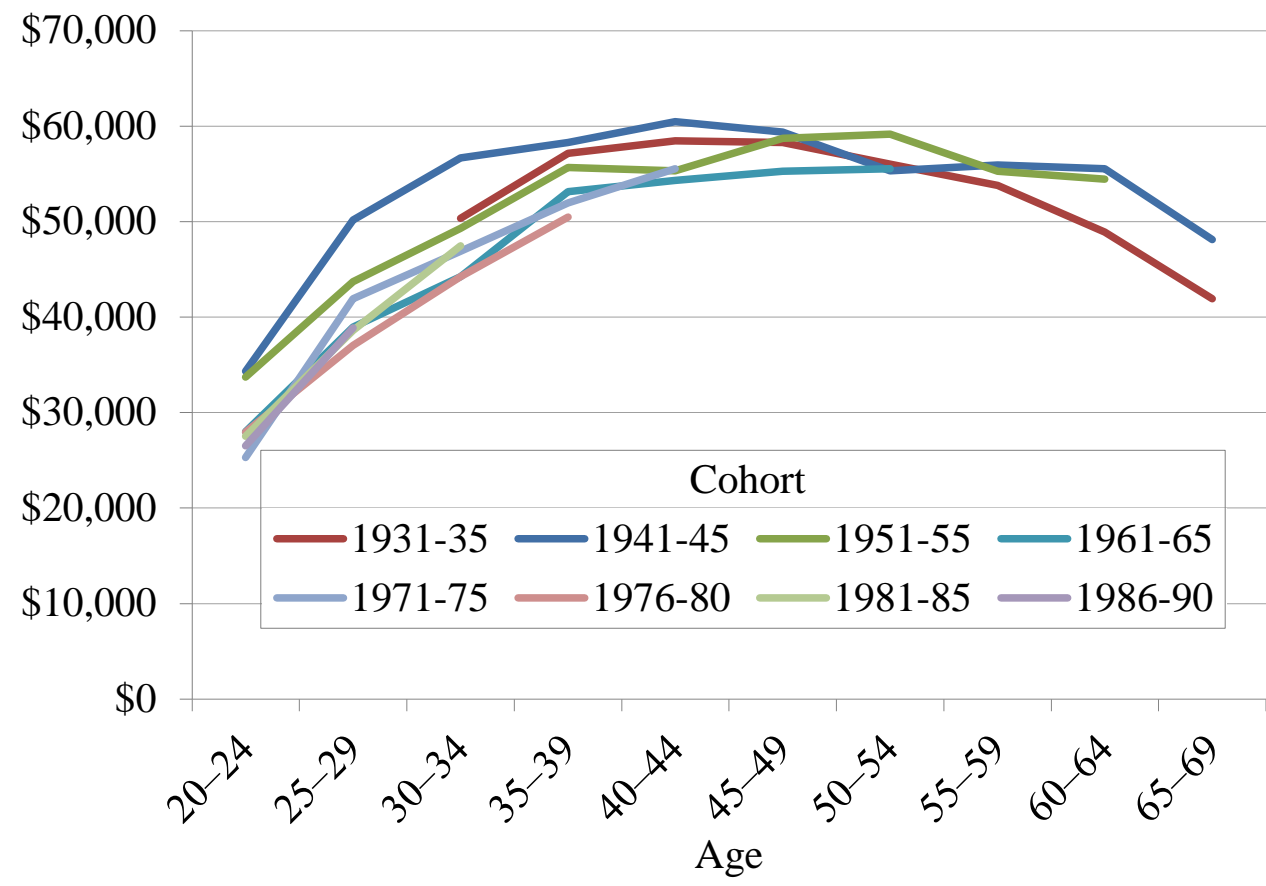

Note: Estimates are reported in constant 2015 dollars. Appendix Table 5 provides additional data.

Source: Authors' estimates from the Annual Social and Economic supplement to the Current Population Survey.

Figure 8. Women's Median Inflation-Adjusted Earnings, Full-Time Workers, by Age and Birth Cohort

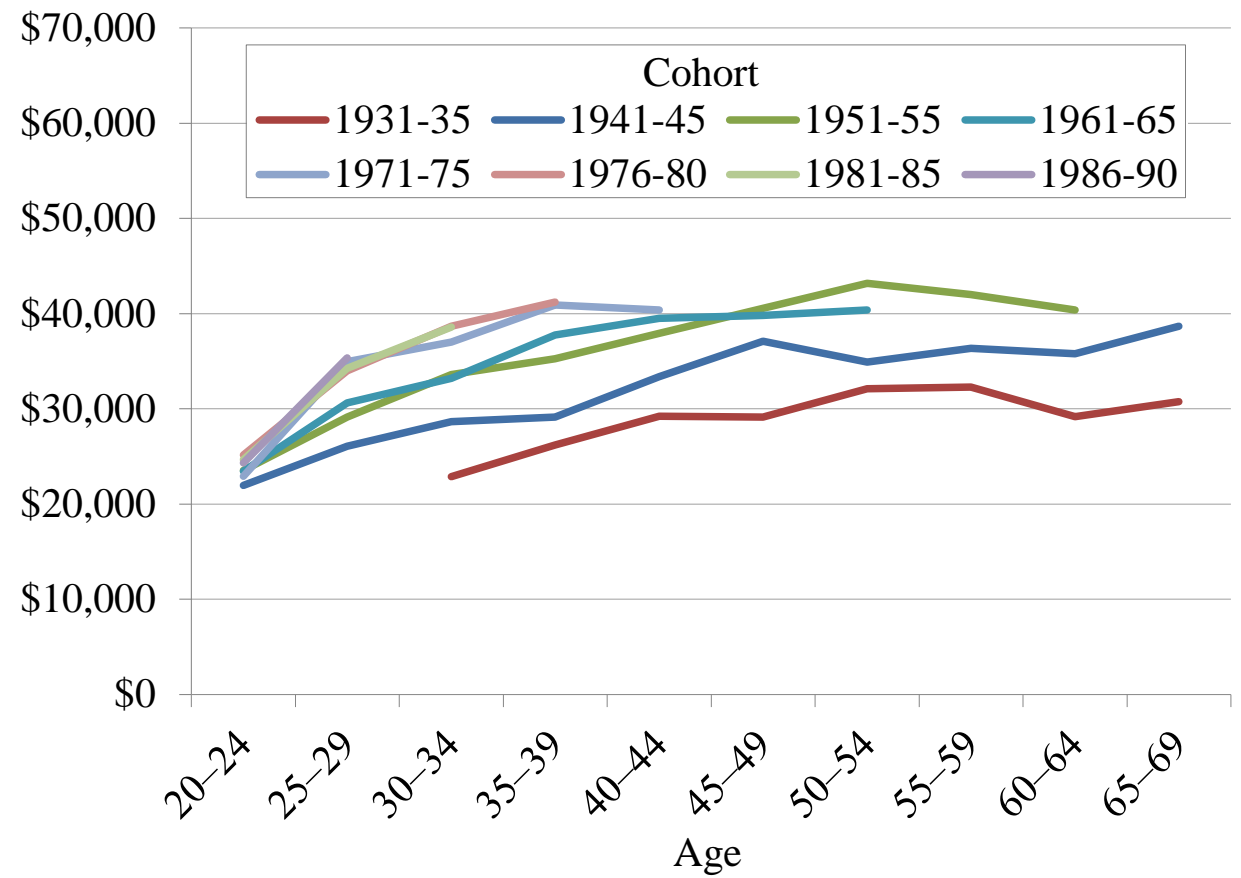

Note: Estimates are reported in constant 2015 dollars. Appendix Table 6 provides additional data.

Source: Authors' estimates from the Annual Social and Economic supplement to the Current Population Survey. 
Figure 9. Percentage of Full-Time Male Workers Participating in an Employer-Sponsored Retirement Plan, by Birth Cohort

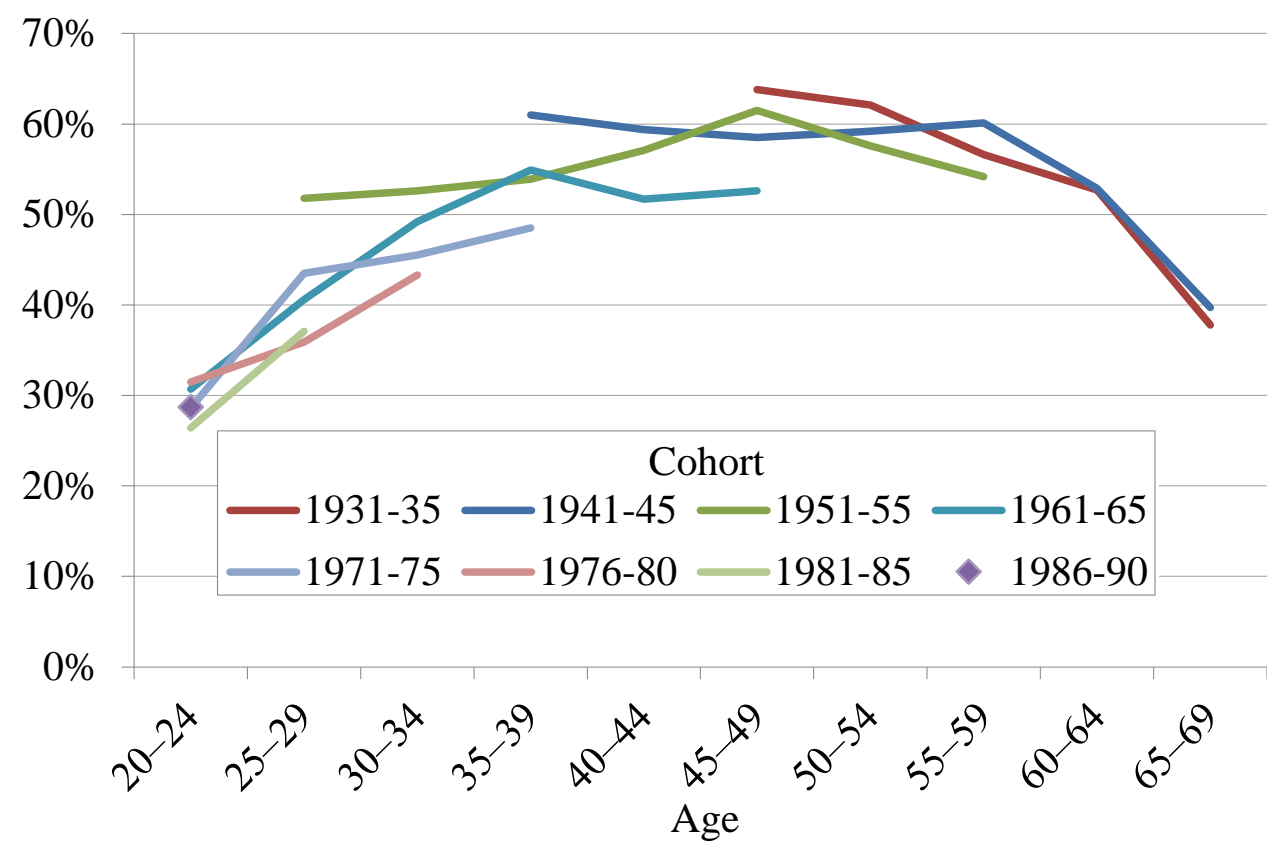

Note: The figure excludes 2016 data, because the CPS/ASEC appears to have underestimated retirement plan coverage since 2014. Appendix Table 7 provides additional data.

Source: Authors' estimates from the Annual Social and Economic supplement to the Current Population Survey.

Figure 10. Percentage of Full-Time Female Workers Participating in an Employer-Sponsored Retirement Plan, by Birth Cohort

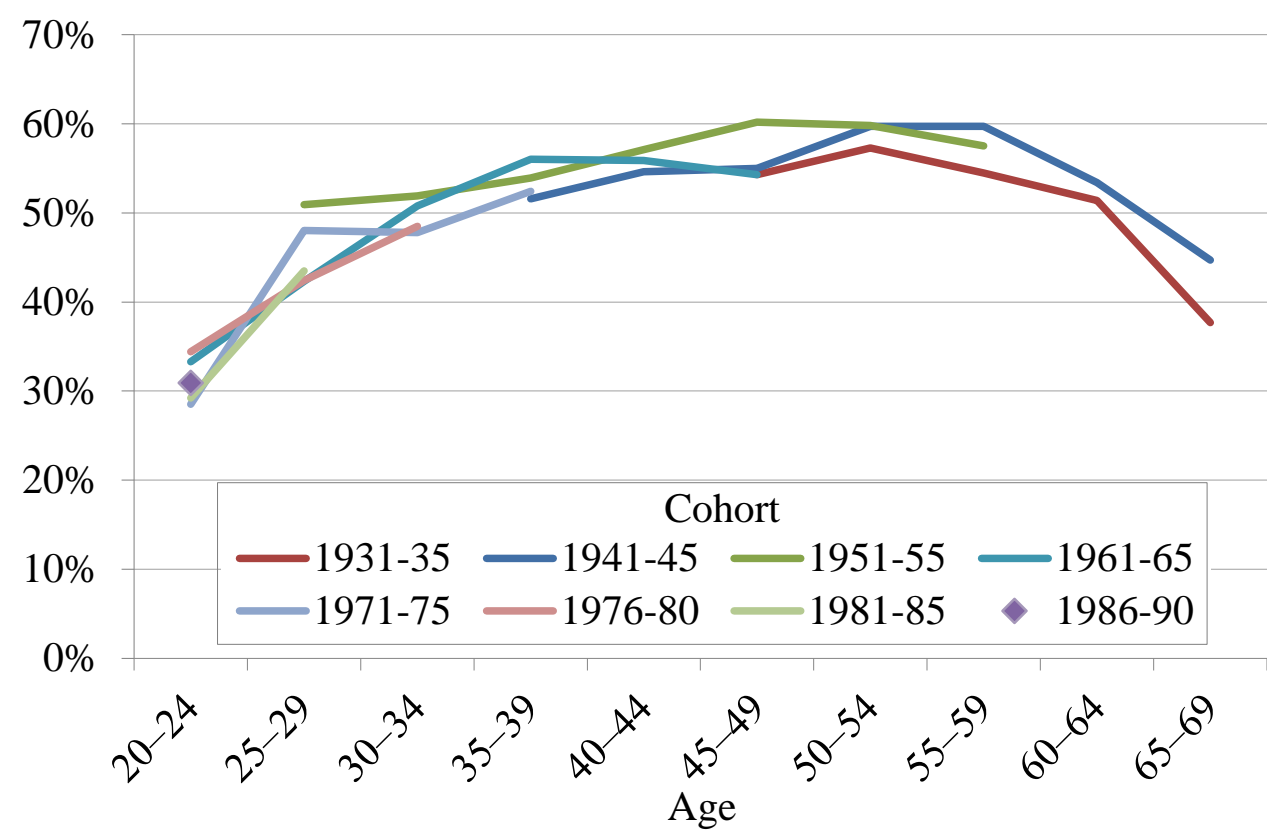

Note: The figure excludes 2016 data, because the CPS/ASEC appears to have underestimated retirement plan coverage since 2014. Appendix Table 8 provides additional data.

Source: Authors' estimates from the Annual Social and Economic supplement to the Current Population Survey. 
Figure 11. Percentage of Men Married, by Age and Birth Cohort

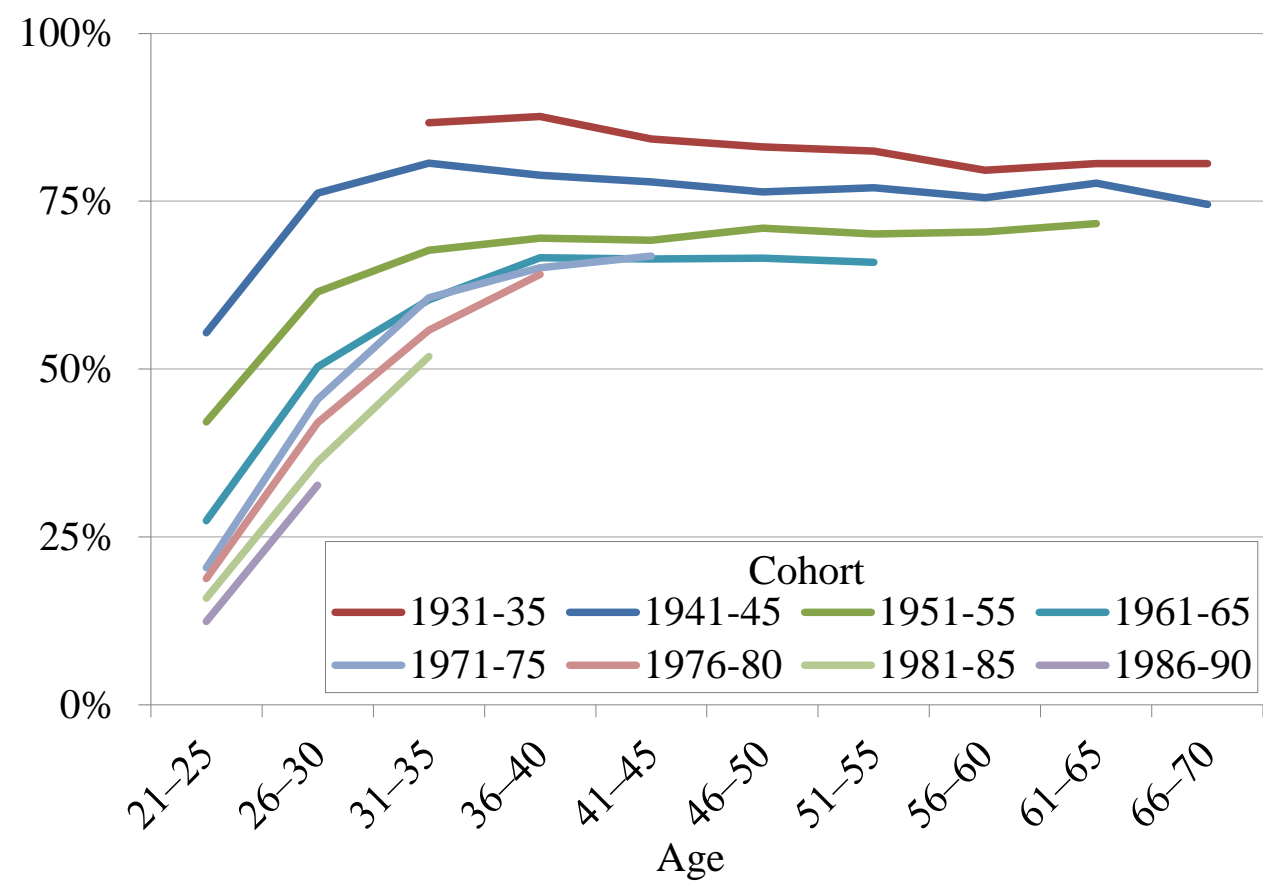

Note: Appendix Table 9 provides additional data.

Source: Authors' estimates from the Annual Social and Economic supplement to the Current Population Survey.

Figure 12. Percentage of Women Married, by Age and Birth Cohort

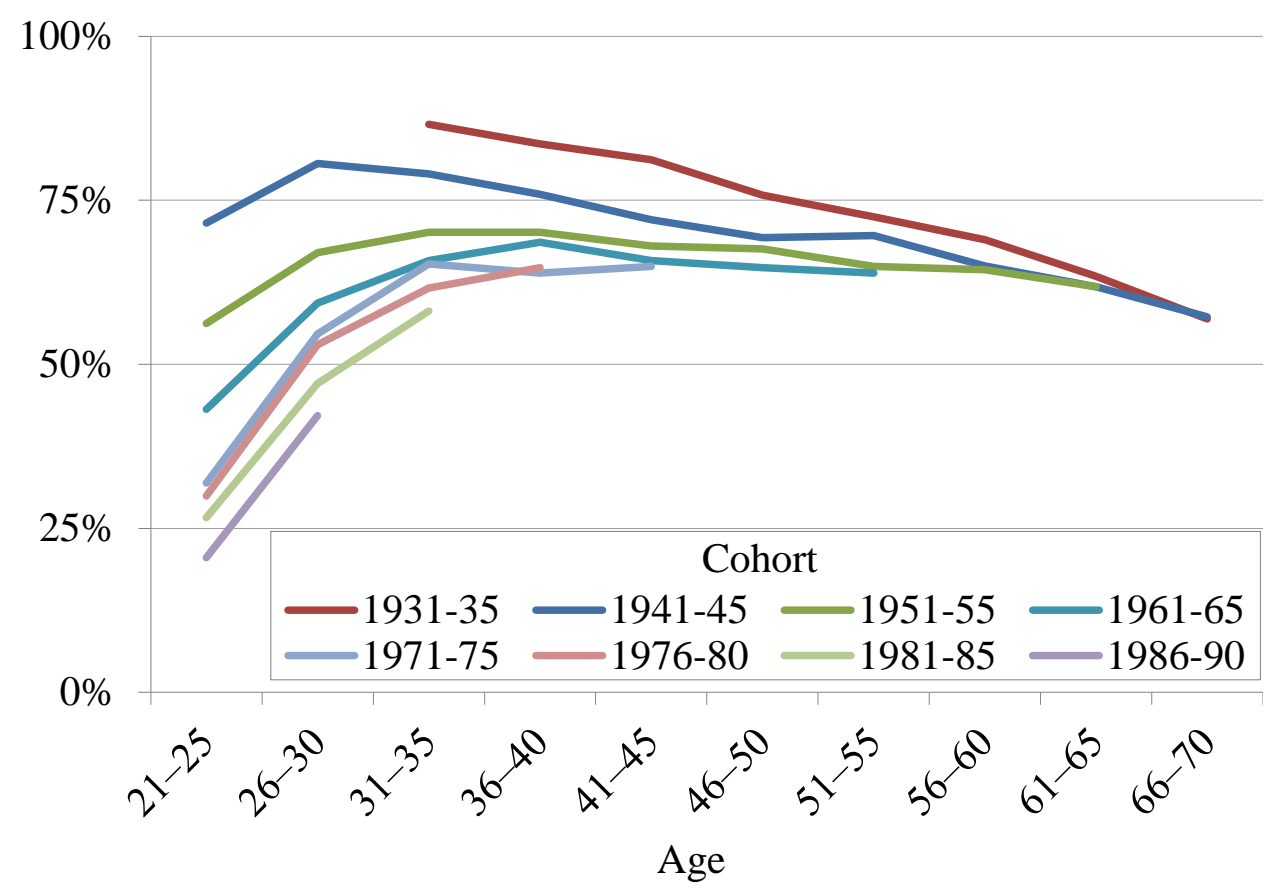

Note: Appendix Table 10 provides additional data.

Source: Authors' estimates from the Annual Social and Economic supplement to the Current Population Survey. 
Figure 13. Percentage of Adults Who Own a Home, by Age and Birth Cohort

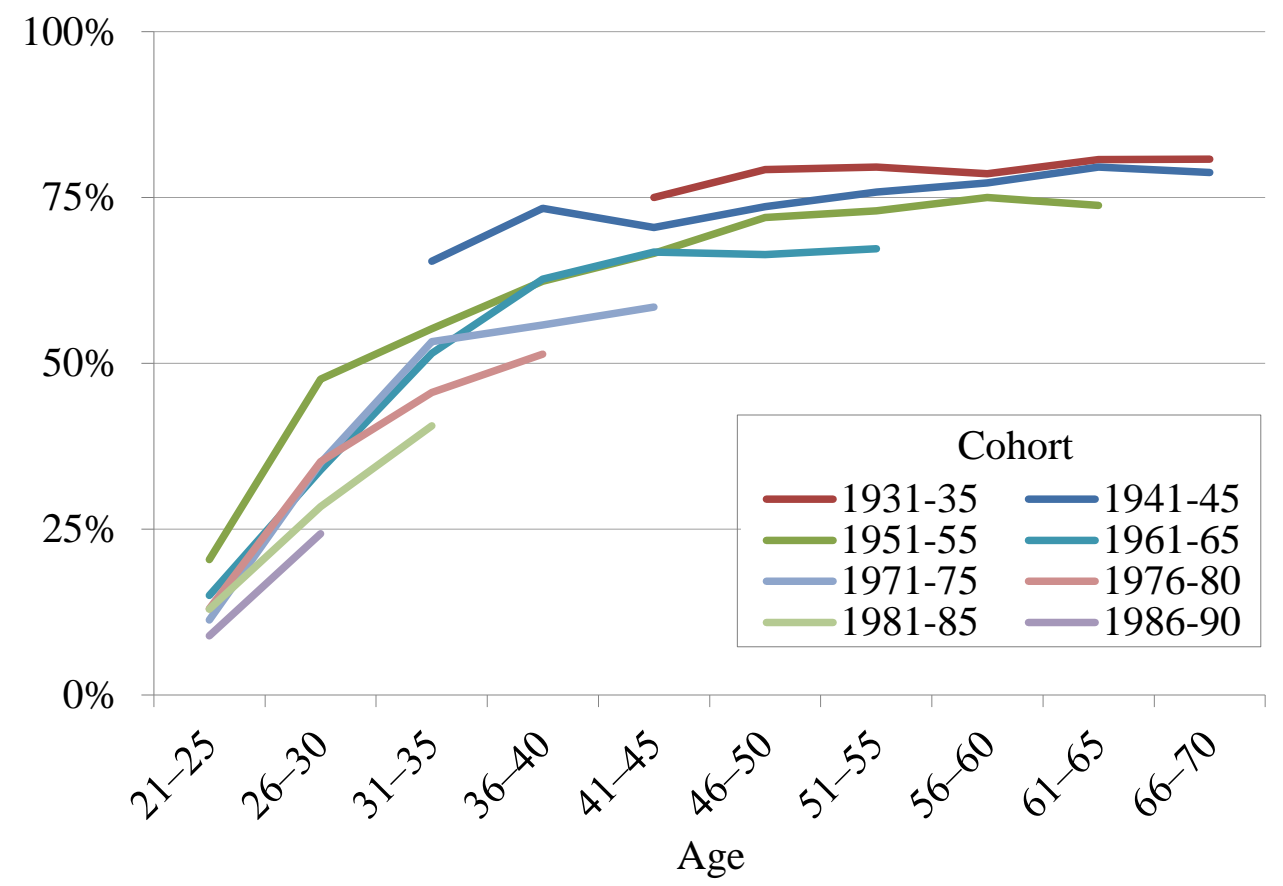

Note: Appendix Table 11 provides additional data.

Source: Authors' estimates from the Annual Social and Economic supplement to the Current Population Survey.

Figure 14. Median Per Capita Inflation-Adjusted Household Net Worth by Age and Birth Cohort

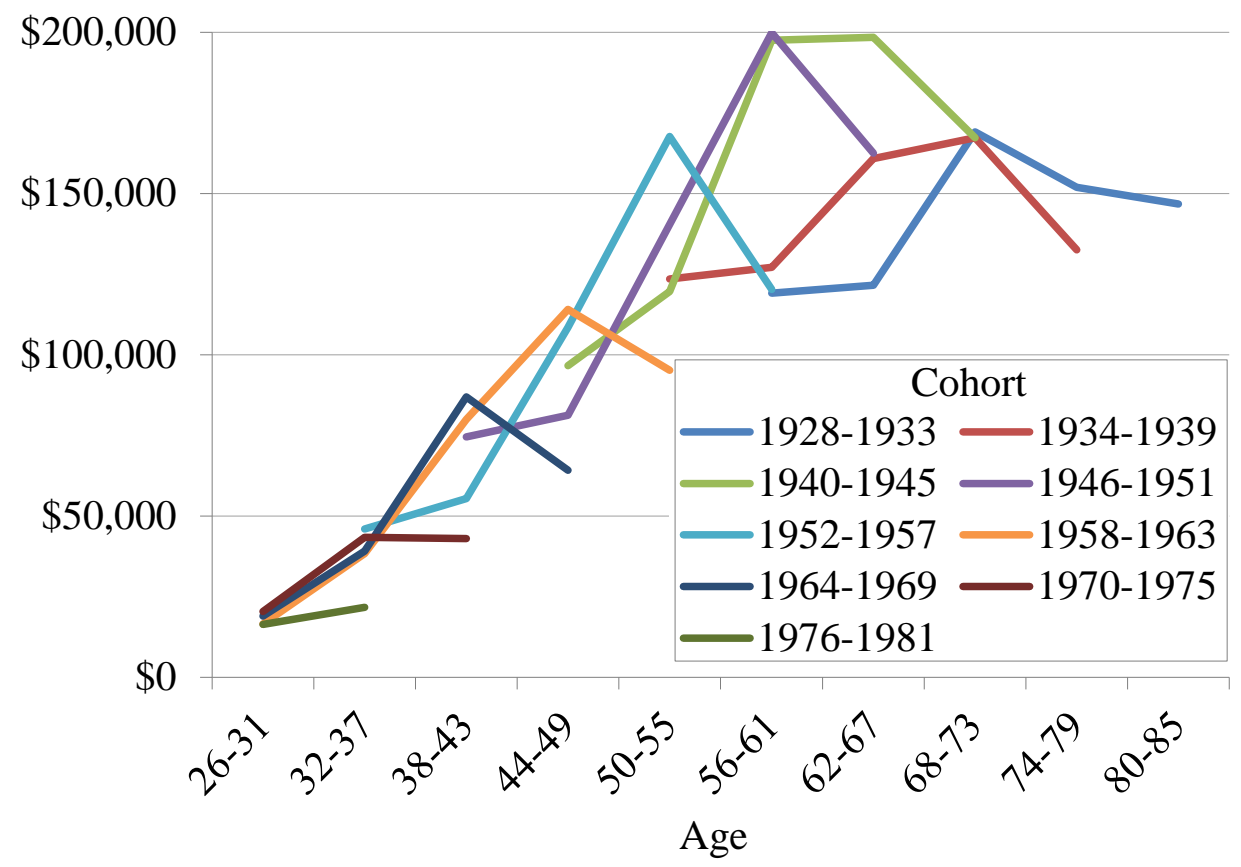

Note: Estimates are reported in constant 2015 dollars. The analysis divided household net worth by two for married adults. Appendix Table 12 provides additional data.

Source: Authors' tabulations from the Survey of Consumer Finances, 1983-2013. 
Figure 15. Share of Adults with Financial Assets, by Age and Birth Cohort

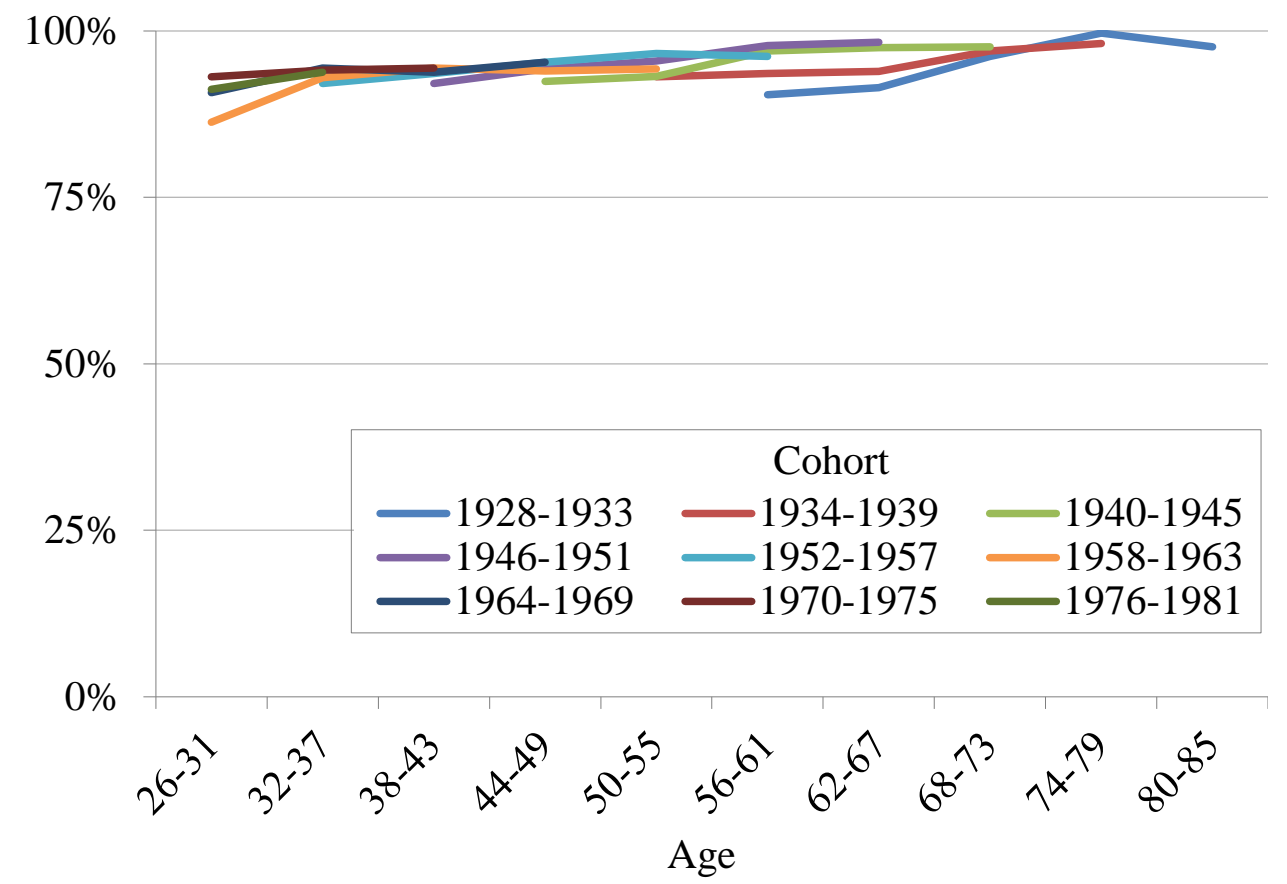

Note: Estimates include the value of retirement accounts. Appendix Table 13 provides additional data. Source: Authors' tabulations from the Survey of Consumer Finances, 1983-2013.

Figure 16. Median Per Capita Inflation-Adjusted Value of Financial Assets for Adults with Positive Holdings, by Age and Birth Cohort

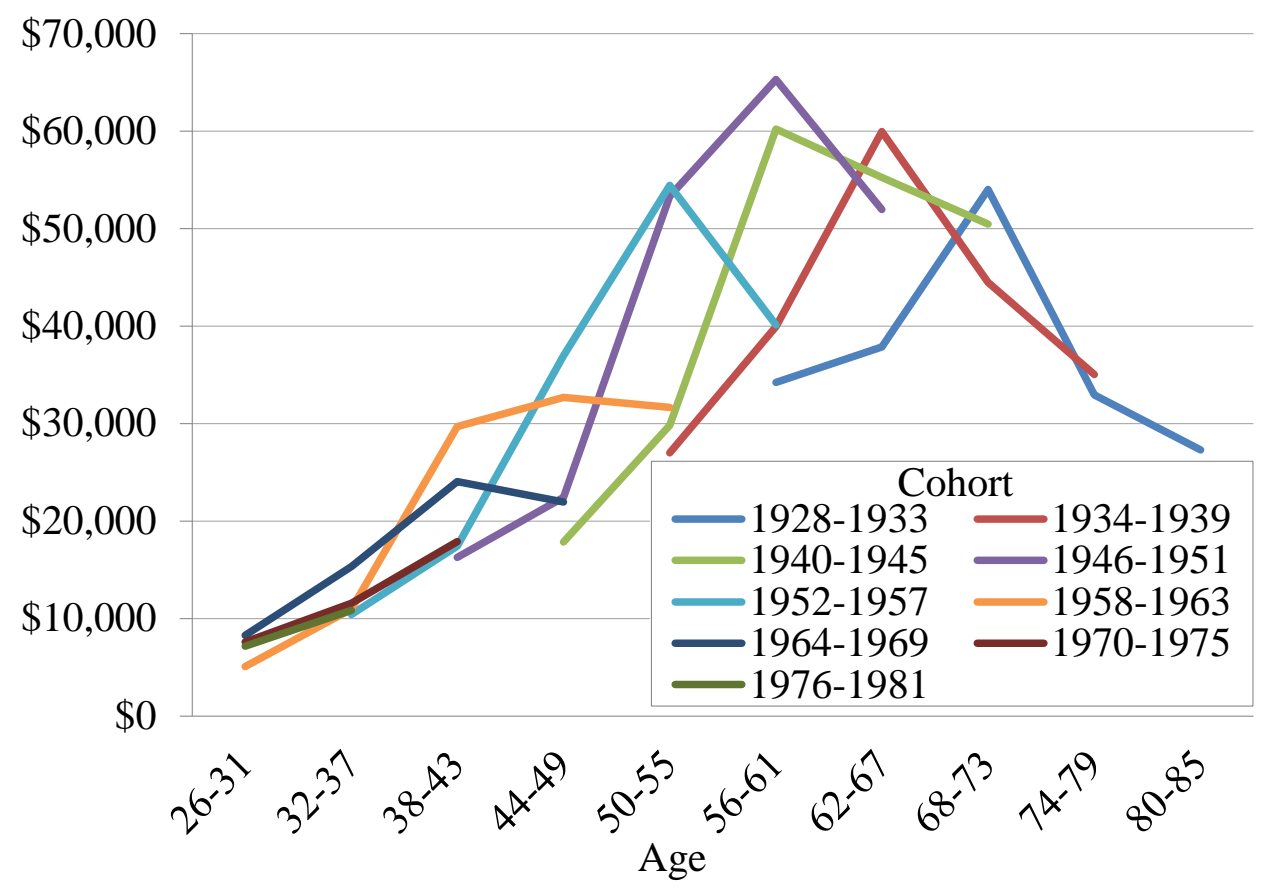

Note: Estimates are reported in constant 2015 dollars and include the value of retirement accounts. The analysis divided the value of financial assets by two for married adults. Appendix Table 14 provides additional data. Source: Authors' tabulations from the Survey of Consumer Finances, 1983-2013. 
Figure 17. Share of Adults with Retirement Accounts, by Age and Birth Cohort

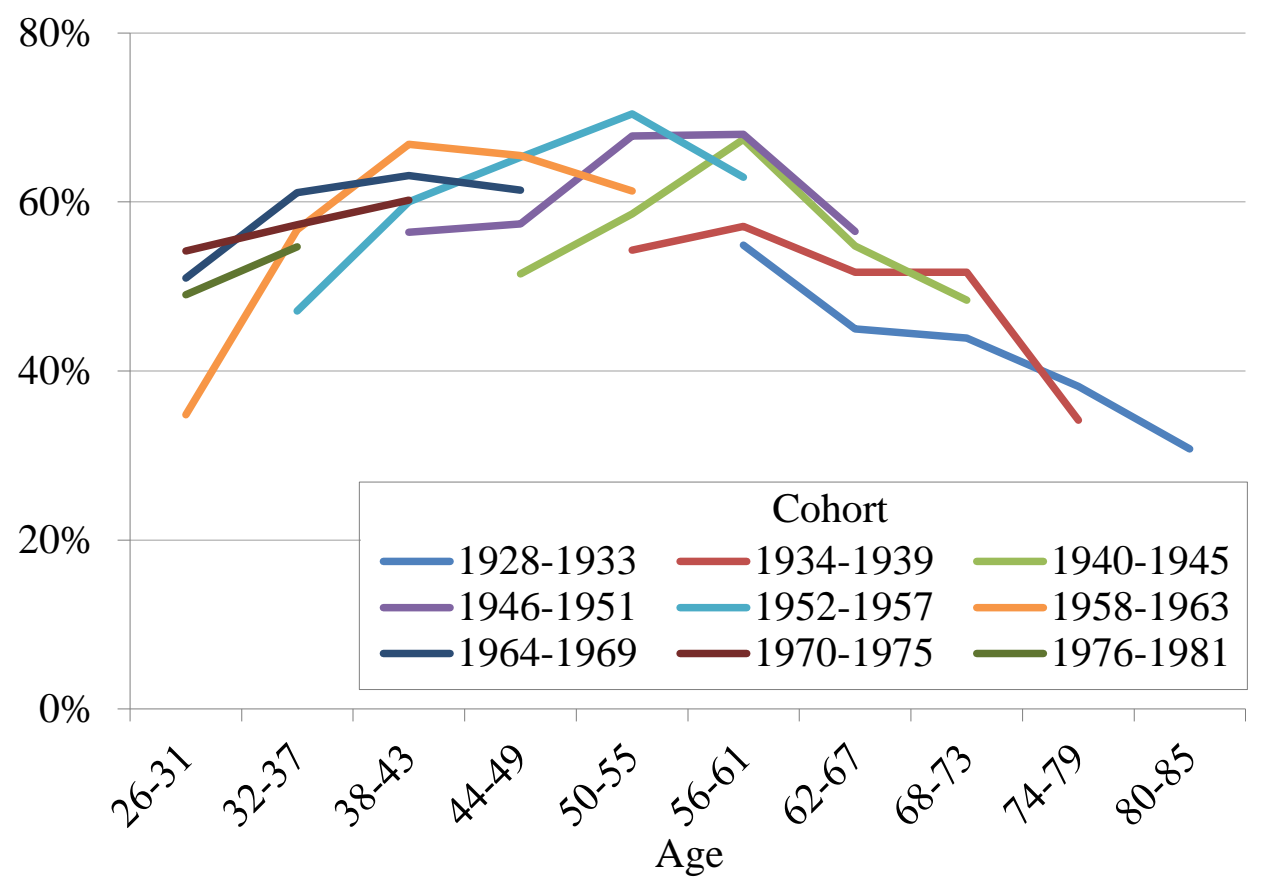

Note: Appendix Table 15 provides additional data.

Source: Authors' tabulations from the Survey of Consumer Finances, 1983-2013.

Figure 18. Median per Capita Inflation-Adjusted Value of Retirement Accounts for Accountholders, by Age and Birth Cohort

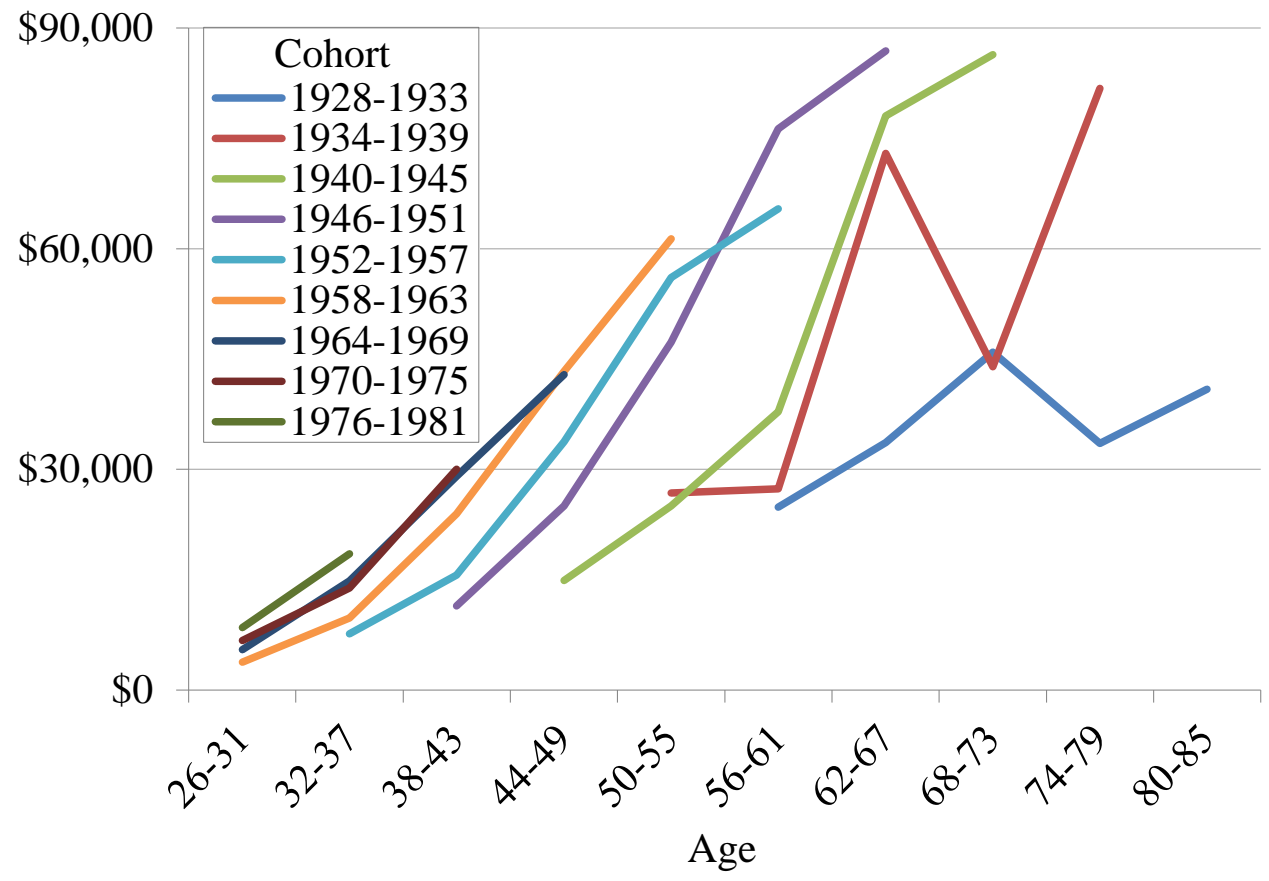

Note: Estimates are reported in constant 2015 dollars. The analysis divided the value of retirement accounts by two for married adults. Appendix Table 16 provides additional data.

Source: Authors’ tabulations from the Survey of Consumer Finances, 1983-2013. 
Figure 19. Share of Adults with Housing Wealth, by Age and Birth Cohort

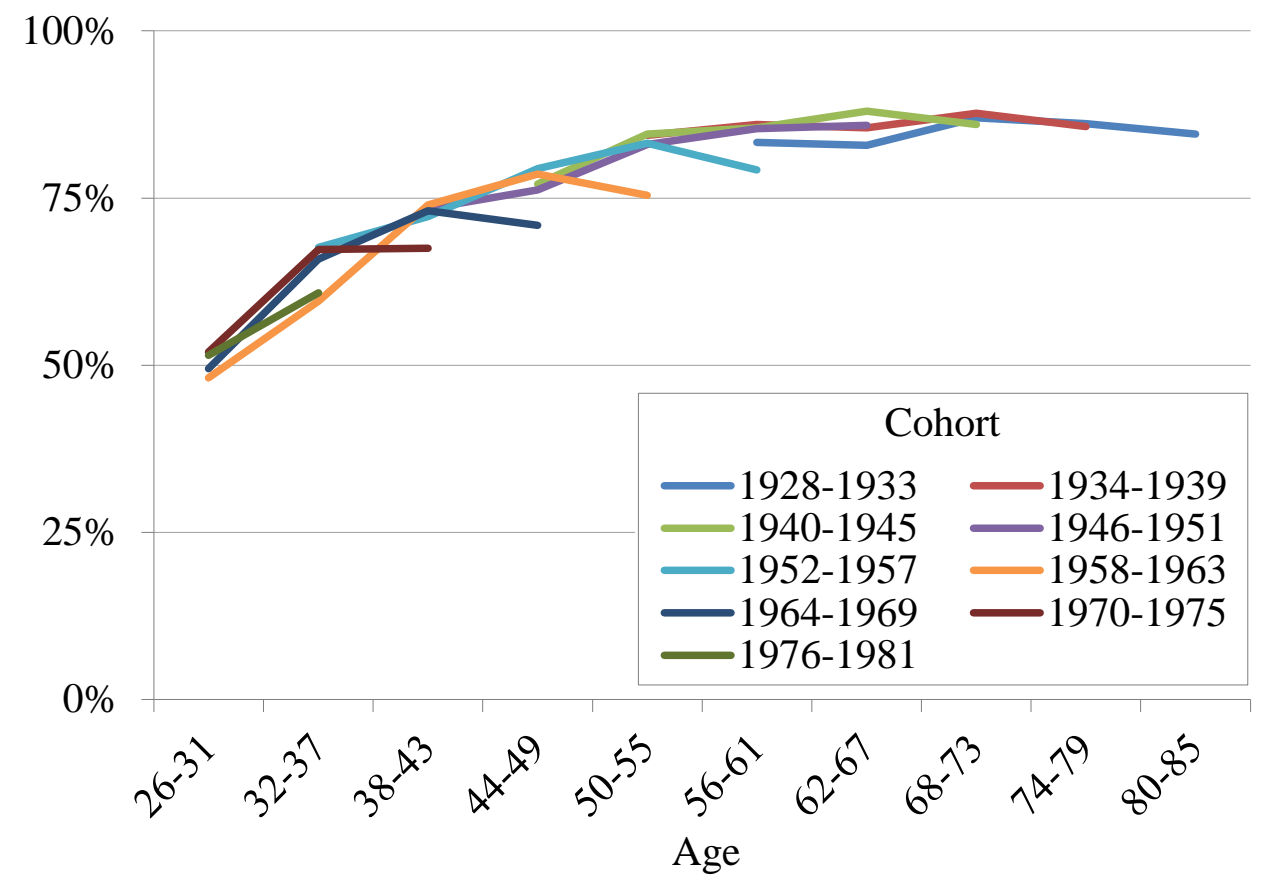

Note: Estimates refer to gross housing wealth. Net housing wealth, or home equity, was negative for people whose housing debt exceeded their housing wealth. Appendix Table 17 provides additional data.

Source: Authors' tabulations from the Survey of Consumer Finances, 1983-2013.

Figure 20. Median Per Capita Inflation-Adjusted Value of Housing Wealth for Adults with Housing Wealth, by Age and Birth Cohort

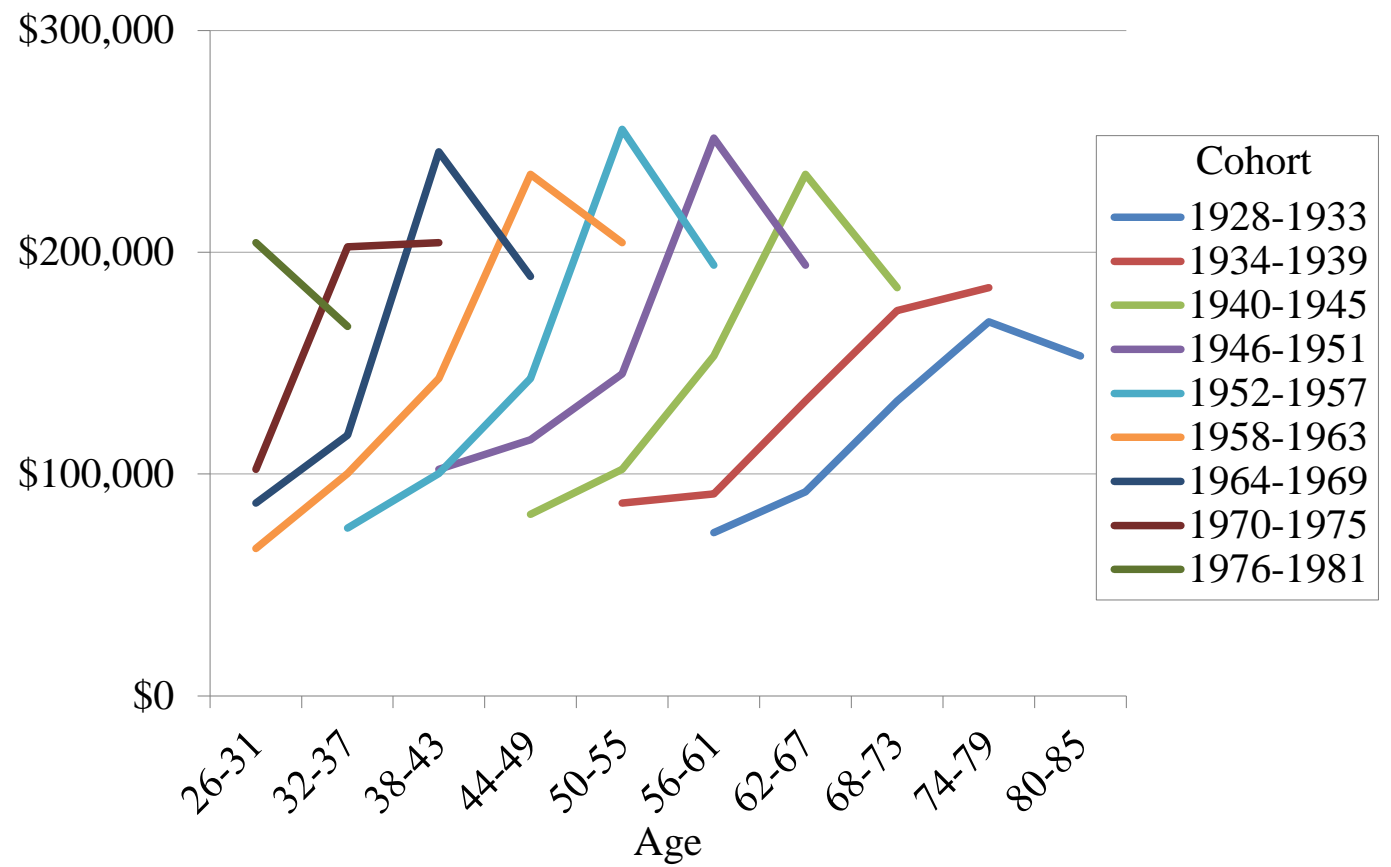

Note: Estimates are reported in constant 2015 dollars. The analysis divided housing wealth by two for married adults. Estimates refer to gross housing wealth. Net housing wealth, or home equity, was negative for people whose housing debt exceeded their housing wealth. Appendix Table 18 provides additional data.

Source: Authors' tabulations from the Survey of Consumer Finances, 1983-2013. 
Figure 21. Share of Adults with Outstanding Debt, by Age and Birth Cohort

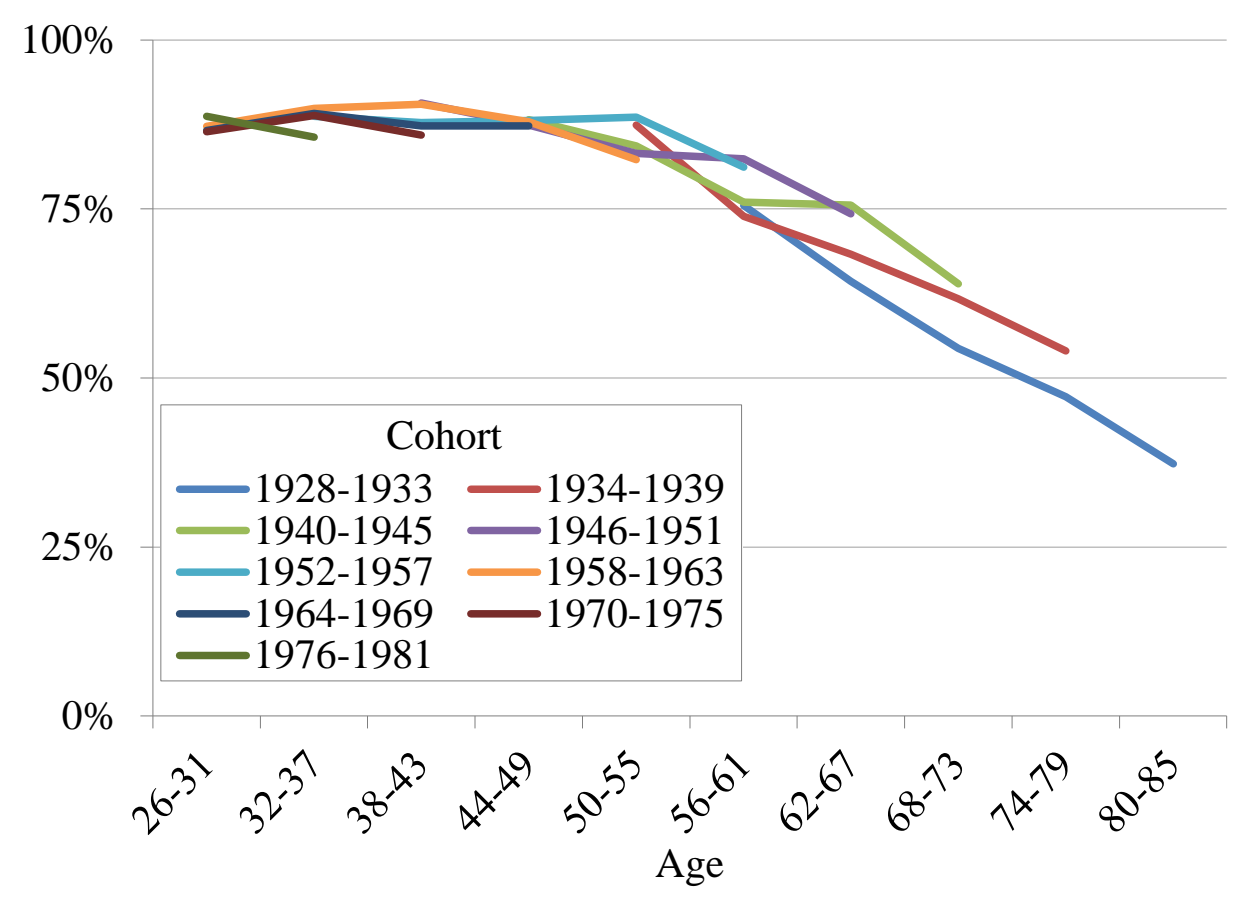

Note: Appendix Table 19 provides additional data.

Source: Authors' tabulations from the Survey of Consumer Finances, 1983-2013.

Figure 22. Median per Capita Inflation-Adjusted Value of Outstanding Debt for Debtholders, by Age and Birth Cohort

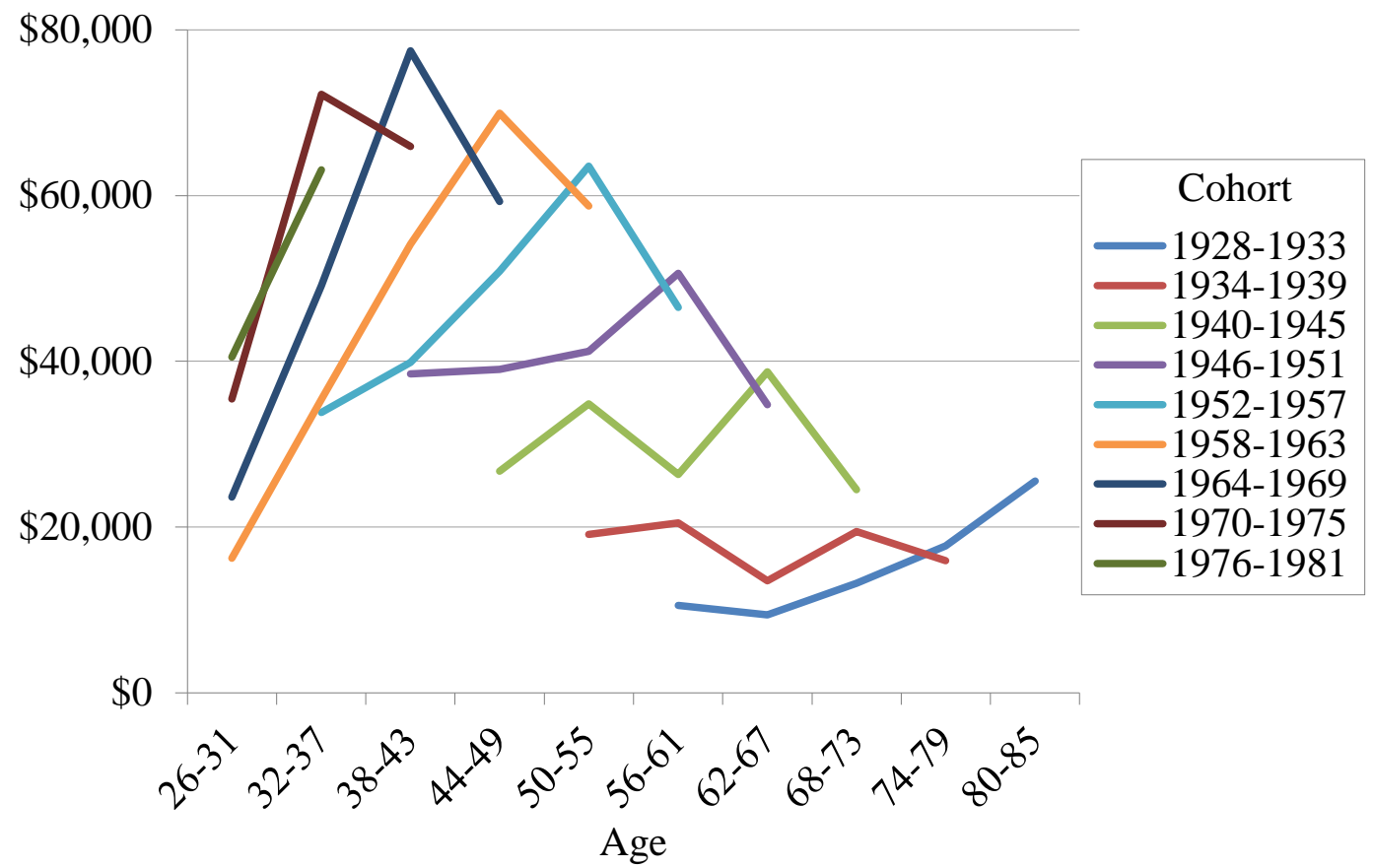

Note: Estimates are reported in constant 2015 dollars. The analysis divided household debt by two for married adults. Appendix Table 20 provides additional data.

Source: Authors' tabulations from the Survey of Consumer Finances, 1983-2013. 
Table 1. Projected Median Per Capita Inflation-Adjusted Annual Family Income at Age 70 by Birth Cohort, Sex, and Wage Growth Assumption

\section{$1936-45 \quad 1946-55 \quad 1956-65 \quad 1966-75 \quad 1976-85$}

Traditional Income Measure

Men and Women

High wage growth (1.2 percent per year)

Moderate wage growth $(0.81$ percent per year)

Low wage growth $(0.70$ percent per year)

33,000

35,000

33,000

36,000

38,000

33,000

35,000

33,000

34,000

36,000

33,000

35,000

33,000

34,000

35,000

Men

High wage growth (1.2 percent per year)

Moderate wage growth (0.81 percent per year)

36,000

37,000

36,000

38,000

40,000

36,000

37,000

35,000

36,000

37,000

Low wage growth ( 0.70 percent per year)

36,000

37,000

35,000

36,000

36,000

Women

High wage growth (1.2 percent per year)

30,000

33,000

31,000

34,000

37,000

Moderate wage growth ( 0.81 percent per year)

Low wage growth $(0.70$ percent per year)

30,000

33,000

31,000

32,000

34,000

30,000

33,000

30,000

32,000

33,000

Total Potential Income Measure

Men and Women

High wage growth (1.2 percent per year)

Moderate wage growth ( 0.81 percent per year)

37,000

40,000

38,000

40,000

43,000

37,000

40,000

37,000

38,000

39,000

Low wage growth (0.70 percent per year)

37,000

40,000

37,000

37,000

38,000

Men

High wage growth (1.2 percent per yea

Moderate wage growth (0.81 percent per year)

$40,000 \quad 42,000$

41,000

43,000

46,000

Low wage growth (0.70 percent per year)

40,000

42,000

40,000

41,000

42,000

40,000

42,000

40,000

40,000

41,000

Women

\begin{tabular}{llllll} 
High wage growth (1.2 percent per year) & 34,000 & 38,000 & 35,000 & 37,000 & 40,000 \\
Moderate wage growth (0.81 percent per year) & 34,000 & 38,000 & 35,000 & 35,000 & 37,000 \\
Low wage growth (0.70 percent per year) & 34,000 & 38,000 & 34,000 & 35,000 & 36,000 \\
\hline
\end{tabular}

Note: Estimates are reported in constant 2015 dollars and rounded to the nearest $\$ 1,000$. The traditional income measure includes earnings, Social Security, DB pensions, SSI, interest, dividends, rent, and occasional withdrawals from retirement accounts. The total potential income measure includes earnings, Social Security, DB pensions, SSI, and the annual income from an actuarially fair annuity valued at 80 percent of financial assets, including retirement accounts. The analysis divides total household income by two for married adults.

Source: Dynamic Simulation of Income Model 4, Run Numbers 942B, 942D, and 942E. 
Table 2. Projected Mean Per Capita Inflation-Adjusted Annual Family Income at Age 70, by Income Type, Income Quintile, and Birth Cohort

\begin{tabular}{lcrr}
\hline & $\mathbf{1 9 3 6 - 4 5}$ & $\mathbf{1 9 7 6 - 8 5}$ & Difference \\
\hline Bottom income quintile & & & \\
Social Security income & 8,300 & 10,100 & 1,800 \\
Earnings & 500 & 500 & 0 \\
Income from financial assets & 800 & 1,500 & 700 \\
DB pension income & 600 & 200 & -400 \\
SSI & 500 & 200 & -300 \\
Total & 10,700 & 12,500 & 1,800 \\
& & & \\
Middle income quintile & & & \\
Social Security income & 15,800 & 21,500 & 5,700 \\
Earnings & 6,000 & 7,000 & 1,000 \\
Income from financial assets & 7,100 & 9,500 & 2,400 \\
DB pension income & 7,800 & 1,100 & $-6,700$ \\
SSI & 0 & 0 & 0 \\
Total & 36,700 & 39,100 & 2,400 \\
& & & \\
Top income quintile & \multicolumn{3}{c}{} \\
$\quad$ Social Security income & 18,000 & 26,600 & 8,600 \\
Earnings & 34,100 & 77,700 & 43,600 \\
Income from financial assets & 47,900 & 47,500 & -400 \\
DB pension income & 25,500 & 4,700 & $-20,800$ \\
SSI & 0 & 0 & 0 \\
Total & 125,500 & 156,500 & 31,000 \\
\hline
\end{tabular}

Note: Estimates are reported in constant 2015 dollars and rounded to the nearest $\$ 100$. The tables shows mean total potential income, which includes earnings, Social Security, DB pensions, SSI, and the annual income from an actuarially fair annuity valued at 80 percent of financial assets, including retirement accounts. The analysis divides total household income by two for married adults. The projections assumed that future wage growth averaged 0.81 percent per year.

Source: Dynamic Simulation of Income Model 4, Run Numbers 942B, 942D, and 942E. 
Table 3. Percentage of Adults Whose Projected Age-70 Income Falls Short of a 75 Percent Replacement Rate, by Birth Cohort, Income Measure, and Wage Growth Assumption

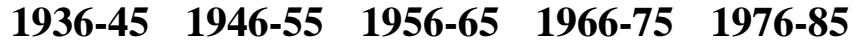

Traditional income measure

High wage growth (1.2 percent per year)

38

$39 \quad 36$

42

Moderate wage growth ( 0.81 percent per year)

38

40

37

39

37

44

44

Low wage growth ( 0.70 percent per year)

38

39

45

46

Total potential income measure

High wage growth (1.2 percent per year)

Moderate wage growth ( 0.81 percent per year) 32

$32 \quad 33$

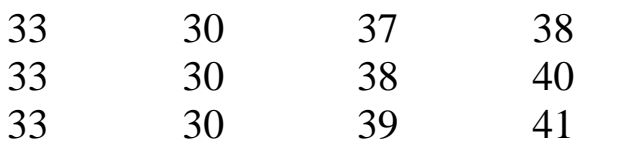

Note: Estimates are reported in constant 2015 dollars and rounded to the nearest \$1,000. The traditional income measure includes earnings, Social Security, DB pensions, SSI, interest, dividends, rent, and occasional withdrawals from retirement accounts. The total potential income measure includes earnings, Social Security, DB pensions, SSI, and the annual income from an actuarially fair annuity valued at 80 percent of financial assets, including retirement accounts. The analysis divides total household income by two for married adults.

Source: Dynamic Simulation of Income Model 4, Run Numbers 942B, 942D, and 942E. 


\section{Appendix}

This appendix describes how DYNASIM4 projects financial outcomes.

\section{Employment and Earnings}

DYNASIM projects the likelihood that an individual works each year as a function of age, sex, race/ethnicity, education, health and disability status, geographic region, marital status, student status, number of young children, spouse characteristics (employment, age, disability, and education), immigrant status, Social Security benefit status, cohort, and the state-specific unemployment rate. The likelihood also includes an estimated individual-specific error term that captures nonvarying individual preferences that are independent of observed characteristics. The model classifies an individual as employed if his or her expected probability of working exceeds a given random number. The selection criteria are adjusted so that our employment projections for men and women within particular age groups hit the trustees' targets. ${ }^{1}$

DYNASIM uses a similar set of explanatory variables to assign hourly wages and annual hours of work to those projected to work in the calendar year. Annual earnings are computed as the product of the hourly wage and annual hours worked. DYNASIM adjusts the underlying predicted annual wage for real wage growth based on the trustees' economic assumptions. It also aligns the annual earnings of workers to hit the Social Security trustees' annual earnings targets. The model has a special projection procedure for very high earners-those in the top one-tenth of 1 percent-because of the relatively high share of aggregate earnings that such earners garner.

The underlying price and wage targets from the Social Security trustees affect various other projections, including the Social Security wage base (the taxable maximum), the indexing of wages for the calculation of Social Security benefits, SSI benefit parameters, stock and bond rates of return, and interest rates. Changes in economic conditions also affect retirement and Social Security benefit claiming, as do marriage, divorce, fertility, and schooling outcomes. Income and Payroll Tax

DYNASIM calculates federal income tax liabilities by using an income tax calculator developed by Jon Bakija (Smith et al., 2007). The tax calculator uses annual projected tax unit

\footnotetext{
${ }^{1}$ The random error term follows an autoregressive process with a one-year lag so that random shocks include both new and lagged effects.
} 
income and assets from the SIPP panels matched to a Statistics of Income (SOI) data file that includes itemized deductions and other variables needed to calculate income tax. The tax calculator assumes current-law federal income tax rules, including the provisions in the American Tax Relief Act of 2012. Tax provisions affecting the treatment of Social Security benefits have not changed since 1993, but the share of Social Security benefits included in taxable income is continually increasing under current law partly because the threshold levels for including benefits in taxable income are not indexed for inflation. Other than the Social Security thresholds, DYNASIM inflates thresholds by projected changes in the consumer price index. DYNASIM also calculates Social Security coverage and annual payroll taxes by using currentlaw payroll tax rates. Only earnings in Social Security-covered employment are subject to payroll taxes.

\section{Retirement Accounts}

DYNASIM projects retirement accounts based on annual contributions to investment accounts and accumulated investment returns. DYNASIM starts with the self-reported SIPP

retirement account balances. Because of documented deficiencies in the SIPP asset data (Czajka, Jacobson, and Cody, 2003; Smith, Favreault, and Cashin, 2005), asset balances in retirement accounts—as well as financial assets outside of retirement accounts—in DYNASIM's starting SIPP sample are adjusted to align with asset distributions from the 2007 SCF.

DYNASIM grows stock, long-term corporate bond, and long-term government bond portfolios by using historical price changes and returns through 2015. Investment experience varies for each individual because the model sets rates of return stochastically, using historical means and standard deviations. The model accounts for the 2008 stock market crash, which reduced equity values by 37 percent, by assuming the market recovers to half its projected precrash value by 2017 (Butrica, Smith, and Toder, 2009, 2010). DYNASIM implements this assumption by using historic returns through 2015 and assumes a 7.42 percent average real rate of return on stocks from 2016 to 2017 before stocks resume their historic average real return of 6.5 percent after 2017. DYNASIM assumes mean real rates of return of 3.5 percent for corporate bonds, 3.0 percent for government bonds, and standard deviations of 17.28 percent for 
stocks and 2.14 percent for bonds. ${ }^{2}$ The 6.5 percent real return on stocks reflects a capital appreciation of about 3.5 percent and a dividend yield of around 3.0 percent, in line with the long-term performance of the S\&P 500. The model subtracts one percentage point from annual stock and bond returns to reflect administrative costs.

Individuals are assigned an individual-specific risk tolerance based on SCF data. An individual's share of retirement account assets invested in equities varies by age and risk tolerance, with high-risk and younger individuals investing more in equities than low-risk and older individuals.

DYNASIM assigns a growing share of workers to invest in target-date funds over time by using prevalence rates from the Employee Benefits Research Institute (Copeland, 2011). DYNASIM assigns target-date investors to specific target-date funds based on the dollarweighted share of the 40 largest target-date funds (Morningstar, 2012, table 3). Workers with target-date funds use the stock and bond portfolio mix of their assigned fund at each age. All investors rebalance portfolios annually to preserve the target mix of stocks and bonds.

DYNASIM assumes 40 percent of firms offering DC plans implement automatic enrollment beginning in 2008. Automatic enrollment increases the probability new hires will participate in DC plans in the first year on the job, but workers can still opt out. Automatic enrollment affects new hire participation, but the participation probability is higher for workers who contributed in a prior year, so automatic enrollment increases participation on average beyond the first year on the job.

DYNASIM allows some workers to cash out retirement account balances with job changes or job losses. Younger workers, workers with lower account balances, and workers who lose their jobs are more likely to cash out retirement account balances than are older workers, those with higher balances, and those who move from one job to another without a break in employment. High unemployment contributes to lower lifetime DC pension savings through workers' hardship withdrawals and loss of contributions (and lost returns on those lost contributions) when out of work.

\footnotetext{
${ }^{2}$ The standard deviations are derived from real returns over the 58-year period between 1952 and 2010 for largecompany stocks and Treasury bills as reported in Ibbotson Associates (2014). Inflation assumptions follow the 2016 intermediate assumptions used by the Social Security trustees (Board of Trustees, Federal Old-Age and Survivors Insurance and Federal Disability Insurance Trust Funds, 2016).
} 
DYNASIM's pension projections allow the user to select alternate future pension assumptions including a more rapid shift from DB pensions to DC pensions as well as expansions of DC plans to firms not currently offering pensions (Butrica and Smith, 2016). Users can specify investment choice (Roth IRA, traditional IRA, 401k), firm size thresholds, default investment rate, share of participants that select the default investment, portfolio allocation (target-date fund, Treasury G fund, blend of stocks and bonds).

\section{Financial Assets}

DYNASIM uses random-effects models developed for the Social Security Administration's (SSA) MINT model to project financial assets. DYNASIM starts with SIPP self-reported assets (saving, checking, and money market accounts; certificates of deposit; stocks; bonds; and equity in businesses, vehicles, and nonhome real estate, less unsecured debt). As with retirement accounts, we adjust the SIPP starting values to align with the household asset distribution from the 2007 SCF.

Financial assets accumulate and decumulate as a function of family characteristics and earnings and projected wage differentials. The main economic explanatory variable is the individual's lifetime earnings relative to the cohort average. Individuals with above-average lifetime earnings accumulate assets faster than those with below-average lifetime earnings. A spell of unemployment will lower a worker's average compared with a worker who remains employed continuously. The longer the unemployment spell, the greater is the differential in lifetime earnings relative to the cohort average, and the greater is the impact on projected assets. Assets accumulate at the family level, so husbands and wives equally share family assets. We assume couples split assets at divorce and survivors inherit the assets of deceased spouses.

DYNASIM projects nonpension financial assets over three age ranges: up to age 50, from 51 to retirement, and from retirement to death. Equations projecting assets to age 50 were estimated based on the PSID (Toder et al., 2002). Equations projecting assets from age 51 to retirement were estimated on the first seven waves of the Health and Retirement Study (HRS) (Smith et al., 2007). Equations projecting assets from retirement to death were estimated on a synthetic panel of SIPP data (Toder et al., 1999). The latter two datasets include historic earnings from the SSA's summary earnings records data. 
Asset decumulation includes simulated sharp reductions in assets associated with health shocks, institutionalization, and end of life.

\section{Homeownership}

DYNASIM starts with self-reported homeownership status. Nonhomeowners are subject to an annual home purchase logistic hazard model. Homeowners are subject to an annual home sale logistic hazard model. The home purchase and sale hazard models were estimated on 19842013 PSID from age 25 until death. The home purchase model includes age, lifetime earnings, recent earnings, marital status, education, and number of children. It also included the ratio of median state home value to national median home value and an indicator for whether the family lives in metro area with 1 million or more people (defined in 2014 American Community Survey data). The home sale model includes age, sex, lifetime earnings, recent earnings, age, marital status, divorce duration, first child indicator, and number of children under age 18.

\section{Home Equity}

As with financial assets, DYNASIM uses random-effects models developed for the SSA's MINT model to project home equity among homeowners. DYNASIM starts with SIPP self-reported home equity. These models project home equity over three age ranges: 25 to 50, 51 to 70 , and 71 to death. Equations projecting home equity to age 50 were estimated based on the PSID (Toder et al., 2002). Equations projecting equity from age 51 to 70 were estimated based on the first seven waves of the HRS (Smith et al., 2007). DYNASIM holds real home equity constant after age 70 for individuals who continue to own their homes.

\section{Retirement Income}

DYNASIM projects income from various other sources to generate a measure of total household income. Social Security income is computed based on the benefit formula, projected lifetime earnings, marriage history, and an equation projecting benefit take-up. DYNASIM projects retirement plan coverage and participation, plan contributions, and payments from employer-sponsored DB pension plans, cash balance plans, and retirement accounts based on equations of job change. DYNASIM also projects asset income as a function of projected assets. 
Finally, DYNASIM calculates SSI for eligible individuals based on total family income, assets, and state-specific program rules.

\section{Pensions}

DYNASIM projects pensions from employer-sponsored DB plans, cash balance plans, and retirement accounts, including 401(k) and 403(b) plans, Keoghs, and IRAs. Starting information about pension coverage on current and past jobs, pension contribution rates, and account balances comes from SIPP self-reported information. DYNASIM projects employer characteristics and employer benefits (pensions and health insurance) at each simulated job change.

DYNASIM projects private DB pensions by using DB plan formulas from the Pension Benefit Guaranty Corporation's pension insurance modeling system (PIMS). These DB plan formulas are randomly assigned to DB participants based on broad industry, union status, and firm size categories, as well as an indicator of whether the firm offers both DB and DC plans. For government pensions, DYNASIM uses actual benefit formulas to calculate benefits for federal government workers and military personnel; to estimate pension benefits for state and local government workers, DYNASIM assigns workers to one of 481 state and local government pensions from the Urban Institute's State and Local Employee Pension Plan (SLEPP) database based on the workers’ state and job sector (Urban Institute, 2016).

Projected DB pension information reflects pension plan structures through December 2008, including DB pension plan freezes and conversions to cash balance plans. ${ }^{3}$ DYNASIM assumes all nonunion private-sector DB pensions will experience a hard freeze between 2008 and 2016 and also assumes two-thirds of state and local pensions will experience a soft freeze between 2008 and 2016. ${ }^{4}$ (Users can run alternative scenarios by changing these assumptions.)

DYNASIM adjusts worker DB pensions and survivor pensions after initial pension receipt for cost-of-living adjustments. DYNASIM varies the probability of selecting a joint and survivor annuity by gender, education, family health status, wealth, and expected pension

\footnotetext{
${ }^{3}$ DYNASIM projects conversions of pension plan type (from DB to cash balance or DB to DC) by using actual plan change information for plans included in the PIMS data through 2008.

${ }^{4}$ In a hard freeze, all workers cease accruing DB benefits and the firm switches to a DC plan. In a soft freeze, new workers are offered a DC plan instead of DB plan, and existing workers remain in the DB plan and continue to accrue benefits.
} 
income. It also varies DB cost-of-living adjustments by employment sector (i.e., private, federal government, and state and local government).

Most DB plan formulas assign pension income as a function of workers' earnings and job tenure. DB pension benefits are capped by the statutory limitations under Section 415(b)(1)(A). Most private-sector workers must complete five years of service before they vest in the DB plan. Changes in job tenure directly affect expected DB pension income.

\section{Social Security}

DYNASIM includes a detailed Social Security benefit calculator that accounts for virtually all benefit provisions under current law (scheduled and payable). The benefit calculator can also modify many of the current law provisions to simulate Social Security reforms, including changes in the benefit formula, payroll taxes and the wage cap, changes in the early and full retirement ages, cost of living adjustments, spouse and survivor provisions, minimum benefits, and changes to the windfall elimination provisions (WEP) and Government pension offsets (GPO).

\section{Means-Tested and Nonmeans-Tested Benefits}

DYNASIM projects means-tested and nonmeans-tested benefits using models estimated for MINT6 and MINT7 (Smith et al, 2010). Means-tested benefits include payments from the Temporary Assistance for Needy Families program. Nonmeans-tested benefits include veterans' benefits, unemployment insurance, and workers’ compensation payments. DYNASIM starts with self-reported receipt and benefit amounts from the SIPP. It then models annual transitions separately for prior year beneficiaries and prior-year nonbeneficiaries. Means-tested and nonmeans-tested benefits depend on lagged benefit status, lagged SSI receipt, age, marital status, education, health status, number of children, financial assets, longitudinal earnings, and a measure of a change in earnings or impending death. DYNASIM first project benefit receipt and then benefit amounts among beneficiaries.

\section{Total Retirement Income}

DYNASIM projects income and assets annually from 2006 to 2087 by age, gender, marital status, race and ethnicity, poverty status, geographic region, educational attainment, per 
capita lifetime work years, nativity, and per capita income quintile. Results can be summarized for any individual year and in numerous ways. Typically income and assets are measured on a per capita basis in current price-adjusted dollars. Per capita values are half the sum of husband's and wife's values for married individuals and own values for single individuals. Our measure of per capita lifetime work years is the sum of years with positive earnings since $1951 .{ }^{5}$ In years when both the husband and wife have positive earnings, both partners get one year of work credit. If only one partner works, both partners get half a year of work credit. If neither partner works, both partners get zero work credits. Single individuals get work credits based on their own earnings in years they are single. DYNASIM also calculates the income of nonspouse family members, which is used only for calculating poverty status.

DYNASIM can generate three per capita income measures (census, annuity, and return income) that vary by the asset income source and by the inclusion of imputed rental income. Per capita income is the sum of the husband's and wife's income divided by two for married individuals and own income for single individuals. DYNASIM can also calculate equivalent income that uses the family size parameters used to determine supplemental poverty to adjust for family size (Short and Garner, 2012). The model also can use these optional measures in replacement rate calculations based on the highest 35 years of earnings between ages 20 and 70 or the average of earnings received between ages 50 and 54. Poverty measures used to assess well-being in retirement also include the income of nonspouse family members.

Census income is the sum of per capita earnings, Social Security, SSI, DB pension, interest, dividends, net rental income, means-tested and nonmeans-tested benefits, and retirement account withdrawals. Except for the per capita conversion, this is the standard measure the U.S. Census Bureau uses to calculate personal income. The census income poverty rate includes family census income (including nonspouse family members) divided by the family poverty threshold. Equivalent income uses census income divided by the family equivalence factor (relative to a two-adult, two-child family).

Annuity income is the sum of per capita earnings, Social Security, SSI, DB pension, and annuitized asset income. The annuity income poverty rate uses family annuity income (including nonspouse family members) divided by the family poverty threshold.

\footnotetext{
${ }^{5}$ Early cohorts have censored work years because DYNASIM4's earnings data begin in 1951. We do not measure work years before 1951 .
} 
The annuitized asset income measure calculates income from retirement accounts and financial assets each year as the real (price-indexed), actuarially fair annuity income a family would receive if it annuitized 80 percent of its retirement accounts and other financial assets (using a 3 percent annual real return). The annuity factor is recalculated each year to reflect changes in wealth as individuals age, based on DYNASIM projections of wealth accumulation and spenddown and changes in life expectancy and marital status as individuals survive to older ages. For married couples, DYNASIM assumes a 50 percent survivor annuity.

The annuity measure ensures comparability with DB pension and Social Security benefits, which are also annuities. Without this type of adjustment, DYNASIM would overstate the loss in retirement well-being from the shift from DB pension income to DC assets. A dollar in DB pension wealth produces more income by standard measures than a dollar in DC wealth because measured DB income counts both a return on accumulated assets and some return of principal, but measured income from financial wealth includes only the return on accumulated assets and realized retirement account withdrawals. The annuity measure differs conceptually from the Census measure, which includes only the rate of return on assets (interest, dividends, and rental income) and excludes the potential consumption of capital that could be realized if a person spent down his or her wealth. ${ }^{6}$

Return income is the sum of per capita earnings, Social Security, SSI, DB pension, and a 6 percent return on retirement and financial assets. The return income poverty rate includes family return income (including nonspouse family members) divided by the family poverty threshold.

The return income measure provides a measure of well-being from both incomegenerating assets (like stocks, bonds, and savings accounts) and non-income-generating assets (like vehicles and vacation property), but it does not include a factor based on life expectancy. A problem with the annuity measure is that it typically shows asset income increasing with age because the remaining assets support fewer years of remaining life. In reality, the assets of seniors generally decline with age. The return measure captures this pattern. Unlike the Census measure, which excludes asset values inside of retirement accounts unless they are withdrawn, the return income includes notional returns on retirement accounts.

\footnotetext{
${ }^{6}$ We calculate annuitized retirement accounts and financial (nonpension) assets by using the same annuity factors.
} 
The model optionally captures the amount by which homeowners are better off than those without any home equity. DYNASIM imputes a 3 percent rate of return to housing equity (imputed rent) that represents the savings in rent from owning a home, net of costs of interest and home maintenance. DYNASIM does not project the rapid increase in home values between 2004 and 2006, nor does it project the rapid decline in home values between 2006 and 2009. ${ }^{7}$ Instead, it projects steadier, smoothed growth in home equity through this period based on PSID and HRS estimated models of home equity. It accounts for the housing bubble and bust by using an out-of-the-model adjustment calculated from the 2006-2014 American Community Survey data at the state-level.

\footnotetext{
${ }^{7}$ Standard \& Poor's. 2011. S\&P/Case-Schiller Home Price Indices. http://us.spindices.com/index-family/realestate/sp-case-shiller.
} 
Appendix Table 1. Men’s Labor Force Participation Rates, by Age and Birth Cohort (\%)

\begin{tabular}{lrrrrrrrrrr}
\hline & \multicolumn{10}{c}{ Age } \\
\cline { 2 - 11 } & $\mathbf{2 1 - 2 5}$ & $\mathbf{2 6 - 3 0}$ & $\mathbf{3 1 - 3 5}$ & $\mathbf{3 6 - 4 0}$ & $\mathbf{4 1 - 4 5}$ & $\mathbf{4 6 - 5 0}$ & $\mathbf{5 1 - 5 5}$ & $\mathbf{5 6 - 6 0}$ & $\mathbf{6 1 - 6 5}$ & $\mathbf{6 5 - 7 0}$ \\
\hline $\mathbf{1 9 3 1 - 3 5}$ & & & 97.7 & 96.7 & 94.3 & 92.0 & 88.1 & 77.0 & 47.2 & 28.0 \\
$\mathbf{1 9 3 6 - 4 0}$ & & 97.3 & 97.2 & 95.5 & 94.2 & 92.1 & 87.4 & 75.4 & 50.4 & 29.1 \\
$\mathbf{1 9 4 1 - 4 5}$ & 87.9 & 95.8 & 96.2 & 95.2 & 93.2 & 91.9 & 84.4 & 74.4 & 53.6 & 36.0 \\
$\mathbf{1 9 4 6 - 5 0}$ & 84.7 & 94.6 & 96.5 & 94.4 & 93.6 & 90.5 & 85.3 & 75.0 & 54.5 & 33.9 \\
$\mathbf{1 9 5 1 - 5 5}$ & 86.4 & 94.0 & 94.4 & 94.5 & 90.4 & 89.5 & 84.1 & 76.5 & 57.9 & \\
$\mathbf{1 9 5 6 - 6 0}$ & 87.3 & 93.6 & 93.4 & 91.6 & 91.7 & 89.0 & 83.5 & 75.6 & & \\
$\mathbf{1 9 6 1 - 6 5}$ & 87.6 & 93.0 & 93.3 & 92.9 & 90.5 & 87.4 & 83.4 & & & \\
$\mathbf{1 9 6 6 - 7 0}$ & 85.6 & 92.8 & 93.5 & 91.7 & 89.3 & 87.4 & & & & \\
$\mathbf{1 9 7 1 - 7 5}$ & 85.0 & 91.8 & 92.6 & 91.3 & 89.8 & & & & & \\
$\mathbf{1 9 7 6 - 8 0}$ & 84.5 & 90.3 & 90.7 & 89.3 & & & & & & \\
$\mathbf{1 9 8 1 - 8 5}$ & 82.4 & 88.2 & 90.1 & & & & & & & \\
$\mathbf{1 9 8 6 - 9 0}$ & 77.4 & 88.3 & & & & & & & &
\end{tabular}

Note: The labor force participation rate is the share of the civilian noninstitutionalized population that is working or looking for work.

Source: Authors' estimates from the Annual Social and Economic supplement to the Current Population Survey.

Appendix Table 2. Women's Labor Force Participation Rates, by Age and Birth Cohort (\%)

\begin{tabular}{lcccccccccc}
\hline & \multicolumn{10}{c}{ Age } \\
\cline { 2 - 11 } & $\mathbf{2 1 - 2 5}$ & $\mathbf{2 6 - 3 0}$ & $\mathbf{3 1 - 3 5}$ & $\mathbf{3 6 - 4 0}$ & $\mathbf{4 1 - 4 5}$ & $\mathbf{4 6 - 5 0}$ & $\mathbf{5 1 - 5 5}$ & $\mathbf{5 6 - 6 0}$ & $\mathbf{6 1 - 6 5}$ & $\mathbf{6 5 - 7 0}$ \\
\hline $\mathbf{1 9 3 1 - 3 5}$ & & & 40.2 & 51.5 & 58.1 & 64.5 & 60.8 & 52.8 & 34.5 & 18.0 \\
$\mathbf{1 9 3 6 - 4 0}$ & & 37.4 & 46.9 & 58.4 & 67.0 & 68.1 & 64.9 & 55.9 & 37.3 & 20.8 \\
$\mathbf{1 9 4 1 - 4 5}$ & 48.2 & 44.7 & 54.4 & 66.4 & 72.3 & 73.8 & 70.3 & 59.6 & 42.0 & 25.2 \\
$\mathbf{1 9 4 6 - 5 0}$ & 55.5 & 57.1 & 66.9 & 72.8 & 78.1 & 77.3 & 72.4 & 63.5 & 47.0 & 25.7 \\
$\mathbf{1 9 5 1 - 5 5}$ & 64.1 & 66.9 & 71.4 & 75.3 & 78.5 & 79.0 & 73.3 & 65.3 & 47.1 & \\
$\mathbf{1 9 5 6 - 6 0}$ & 69.3 & 70.9 & 73.6 & 76.9 & 79.1 & 77.2 & 72.3 & 65.6 & & \\
$\mathbf{1 9 6 1 - 6 5}$ & 72.0 & 73.2 & 74.1 & 77.7 & 77.3 & 76.0 & 72.4 & & & \\
$\mathbf{1 9 6 6 - 7 0}$ & 70.8 & 75.1 & 75.7 & 74.7 & 76.7 & 75.3 & & & & \\
$\mathbf{1 9 7 1 - 7 5}$ & 72.7 & 76.1 & 73.2 & 75.1 & 74.9 & & & & & \\
$\mathbf{1 9 7 6 - 8 0}$ & 74.8 & 73.7 & 73.2 & 74.9 & & & & & & \\
$\mathbf{1 9 8 1 - 8 5}$ & 71.4 & 73.5 & 73.0 & & & & & & \\
$\mathbf{1 9 8 6 - 9 0}$ & 70.2 & 75.1 & & & & & & & \\
\hline
\end{tabular}

Note: The labor force participation rate is the share of the civilian noninstitutionalized population that is working or looking for work.

Source: Authors' estimates from the Annual Social and Economic supplement to the Current Population Survey. 
Appendix Table 3. Men’s Full-Time Employment Rates (\%)

\begin{tabular}{lcccccccccc}
\hline & \multicolumn{10}{c}{ Age } \\
\cline { 2 - 11 } & $\mathbf{2 0 - 2 4}$ & $\mathbf{2 5 - 2 9}$ & $\mathbf{3 0 - 3 4}$ & $\mathbf{3 5 - 3 9}$ & $\mathbf{4 0 - 4 4}$ & $\mathbf{4 5 - 4 9}$ & $\mathbf{5 0 - 5 4}$ & $\mathbf{5 5 - 5 9}$ & $\mathbf{6 0 - 6 4}$ & $\mathbf{6 5 - 6 9}$ \\
\hline $\mathbf{1 9 3 1 - 3 5}$ & & & 95.8 & 95.9 & 92.2 & 89.5 & 85.8 & 74.7 & 43.7 & 20.3 \\
$\mathbf{1 9 3 6 - 4 0}$ & & 94.4 & 95.7 & 93.1 & 92.1 & 88.2 & 83.4 & 71.0 & 46.3 & 21.7 \\
$\mathbf{1 9 4 1 - 4 5}$ & 85.4 & 93.7 & 93.5 & 92.7 & 90.3 & 88.4 & 81.9 & 71.6 & 48.4 & 25.7 \\
$\mathbf{1 9 4 6 - 5 0}$ & 79.8 & 90.5 & 93.1 & 90.2 & 90.0 & 87.8 & 82.6 & 71.2 & 48.2 & 26.4 \\
$\mathbf{1 9 5 1 - 5 5}$ & 78.7 & 89.0 & 89.8 & 90.3 & 86.5 & 87.2 & 79.6 & 69.2 & 52.4 & \\
$\mathbf{1 9 5 6 - 6 0}$ & 81.0 & 87.3 & 88.9 & 87.9 & 89.3 & 85.4 & 75.7 & 70.5 & & \\
$\mathbf{1 9 6 1 - 6 5}$ & 76.7 & 87.5 & 87.7 & 90.4 & 86.4 & 79.0 & 79.0 & & & \\
$\mathbf{1 9 6 6 - 7 0}$ & 76.1 & 85.2 & 90.3 & 87.7 & 80.7 & 82.3 & & & & \\
$\mathbf{1 9 7 1 - 7 5}$ & 72.7 & 87.0 & 87.8 & 82.2 & 84.2 & & & & & \\
$\mathbf{1 9 7 6 - 8 0}$ & 75.0 & 84.0 & 80.8 & 83.9 & & & & & & \\
$\mathbf{1 9 8 1 - 8 5}$ & 69.2 & 75.3 & 82.8 & & & & & & & \\
$\mathbf{1 9 8 6 - 9 0}$ & 56.0 & 78.9 & & & & & & & &
\end{tabular}

Note: The table shows the percentage of civilian noninstitutionalized men employed full time.

Source: Authors' estimates from the Annual Social and Economic supplement to the Current Population Survey.

Appendix Table 4. Women's Full-Time Employment Rates (\%)

\begin{tabular}{lcccccccccr}
\hline & \multicolumn{10}{c}{ Age } \\
\cline { 2 - 10 } & $\mathbf{2 0 - 2 4}$ & $\mathbf{2 5 - 2 9}$ & $\mathbf{3 0 - 3 4}$ & $\mathbf{3 5 - 3 9}$ & $\mathbf{4 0 - 4 4}$ & $\mathbf{4 5 - 4 9}$ & $\mathbf{5 0 - 5 4}$ & $\mathbf{5 5 - 5 9}$ & $\mathbf{6 0 - 6 4}$ & $\mathbf{6 5 - 6 9}$ \\
\hline $\mathbf{1 9 3 1 - 3 5}$ & & & 34.6 & 40.7 & 42.1 & 49.9 & 47.1 & 40.7 & 25.4 & 8.6 \\
$\mathbf{1 9 3 6 - 4 0}$ & & 36.1 & 37.1 & 43.4 & 51.0 & 54.0 & 52.5 & 45.3 & 27.8 & 12.3 \\
$\mathbf{1 9 4 1 - 4 5}$ & 51.0 & 40.1 & 40.4 & 49.0 & 56.7 & 60.1 & 57.0 & 48.7 & 32.1 & 15.0 \\
$\mathbf{1 9 4 6 - 5 0}$ & 56.3 & 49.6 & 50.4 & 55.0 & 61.9 & 63.2 & 61.4 & 51.5 & 35.4 & 15.8 \\
$\mathbf{1 9 5 1 - 5 5}$ & 57.2 & 55.9 & 54.0 & 59.0 & 62.5 & 65.9 & 60.4 & 51.4 & 36.7 & \\
$\mathbf{1 9 5 6 - 6 0}$ & 60.7 & 57.8 & 58.4 & 59.2 & 63.9 & 63.8 & 57.4 & 54.1 & & \\
$\mathbf{1 9 6 1 - 6 5}$ & 59.0 & 61.7 & 58.4 & 61.7 & 61.1 & 59.1 & 59.4 & & & \\
$\mathbf{1 9 6 6 - 7 0}$ & 59.4 & 61.8 & 62.5 & 59.7 & 59.0 & 60.6 & & & & \\
$\mathbf{1 9 7 1 - 7 5}$ & 56.7 & 66.5 & 59.2 & 57.4 & 60.5 & & & & & \\
$\mathbf{1 9 7 6 - 8 0}$ & 58.8 & 62.1 & 56.8 & 60.2 & & & & & &
\end{tabular}

Note: The table shows the percentage of civilian noninstitutionalized women employed full time.

Source: Authors' estimates from the Annual Social and Economic supplement to the Current Population Survey. 
Appendix Table 5. Men's Median Earnings in Inflation-Adjusted 2015 Dollars, Full-Time Workers, by Age and Birth Cohort

\begin{tabular}{lllllllllll}
\hline & \multicolumn{10}{c}{ Age } \\
\cline { 2 - 10 } & $\mathbf{2 0 - 2 4}$ & $\mathbf{2 5 - 2 9}$ & $\mathbf{3 0 - 3 4}$ & $\mathbf{3 5 - 3 9}$ & $\mathbf{4 0 - 4 4}$ & $\mathbf{4 5 - 4 9}$ & $\mathbf{5 0 - 5 4}$ & $\mathbf{5 5 - 5 9}$ & $\mathbf{6 0 - 6 4}$ & $\mathbf{6 5 - 6 9}$ \\
\hline $\mathbf{1 9 3 1 - 3 5}$ & & & 50,300 & 57,100 & 58,500 & 58,300 & 56,000 & 53,800 & 48,900 & 41,900 \\
$\mathbf{1 9 3 6 - 4 0}$ & & 45,800 & 55,900 & 58,500 & 58,300 & 59,100 & 57,500 & 52,200 & 48,900 & 43,700 \\
$\mathbf{1 9 4 1 - 4 5}$ & 34,300 & 50,200 & 56,700 & 58,300 & 60,500 & 59,400 & 55,300 & 55,900 & 55,500 & 48,100 \\
$\mathbf{1 9 4 6 - 5 0}$ & 37,300 & 47,400 & 52,500 & 57,700 & 58,300 & 58,500 & 62,900 & 59,200 & 55,300 & 54,700 \\
$\mathbf{1 9 5 1 - 5 5}$ & 33,700 & 43,700 & 49,300 & 55,700 & 55,300 & 58,700 & 59,200 & 55,300 & 54,400 & \\
$\mathbf{1 9 5 6 - 6 0}$ & 32,100 & 41,400 & 47,300 & 50,600 & 55,900 & 56,800 & 55,300 & 55,500 & & \\
$\mathbf{1 9 6 1 - 6 5}$ & 28,000 & 39,000 & 44,300 & 53,100 & 54,300 & 55,300 & 55,500 & & & \\
$\mathbf{1 9 6 6 - 7 0}$ & 27,800 & 37,100 & 48,900 & 51,100 & 53,100 & 55,500 & & & & \\
$\mathbf{1 9 7 1 - 7 5}$ & 25,300 & 41,900 & 46,900 & 52,000 & 55,500 & & & & & \\
$\mathbf{1 9 7 6 - 8 0}$ & 28,000 & 37,000 & 44,200 & 50,500 & & & & & & \\
$\mathbf{1 9 8 1 - 8 5}$ & 27,500 & 38,600 & 47,500 & & & & & & & \\
$\mathbf{1 9 8 6 - 9 0}$ & 26,500 & 38,900 & & & & & & & &
\end{tabular}

Note: Estimates are rounded to the nearest $\$ 100$.

Source: Authors' estimates from the Annual Social and Economic supplement to the Current Population Survey.

Appendix Table 6. Women's Median Earnings in Inflation-Adjusted 2015 Dollars, Full-Time Workers, by Age and Birth Cohort

\begin{tabular}{|c|c|c|c|c|c|c|c|c|c|c|}
\hline & \multicolumn{10}{|c|}{ Age } \\
\hline & 20-24 & 25-29 & $30-34$ & 35-39 & $40-44$ & 45-49 & $50-54$ & 55-59 & 60-64 & 65-69 \\
\hline 1931-35 & & & 22,900 & 26,200 & 29,200 & 29,100 & 32,100 & 32,300 & 29,200 & 30,800 \\
\hline $1936-40$ & & 21,400 & 25,700 & 27,400 & 29,100 & 32,300 & 33,400 & 31,600 & 33,600 & 29,600 \\
\hline 1941-45 & 22,000 & 26,100 & 28,700 & 29,100 & 33,400 & 37,100 & 34,900 & 36,300 & 35,800 & 38,700 \\
\hline 1946-50 & 23,700 & 29,200 & 29,600 & 33,600 & 37,100 & 36,400 & 40,500 & 39,500 & 39,800 & 40,400 \\
\hline 1951-55 & 23,500 & 29,100 & 33,600 & 35,300 & 37,900 & 40,500 & 43,200 & 42,000 & 40,400 & \\
\hline 1956-60 & 23,300 & 31,400 & 33,400 & 34,800 & 38,200 & 39,500 & 42,000 & 40,400 & & \\
\hline 1961-65 & 23,400 & 30,600 & 33,200 & 37,700 & 39,500 & 39,800 & 40,400 & & & \\
\hline 1966-70 & 23,300 & 31,600 & 36,300 & 38,900 & 39,800 & 41,100 & & & & \\
\hline 1971-75 & 22,900 & 35,000 & 37,000 & 40,900 & 40,400 & & & & & \\
\hline 1976-80 & 25,200 & 34,000 & 38,700 & 41,200 & & & & & & \\
\hline 1981-85 & 24,700 & 34,300 & 38,600 & & & & & & & \\
\hline 1986-90 & 24,300 & 35,300 & & & & & & & & \\
\hline
\end{tabular}

Note: Estimates are rounded to the nearest $\$ 100$.

Source: Authors' estimates from the Annual Social and Economic supplement to the Current Population Survey. 
Appendix Table 7. Percentage of Full-Time Male Workers Participating in an EmployerSponsored Retirement Plan, by Age and Birth Cohort

\begin{tabular}{|c|c|c|c|c|c|c|c|c|c|c|}
\hline & \multicolumn{10}{|c|}{ Age } \\
\hline & 20-24 & 25-29 & $30-34$ & 35-39 & $40-44$ & 45-49 & 50-54 & 55-59 & 60-64 & 65-69 \\
\hline 1931-35 & & & & & & 63.8 & 62.1 & 56.6 & 52.7 & 37.8 \\
\hline 1936-40 & & & & & 60.2 & 62.1 & 58.8 & 57.5 & 50.6 & 35.6 \\
\hline 1941-45 & & & & 61.0 & 59.4 & 58.5 & 59.2 & 60.1 & 52.9 & 39.7 \\
\hline 1946-50 & & & 57.8 & 59.8 & 58.3 & 60.5 & 61.8 & 56.9 & 53.0 & 34.3 \\
\hline 1951-55 & & 51.8 & 52.6 & 53.9 & 57.1 & 61.5 & 57.6 & 54.2 & 42.2 & \\
\hline 1956-60 & 40.9 & 44.2 & 48.8 & 55.1 & 58.5 & 54.7 & 53.5 & 46.1 & & \\
\hline 1961-65 & 30.7 & 40.6 & 49.2 & 54.9 & 51.7 & 52.6 & 43.4 & & & \\
\hline $1966-70$ & 27.6 & 39.9 & 50.6 & 49.3 & 50.4 & 41.8 & & & & \\
\hline 1971-75 & 28.6 & 43.5 & 45.5 & 48.5 & 40.1 & & & & & \\
\hline $1976-80$ & 31.5 & 35.9 & 43.3 & 38.6 & & & & & & \\
\hline 1981-85 & 26.4 & 37.1 & 35.5 & & & & & & & \\
\hline $1986-90$ & 28.7 & 31.1 & & & & & & & & \\
\hline
\end{tabular}

Source: Authors' estimates from the Annual Social and Economic supplement to the Current Population Survey.

Appendix Table 8. Percentage of Full-Time Female Workers Participating in an EmployerSponsored Retirement Plan, by Age and Birth Cohort

\begin{tabular}{|c|c|c|c|c|c|c|c|c|c|c|}
\hline & \multicolumn{10}{|c|}{ Age } \\
\hline & $20-24$ & 25-29 & $30-34$ & 35-39 & $40-44$ & 45-49 & 50-54 & 55-59 & 60-64 & 65-69 \\
\hline 1931-35 & & & & & & 54.3 & 57.3 & 54.5 & 51.4 & 37.7 \\
\hline 1936-40 & & & & & 54.6 & 54.7 & 54.1 & 55.2 & 55.7 & 38.5 \\
\hline 1941-45 & & & & 51.6 & 54.6 & 55.0 & 59.7 & 59.7 & 53.4 & 44.7 \\
\hline $1946-50$ & & & 52.9 & 53.5 & 55.2 & 59.9 & 63.4 & 61.5 & 55.7 & 42.7 \\
\hline 1951-55 & & 50.9 & 51.9 & 53.9 & 57.1 & 60.2 & 59.8 & 57.5 & 46.6 & \\
\hline 1956-60 & 39.1 & 45.3 & 49.4 & 53.8 & 57.8 & 57.4 & 56.1 & 50.0 & & \\
\hline 1961-65 & 33.3 & 42.3 & 50.8 & 56.0 & 55.9 & 54.3 & 47.3 & & & \\
\hline 1966-70 & 29.2 & 46.2 & 51.7 & 50.8 & 52.5 & 46.2 & & & & \\
\hline 1971-75 & 28.5 & 48.0 & 47.8 & 52.4 & 42.0 & & & & & \\
\hline $1976-80$ & 34.4 & 42.4 & 48.5 & 40.5 & & & & & & \\
\hline 1981-85 & 29.2 & 43.5 & 37.6 & & & & & & & \\
\hline 1986-90 & 30.9 & 32.5 & & & & & & & & \\
\hline
\end{tabular}

Source: Authors' estimates from the Annual Social and Economic supplement to the Current Population Survey. 
Appendix Table 9. Percentage of Men Married, by Age and Birth Cohort

\begin{tabular}{lcccccccccc}
\hline & \multicolumn{10}{c}{ Age } \\
\cline { 2 - 10 } & $\mathbf{2 1 - 2 5}$ & $\mathbf{2 6 - 3 0}$ & $\mathbf{3 1 - 3 5}$ & $\mathbf{3 6 - 4 0}$ & $\mathbf{4 1 - 4 5}$ & $\mathbf{4 6 - 5 0}$ & $\mathbf{5 1 - 5 5}$ & $\mathbf{5 6 - 6 0}$ & $\mathbf{6 1 - 6 5}$ & $\mathbf{6 5 - 7 0}$ \\
\hline $\mathbf{1 9 3 1 - 3 5}$ & & & 86.7 & 87.6 & 84.3 & 83.1 & 82.5 & 79.6 & 80.6 & 80.6 \\
$\mathbf{1 9 3 6 - 4 0}$ & & 80.0 & 84.3 & 84.6 & 80.2 & 80.7 & 79.7 & 80.8 & 77.4 & 76.4 \\
$\mathbf{1 9 4 1 - 4 5}$ & 55.4 & 76.2 & 80.7 & 78.9 & 77.9 & 76.4 & 77.0 & 75.5 & 77.7 & 74.5 \\
$\mathbf{1 9 4 6 - 5 0}$ & 49.5 & 71.0 & 73.9 & 75.8 & 75.1 & 76.4 & 76.0 & 75.1 & 73.8 & 73.8 \\
$\mathbf{1 9 5 1 - 5 5}$ & 42.1 & 61.5 & 67.7 & 69.5 & 69.2 & 71.0 & 70.1 & 70.4 & 71.7 & \\
$\mathbf{1 9 5 6 - 6 0}$ & 34.1 & 54.1 & 62.1 & 66.2 & 70.1 & 68.2 & 69.5 & 68.0 & & \\
$\mathbf{1 9 6 1 - 6 5}$ & 27.4 & 50.3 & 60.3 & 66.6 & 66.4 & 66.5 & 65.9 & & & \\
$\mathbf{1 9 6 6 - 7 0}$ & 22.2 & 46.1 & 61.6 & 65.4 & 65.3 & 64.8 & & & & \\
$\mathbf{1 9 7 1 - 7 5}$ & 20.4 & 45.5 & 60.6 & 65.1 & 66.8 & & & & & \\
$\mathbf{1 9 7 6 - 8 0}$ & 18.8 & 42.0 & 55.8 & 64.1 & & & & & & \\
$\mathbf{1 9 8 1 - 8 5}$ & 15.9 & 36.2 & 51.9 & & & & & & & \\
$\mathbf{1 9 8 6 - 9 0}$ & 12.4 & 32.7 & & & & & & & &
\end{tabular}

Source: Authors' estimates from the Annual Social and Economic supplement to the Current Population Survey.

Appendix Table 10. Percentage of Women Married, by Age and Birth Cohort

\begin{tabular}{lcccccccccc}
\hline & \multicolumn{10}{c}{ Age } \\
\cline { 2 - 11 } & $\mathbf{2 1 - 2 5}$ & $\mathbf{2 6 - 3 0}$ & $\mathbf{3 1 - 3 5}$ & $\mathbf{3 6 - 4 0}$ & $\mathbf{4 1 - 4 5}$ & $\mathbf{4 6 - 5 0}$ & $\mathbf{5 1 - 5 5}$ & $\mathbf{5 6 - 6 0}$ & $\mathbf{6 1 - 6 5}$ & $\mathbf{6 5 - 7 0}$ \\
\hline $\mathbf{1 9 3 1 - 3 5}$ & & & 86.6 & 83.6 & 81.2 & 75.8 & 72.5 & 69.0 & 63.4 & 56.9 \\
$\mathbf{1 9 3 6 - 4 0}$ & & 85.9 & 83.6 & 78.9 & 75.5 & 72.8 & 71.1 & 68.2 & 63.0 & 58.0 \\
$\mathbf{1 9 4 1 - 4 5}$ & 71.5 & 80.6 & 79.0 & 75.9 & 72.0 & 69.3 & 69.6 & 65.0 & 61.8 & 57.2 \\
$\mathbf{1 9 4 6 - 5 0}$ & 64.8 & 75.4 & 72.9 & 72.2 & 70.0 & 69.6 & 66.7 & 64.5 & 61.5 & 57.7 \\
$\mathbf{1 9 5 1 - 5 5}$ & 56.2 & 67.0 & 70.1 & 70.1 & 68.0 & 67.6 & 64.9 & 64.4 & 61.8 & \\
$\mathbf{1 9 5 6 - 6 0}$ & 47.6 & 62.3 & 67.3 & 68.1 & 68.4 & 66.6 & 64.6 & 62.4 & & \\
$\mathbf{1 9 6 1 - 6 5}$ & 43.1 & 59.3 & 65.8 & 68.6 & 65.8 & 64.7 & 63.9 & & & \\
$\mathbf{1 9 6 6 - 7 0}$ & 36.4 & 56.2 & 65.6 & 65.9 & 66.4 & 65.6 & & & & \\
$\mathbf{1 9 7 1 - 7 5}$ & 31.9 & 54.6 & 65.3 & 63.9 & 64.9 & & & & & \\
$\mathbf{1 9 7 6 - 8 0}$ & 29.9 & 53.0 & 61.6 & 64.7 & & & & & & \\
$\mathbf{1 9 8 1 - 8 5}$ & 26.6 & 47.1 & 58.1 & & & & & & \\
$\mathbf{1 9 8 6 - 9 0}$ & 20.5 & 42.2 & & & & & & & \\
\hline
\end{tabular}

Source: Authors' estimates from the Annual Social and Economic supplement to the Current Population Survey. 
Appendix Table 11. Percentage of Adults Who Own a Home, by Age and Birth Cohort

\begin{tabular}{lcccccccccc}
\hline & \multicolumn{10}{c}{ Age } \\
\cline { 2 - 10 } & $\mathbf{2 1 - 2 5}$ & $\mathbf{2 6 - 3 0}$ & $\mathbf{3 1 - 3 5}$ & $\mathbf{3 6 - 4 0}$ & $\mathbf{4 1 - 4 5}$ & $\mathbf{4 6 - 5 0}$ & $\mathbf{5 1 - 5 5}$ & $\mathbf{5 6 - 6 0}$ & $\mathbf{6 1 - 6 5}$ & $\mathbf{6 5 - 7 0}$ \\
\hline $\mathbf{1 9 3 1 - 3 5}$ & & & & & 75.0 & 79.2 & 79.6 & 78.6 & 80.7 & 80.8 \\
$\mathbf{1 9 3 6 - 4 0}$ & & & & 71.5 & 76.7 & 75.0 & 76.8 & 78.4 & 78.3 & 78.1 \\
$\mathbf{1 9 4 1 - 4 5}$ & & & 65.4 & 73.4 & 70.5 & 73.6 & 75.8 & 77.2 & 79.6 & 78.8 \\
$\mathbf{1 9 4 6 - 5 0}$ & & 49.1 & 64.3 & 66.1 & 69.3 & 73.1 & 75.9 & 78.0 & 77.1 & 76.8 \\
$\mathbf{1 9 5 1 - 5 5}$ & 20.4 & 47.6 & 55.2 & 62.4 & 66.6 & 72.0 & 73.0 & 75.0 & 73.8 & \\
$\mathbf{1 9 5 6 - 6 0}$ & 21.4 & 38.0 & 51.5 & 60.5 & 68.9 & 70.4 & 70.5 & 71.8 & & \\
$\mathbf{1 9 6 1 - 6 5}$ & 15.0 & 33.9 & 51.5 & 62.7 & 66.8 & 66.4 & 67.3 & & & \\
$\mathbf{1 9 6 6 - 7 0}$ & 11.9 & 33.7 & 53.8 & 62.0 & 63.2 & 61.6 & & & & \\
$\mathbf{1 9 7 1 - 7 5}$ & 11.3 & 35.0 & 53.3 & 55.8 & 58.5 & & & & & \\
$\mathbf{1 9 7 6 - 8 0}$ & 13.0 & 35.2 & 45.6 & 51.4 & & & & & & \\
$\mathbf{1 9 8 1 - 8 5}$ & 12.9 & 28.4 & 40.6 & & & & & & & \\
$\mathbf{1 9 8 6 - 9 0}$ & 8.9 & 24.3 & & & & & & & &
\end{tabular}

Source: Authors' estimates from the Annual Social and Economic supplement to the Current Population Survey.

Appendix Table 12. Median per Capita Inflation-Adjusted Household Net Worth by Age and Birth Cohort (\$)

\begin{tabular}{|c|c|c|c|c|c|c|c|c|c|c|}
\hline & \multicolumn{10}{|c|}{ Age } \\
\hline & 26-31 & $32-37$ & $38-43$ & $44-49$ & 50-55 & $56-61$ & 62-67 & $68-73$ & 74-79 & 80-85 \\
\hline 1928-33 & & & & & & 119,100 & 121,500 & 169,100 & 151,900 & 146,800 \\
\hline 1934-39 & & & & & 123,500 & 127,100 & 160,900 & 167,200 & 132,500 & \\
\hline 1940-45 & & & & 96,500 & 119,600 & 197,600 & 198,500 & 167,300 & & \\
\hline 1946-51 & & & 74,500 & 81,200 & 140,300 & 199,800 & 162,500 & & & \\
\hline 1952-57 & & 45,900 & 55,400 & 108,500 & 167,700 & 120,300 & & & & \\
\hline 1958-63 & 16,500 & 38,400 & 79,900 & 114,000 & 95,200 & & & & & \\
\hline 1964-69 & 19,000 & 39,100 & 86,900 & 64,100 & & & & & & \\
\hline 1970-75 & 20,300 & 43,300 & 43,000 & & & & & & & \\
\hline 1976-81 & 16,400 & 21,600 & & & & & & & & \\
\hline 1982-87 & 9,500 & & & & & & & & & \\
\hline
\end{tabular}

Note: Estimates are reported in inflation-adjusted 2015 dollars, rounded to the nearest hundred dollars. The analysis divided total household new worth by two for married adults.

Source: Authors' estimates from the Survey of Consumer Finances, 1983-2013. 
Appendix Table 13. Percentage of Adults with Financial Assets, by Age and Birth Cohort

\begin{tabular}{|c|c|c|c|c|c|c|c|c|c|c|}
\hline & \multicolumn{10}{|c|}{ Age } \\
\hline & 26-31 & $32-37$ & $38-43$ & $44-49$ & $50-55$ & $56-61$ & $62-67$ & 68-73 & 74-79 & 80-85 \\
\hline 1928-33 & & & & & & 90.4 & 91.5 & 96.2 & 99.7 & 97.6 \\
\hline 1934-39 & & & & & 93.1 & 93.6 & 93.9 & 97.0 & 98.1 & \\
\hline 1940-45 & & & & 92.4 & 93.2 & 97.0 & 97.5 & 97.6 & & \\
\hline 1946-51 & & & 92.1 & 94.3 & 95.5 & 97.8 & 98.3 & & & \\
\hline 1952-57 & & 92.1 & 93.6 & 95.3 & 96.6 & 96.2 & & & & \\
\hline 1958-63 & 86.3 & 93.0 & 94.4 & 94.0 & 94.3 & & & & & \\
\hline 1964-69 & 90.7 & 94.4 & 93.8 & 95.3 & & & & & & \\
\hline $1970-75$ & 93.1 & 94.1 & 94.4 & & & & & & & \\
\hline 1976-81 & 91.2 & 93.8 & & & & & & & & \\
\hline 1982-87 & 94.0 & & & & & & & & & \\
\hline
\end{tabular}

Note: Estimates include retirement accounts.

Source: Authors' estimates from the Survey of Consumer Finances, 1983-2013.

Appendix Table 14. Median per Capita Inflation-Adjusted Value of Household Financial Assets for Adults with Positive Holdings, by Age and Birth Cohort (\$)

\begin{tabular}{|c|c|c|c|c|c|c|c|c|c|c|}
\hline & \multicolumn{10}{|c|}{ Age } \\
\hline & $26-31$ & $32-37$ & $38-43$ & 44-49 & 50-55 & $56-61$ & $62-67$ & $68-73$ & 74-79 & 80-85 \\
\hline 1928-33 & & & & & & 34,200 & 37,900 & 54,000 & 32,900 & 27,300 \\
\hline 1934-39 & & & & & 27,000 & 40,000 & 60,000 & 44,500 & 35,100 & \\
\hline $1940-45$ & & & & 17,800 & 29,800 & 60,200 & 55,200 & 50,500 & & \\
\hline 1946-51 & & & 16,300 & 22,400 & 53,400 & 65,300 & 52,000 & & & \\
\hline 1952-57 & & 10,400 & 17,400 & 36,900 & 54,400 & 40,100 & & & & \\
\hline 1958-63 & 5,100 & 11,000 & 29,700 & 32,700 & 31,700 & & & & & \\
\hline 1964-69 & 8,300 & 15,300 & 24,100 & 22,000 & & & & & & \\
\hline $1970-75$ & 7,600 & 11,600 & 17,900 & & & & & & & \\
\hline 1976-81 & 7,200 & 10,800 & & & & & & & & \\
\hline 1982-87 & 4,900 & & & & & & & & & \\
\hline
\end{tabular}

Note: Estimates are reported in inflation-adjusted 2015 dollars, rounded to the nearest hundred dollars, and include the value of retirement accounts. The analysis divided the value of household financial assets by two for married adults.

Source: Authors’ estimates from the Survey of Consumer Finances, 1983-2013. 
Appendix Table 15. Percentage of Adults with a Retirement Account, by Age and Birth Cohort

\begin{tabular}{|c|c|c|c|c|c|c|c|c|c|c|}
\hline & \multicolumn{10}{|c|}{ Age } \\
\hline & 26-31 & $32-37$ & $38-43$ & $44-49$ & $50-55$ & $56-61$ & $62-67$ & 68-73 & 74-79 & 80-85 \\
\hline 1928-33 & & & & & & 54.9 & 45.0 & 43.9 & 38.2 & 30.8 \\
\hline 1934-39 & & & & & 54.3 & 57.1 & 51.7 & 51.7 & 34.2 & \\
\hline $1940-45$ & & & & 51.5 & 58.6 & 67.4 & 54.8 & 48.4 & & \\
\hline 1946-51 & & & 56.4 & 57.4 & 67.8 & 68.0 & 56.5 & & & \\
\hline 1952-57 & & 47.1 & 60.0 & 65.3 & 70.4 & 62.9 & & & & \\
\hline 1958-63 & 34.8 & 56.7 & 66.8 & 65.5 & 61.3 & & & & & \\
\hline 1964-69 & 51.0 & 61.1 & 63.1 & 61.4 & & & & & & \\
\hline 1970-75 & 54.2 & 57.3 & 60.2 & & & & & & & \\
\hline 1976-81 & 49.0 & 54.7 & & & & & & & & \\
\hline 1982-87 & 47.3 & & & & & & & & & \\
\hline
\end{tabular}

Source: Authors’ estimates from the Survey of Consumer Finances, 1983-2013.

Appendix Table 16. Median per Capita Inflation-Adjusted Value of Household Retirement Accounts for Accountholders, by Age and Birth Cohort (\$)

\begin{tabular}{|c|c|c|c|c|c|c|c|c|c|c|}
\hline & & & & & A & & & & & \\
\hline & 26-31 & $32-37$ & $38-43$ & 44-49 & 50-55 & $56-61$ & $62-67$ & 68-73 & 74-79 & 80-85 \\
\hline 1928-33 & & & & & & 24,900 & 33,600 & 45,900 & 33,500 & 40,900 \\
\hline 1934-39 & & & & & 26,800 & 27,400 & 72,900 & 43,900 & 81,800 & \\
\hline $1940-45$ & & & & 14,900 & 25,000 & 37,800 & 78,000 & 86,400 & & \\
\hline 1946-51 & & & 11,500 & 25,000 & 47,300 & 76,300 & 86,900 & & & \\
\hline 1952-57 & & 7,600 & 15,600 & 33,800 & 56,100 & 65,400 & & & & \\
\hline 1958-63 & 3,800 & 9,800 & 24,000 & 43,300 & 61,300 & & & & & \\
\hline 1964-69 & 5,500 & 14,900 & 29,000 & 42,800 & & & & & & \\
\hline 1970-75 & 6,800 & 13,900 & 30,000 & & & & & & & \\
\hline 1976-81 & 8,500 & 18,500 & & & & & & & & \\
\hline 1982-87 & 8,000 & & & & & & & & & \\
\hline
\end{tabular}

Note: Estimates are reported in inflation-adjusted 2015 dollars, rounded to the nearest hundred dollars. The analysis divided the value of household retirement accounts by two for married adults.

Source: Authors' estimates from the Survey of Consumer Finances, 1983-2013. 
Appendix Table 17. Percentage of Adults with Housing Wealth, by Age and Birth Cohort

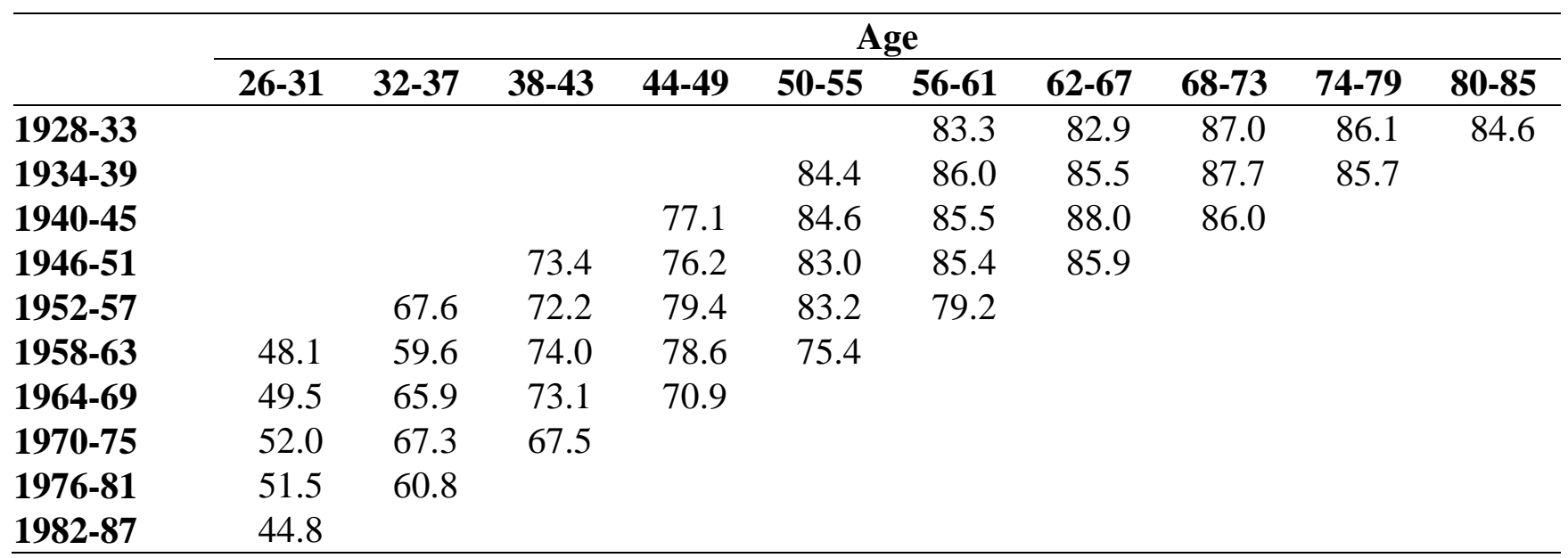

Note: Estimates refer to gross housing wealth. Net housing wealth, or home equity, was negative for people whose housing debt exceeded their housing wealth.

Source: Authors' estimates from the Survey of Consumer Finances, 1983-2013.

Appendix Table 18. Median per Capita Inflation-Adjusted Housing Wealth for Adults with Housing Wealth, by Age and Birth Cohort (\$)

\begin{tabular}{|c|c|c|c|c|c|c|c|c|c|c|}
\hline & \multicolumn{10}{|c|}{ Age } \\
\hline & $26-31$ & $32-37$ & $38-43$ & 44-49 & 50-55 & 56-61 & $62-67$ & 68-73 & 74-79 & 80-85 \\
\hline 1928-33 & & & & & & 73,600 & 92,000 & 132,900 & 168,600 & 153,300 \\
\hline 1934-39 & & & & & 86,900 & 91,000 & 132,900 & 173,700 & 184,000 & \\
\hline $1940-45$ & & & & 81,800 & 102,200 & 153,300 & 235,100 & 184,000 & & \\
\hline 1946-51 & & & 102,200 & 115,500 & 145,100 & 251,400 & 194,200 & & & \\
\hline 1952-57 & & 75,600 & 100,200 & 143,100 & 255,500 & 194,200 & & & & \\
\hline 1958-63 & 66,400 & 100,200 & 143,100 & 235,100 & 204,400 & & & & & \\
\hline 1964-69 & 86,900 & 117,500 & 245,300 & 189,100 & & & & & & \\
\hline 1970-75 & 102,200 & 202,400 & 204,400 & & & & & & & \\
\hline 1976-81 & 204,400 & 166,600 & & & & & & & & \\
\hline 1982-87 & 153,300 & & & & & & & & & \\
\hline
\end{tabular}

Note: Estimates are reported in inflation-adjusted 2015 dollars, rounded to the nearest hundred dollars. The analysis divided the value of housing wealth by two for married adults. Estimates refer to gross housing wealth. Net housing wealth, or home equity, was negative for people whose housing debt exceeded their housing wealth. Source: Authors' estimates from the Survey of Consumer Finances, 1983-2013. 
Appendix Table 19. Percentage of Adults with Outstanding Debt, by Age and Birth Cohort

\begin{tabular}{|c|c|c|c|c|c|c|c|c|c|c|}
\hline & \multicolumn{10}{|c|}{ Age } \\
\hline & 26-31 & $32-37$ & $38-43$ & 44-49 & $50-55$ & 56-61 & 62-67 & $68-73$ & 74-79 & 80-85 \\
\hline 1928-33 & & & & & & 75.5 & 64.3 & 54.4 & 47.2 & 37.3 \\
\hline 1934-39 & & & & & 87.4 & 73.9 & 68.3 & 61.7 & 54.0 & \\
\hline 1940-45 & & & & 88.2 & 84.3 & 76.0 & 75.6 & 63.9 & & \\
\hline 1946-51 & & & 90.7 & 87.4 & 83.2 & 82.4 & 74.3 & & & \\
\hline 1952-57 & & 88.7 & 87.8 & 88.1 & 88.6 & 81.2 & & & & \\
\hline 1958-63 & 87.2 & 89.9 & 90.5 & 87.9 & 82.3 & & & & & \\
\hline 1964-69 & 86.6 & 89.1 & 87.3 & 87.3 & & & & & & \\
\hline $1970-75$ & 86.4 & 88.8 & 85.9 & & & & & & & \\
\hline 1976-81 & 88.7 & 85.6 & & & & & & & & \\
\hline 1982-87 & 80.9 & & & & & & & & & \\
\hline
\end{tabular}

Source: Authors’ estimates from the Survey of Consumer Finances, 1983-2013.

Appendix Table 20. Median per Capita Inflation-Adjusted Value of Outstanding Debt for Debtholders, by Age and Birth Cohort (\$)

\begin{tabular}{|c|c|c|c|c|c|c|c|c|c|c|}
\hline & \multicolumn{10}{|c|}{ Age } \\
\hline & $26-31$ & $32-37$ & $38-43$ & $44-49$ & 50-55 & $56-61$ & $62-67$ & 68-73 & 74-79 & $80-85$ \\
\hline 1928-33 & & & & & & 10,500 & 9,400 & 13,200 & 17,700 & 25,500 \\
\hline 1934-39 & & & & & 19,100 & 20,500 & 13,500 & 19,400 & 15,900 & \\
\hline $1940-45$ & & & & 26,800 & 34,900 & 26,300 & 38,700 & 24,500 & & \\
\hline 1946-51 & & & 38,500 & 39,000 & 41,200 & 50,600 & 34,700 & & & \\
\hline 1952-57 & & 33,800 & 39,900 & 50,900 & 63,600 & 46,500 & & & & \\
\hline 1958-63 & 16,300 & 35,400 & 54,100 & 69,900 & 58,800 & & & & & \\
\hline 1964-69 & 23,600 & 49,200 & 77,500 & 59,300 & & & & & & \\
\hline $1970-75$ & 35,500 & 72,200 & 65,900 & & & & & & & \\
\hline 1976-81 & 40,500 & 63,100 & & & & & & & & \\
\hline 1982-87 & 30,700 & & & & & & & & & \\
\hline
\end{tabular}

Note: Estimates are reported in inflation-adjusted 2015 dollars, rounded to the nearest hundred dollars. The analysis divided the value of household debt by two for married adults.

Source: Authors' estimates from the Survey of Consumer Finances, 1983-2013. 


\section{RECENT WORKING PAPERS FROM THE CENTER FOR RETIREMENT RESEARCH AT BOSTON COLLEGE}

Mom and Dad We're Broke, Can You Help? A Comparative Study of Financial Transfers Within Families Before and After the Great Recession Mary K. Hamman, Daniela Hochfellner, and Pia Homrighausen, November 2017

Homeownership, Social Insurance, and Old-Age Security in the United States and Europe Stipica Mudrazija and Barbara A. Butrica, October 2017

How Much Does Motherhood Cost Women in Social Security Benefits? Matthew S. Rutledge, Alice Zulkarnain, and Sara Ellen King, October 2017

How Much Does Out-of-Pocket Medical Spending Eat Away at Retirement Income? Melissa McInerney, Matthew S. Rutledge and Sara Ellen King, October 2017

Can Knowledge Empower Women to Save More for Retirement? Drew M. Anderson and J. Michael Collins, September 2017

Dementia, Help with Financial Management, and Well-Being Anek Belbase and Geoffrey T. Sanzenbacher, September 2017

The Behavioral and Consumption Effects of Social Security Changes Wenliang Hou and Geoffrey T. Sanzenbacher, September 2017

Family Transfers With Retirement-Aged Adults in the United States: Kin Availability, Wealth Differentials, Geographic Proximity, Gender, and Racial Disparities Ashton M. Verdery, Jonathan Daw, Colin Campbell, and Rachel Margolis, August 2017

Guardianship and the Representative Payee Program Anek Belbase and Geoffrey T. Sanzenbacher, August 2017

The Relative Effects of Economic and Non-Economic Factors on Taxpayers' Preferences Between Front-Loaded and Back-Loaded Retirement Savings Plans Andrew D. Cuccia, Marcus M. Doxey, and Shane R. Stinson, July 2017

Social Security and Total Replacement Rates in Disability and Retirement Mashfiqur R. Khan, Matthew S. Rutledge, and Geoffrey T. Sanzenbacher, May 2017

An Experimental Analysis of Modifications to the Survivor Benefit Information within the Social Security Statement Jeffrey Diebold and Susan Camilleri, May 2017

All working papers are available on the Center for Retirement Research website (http://crr.bc.edu) and can be requested by e-mail (crr@bc.edu) or phone (617-552-1762). 